Portland State University

PDXScholar

$1-1-2012$

\title{
"We Were Privileged in Oregon": Jessie Laird Brodie and Reproductive Politics, Locally and Transnationally, 1915-1975
}

Sadie Anne Adams

Portland State University

Follow this and additional works at: https://pdxscholar.library.pdx.edu/open_access_etds Let us know how access to this document benefits you.

\section{Recommended Citation}

Adams, Sadie Anne, "'We Were Privileged in Oregon": Jessie Laird Brodie and Reproductive Politics, Locally and Transnationally, 1915-1975" (2012). Dissertations and Theses. Paper 781.

https://doi.org/10.15760/etd.781

This Thesis is brought to you for free and open access. It has been accepted for inclusion in Dissertations and Theses by an authorized administrator of PDXScholar. Please contact us if we can make this document more accessible: pdxscholar@pdx.edu. 
"We Were Privileged in Oregon":

Jessie Laird Brodie and Reproductive Politics, Locally and Transnationally, 1915-1975

by

Sadie Anne Adams

A thesis submitted in partial fulfillment of the requirements for the degree of

Master of Arts

in

History

Thesis Committee:

Patricia Schechter, Chair

Friedrich Schuler

Tim Garrison

Melody Rose

Rickie Solinger

Portland State University

(C)2012 


\begin{abstract}
This thesis conveys the history of reproductive politics in Oregon through the life of Dr. Jessie Laird Brodie (1898-1990). Brodie was a key figure in this history from the 1930's until the 1970's, mainly through the establishment of family planning programs through social and medical channels in Oregon and throughout Latin America. Oregon's reproductive legislation walked a fine line between conservatism and progressivism, but in general supported reproductive healthcare as a whole in comparison to the rest of the United States and Latin America. The state passed controversial contraceptive legislation in 1935 that benefited public health, but also passed eugenic laws, specifically a 1938 marriage bill, that attempted to limit specific population's reproductive control. By the time family planning was solidly rooted in the national and international sociopolitical discourse in the 1960's, due to the advent of the "pill," population control rhetoric, and the Griswold v. Connecticut (1965) Supreme Court decision, eugenic laws were virtually obsolete. Portland's history suggests that leaders in local reproductive politics sought to appeal to a diverse clientele but were restricted to the confines of federal funding mandates, specifically the war on poverty, that were fueled by postwar liberalism in an increasingly global age.

The first chapter concentrates on the history of women's health and reproduction in Oregon prior to the 1960's. Dr. Jessie Laird Brodie's experiences with families in poverty during medical school in the 1920's disheartened her and motivated her to seek ways for these women to efficiently and affordably access birth control information. In response to public health concerns, she helped get positive contraception legislation
\end{abstract}


passed in Oregon in the 1930's that set guidelines and restrictions for manufacture of contraceptives. This law was the first of its kind in the country and set a precedent for other states to follow. Brodie also supported a marriage bill in the 1930's that mandated premarital syphilis and psychological testing, in the hopes that it would lead couples to seek contraceptive, or "hygienic," advice from their physicians as efforts to establish a birth control clinic had failed up to this point.

The second chapter focuses on Brodie's continued involvement in Oregon in the 1940 's and 1950 's, a period marked by a high tide of pronatalism in the U.S., and how she took Oregon's vision for women to a national and international level. Locally, she was involved with the E.C. Brown Trust, an organization dedicated to sex education, and was the President for the Pacific Northwest Conference on Family Relations, a group focused on the postwar family adjustments of higher divorce rates and juvenile delinquency. In 1947, Brodie was one of the founding members of the Pan-American Medical Women's Alliance, an organization created to provide a professional arena for women physicians throughout the Americas to discuss problems specific to women and children. Involvement with these groups helped her gain recognition nationally and in the late 1950's she served as President, and then Executive Director, of the American Medical Women's Association.

Lastly, the third chapter looks at the establishment and growth of Planned Parenthood Association of Oregon (PPAO) in the 1960's under Brodie's leadership and her foray into the international establishment of family planning programs through the Boston-based Pathfinder Fund, an organization whose mission involved bringing 
effective reproductive healthcare to developing countries. Brodie acted as Executive Director for PPAO, where she was able to use her medical expertise and connections to bring the new organization credibility and respect throughout Oregon that they lacked before her involvement because the board was mainly comprised of a younger generation on the brink of second-wave feminism and the sexual revolution. In her career with Pathfinder she assessed the needs for family planning in Latin American and Caribbean countries and facilitated the establishment of programs in the region, largely in cooperation with the U.S. federal government and the Population Council.

The conclusion offers a brief history of Dr. Brodie's continued involvement in the local and international communities beyond 1975 and the awards she received highlighting her career in the battle for effective healthcare for all women.

In short, this thesis argues that legal and rights-based contestations that were prevalent in other regions of the U.S. and throughout the world were not characteristic of Oregon, allowing Brodie and PPAO to bring birth control to the state with relatively limited opposition. 


\section{For my Mama,}

who told me I could do anything I put my mind to and always provided me with the love and support to do just that. 


\section{ACKNOWLEGDEMENTS}

This thesis would have been impossible for me to complete without the support of many wonderful people. I am immensely grateful to my adviser, Professor Patricia Schechter, for sticking with me through this extremely long process and its many educational detours. The advice and support she provided as I researched and wrote this thesis was amazing, and I cannot fully express my appreciation, especially over the last couple of months. I also want to thank her for challenging me at every point along my journey through this M.A. program, as it has helped me become a better student, teacher, and in many ways a stronger person.

I am incredibly thankful to Professor Friedrich Schuler for encouraging me, as an undergraduate, to: "Make something of your talent!" His comments inspired me to enroll in graduate school in the first place. I also appreciate his continued support despite the long process that this journey has become.

In addition, I would like to thank Professor Tim Garrison, for providing me the legal background I needed to wade through so many documents. The content from his Constitutional History classes has been invaluable throughout the research and writing of this thesis.

The Oregon Historical Society was the jumping off point for this thesis and I owe a thank you to Micki Tint, for helping me access Planned Parenthood of Oregon's oral histories and for allowing me to re-transcribe them so that I could use them in my thesis. 
Samantha Garza, of Planned Parenthood of the Columbia/Willamette (PPCW), deserves a great deal of thanks for coordinating and helping me access the archived documents of Planned Parenthood Association of Oregon and for letting me come sift through them weekly for five months. I would also like to thank PPCW's President, David Greenberg, for allowing me access to Planned Parenthood's historical documents. Every bit of help was appreciated and this thesis would not have been possible without it.

An enormous thank you to Matt Herbison, and the rest of the staff in the Legacy Center at Drexel University College of Medicine, for quickly allowing me access Jessie Laird Brodie's papers and for the help sifting through the plethora of information. Their facility and their staff are amazing! My whirlwind trip would have been impossible without the help all of them provided.

To Heather Thompson, Jonathan Wells, and their entire family, thank you so much for giving a complete stranger a warm welcome and an extremely comfortable place to stay on such short notice. My gratitude is impossible to fully express and I hope one day we meet again.

A few more local thanks go to: Michelle Hammond at the Catholic Sentinel, for giving me access to the newspaper and for helping me make some ridiculously creative and essential copies; Terry Baxter at Multnomah County Voter Registration; Steve Kindred at Clackamas County Elections; and to the awesome Interlibrary Loan department at Portland State University.

To my family, there are so many of you, but this is an all-encompassing, THANK YOU, for listening to me talk about my thesis for the last seven years, for continuing to 
believe that I could get it done, and for being understanding about my unavailability for the last several months of writing. I am the luckiest girl in the world to have so many people who support and love me. You are all amazing.

Finally, I am eternally grateful to Steve, for putting up with me at my best and at my worst, supporting me through every bit of this process, and for keeping our house inhabitable while I destroyed it. But, most importantly, thank you for making me laugh every single day. I could not have made it through this without you. 


\section{TABLE OF CONTENTS}

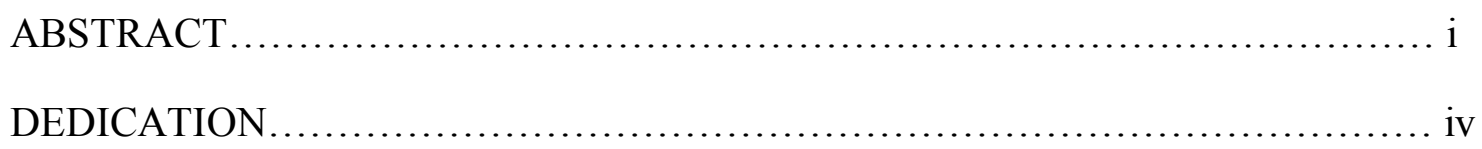

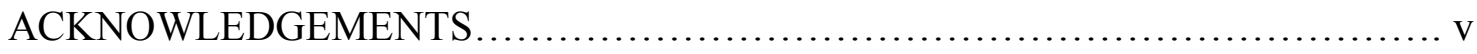

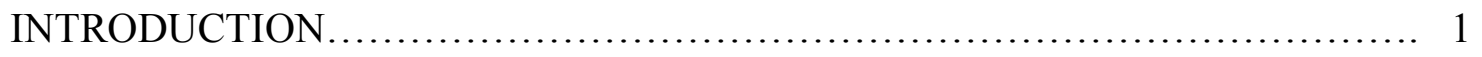

CHAPTER 1

"We Were Privileged in Oregon...": A Pragmatic Approach to Reproductive Politics................................................................... 20

CHAPTER 2

"Service Unlimited": Representing Oregon Nationally and Internationally........... 55

CHAPTER 3

“An Idea Whose Time Has Come... ”: Planned Parenthood in Oregon and Family

Planning in Latin America, 1963-1975........................................ 95

CONCLUSION ...................................................... 150

BIBLIOGRAPHY .................................................... 157 


\section{INTRODUCTION}

The history of reproductive politics in the United States as a whole has been well documented over the last two decades by numerous historians. They have approached the subject from social, political, and scientific perspectives, and some have even ventured into the transnational story. In documenting this history, historians have focused mainly on the eastern region of the U.S. or on specific key players, including birth control leaders, most notably Margaret Sanger, or corporations, such as Planned Parenthood. Many of the defining studies, such as Linda Gordon's The Moral Property of Women: A History of Birth Control Politics in America, drew deep political energy and urgency from the women's movement of the 1970s. Gordon's study has been particularly influential in the field of women's history, putting American birth control politics into a feminist historical context. Subsequent treatments of reproductive political history in the U.S. have maintained and built upon the feminist standpoint presented in that history and emphasize social and political movements focused on women's rights as the main engines of change. In part, this study seeks to remedy the traditional focus on the east coast, charismatic leaders, and the change process focused in the courts and state legislatures. I do this by emphasizing Oregon's unique situation of having few legal or social barriers in their efforts to bring birth control to the state.

Historians of reproductive politics in the 1980s, like those before them, had one eye keenly focused on the general backlash against feminism in that decade and in particular against abortion rights won in 1973 in the landmark decision Roe v. Wade. 
These studies offered useful insights for my approach because they often drew from the national and Supreme Court grand narrative to put local histories in context with the larger historical picture. Using the approaches of social and oral history, studies like David Cline's, Creating Choice: A Community Responds to the Need for Abortion and Birth Control, 1961-1973, and Tom Davis', Sacred Work: Planned Parenthood and Its Clergy Alliances, have painted an increasingly comprehensive picture of the birth control struggle at the local level, and restored a wider array of characters to the stage especially the clergy members and physicians that were an integral part of the movement in their respective communities. Indeed, this study was originally conceived as a comparative analysis between Catholic and Jewish institutions and opinion shapers on the issue of reproductive politics and abortion, specifically in Portland. However, in digging deeper in to the Oregon story, a number of issues emerged that forced me to reframe my questions and my story to better capture the particular social, political, and cultural fabric of the Pacific Northwest, one not well integrated into any of the existing literatures in women's history. I had to focus on the relatively uncontested nature of the movement locally, because Portland is not just "another" big urban center that can be directly and fairly compared to cities on the east coast, but is historically a progressive arena where citizens thrive and insist on maintaining Oregon's identity as a pioneer western state. In other words, specific frameworks salient to Oregon women's history, specifically the notion of Oregon exceptionalism, were an essential ingredient for telling this story in all its power and particularity. 
Oregon's history in the realm of U.S. reproductive politics is essentially invisible, but has received sporadic attention from local and national scholars, though nothing approaching a comprehensive account of how birth control politics impacted the state. Rickie Solinger's book, The Abortionist: A Woman Against the Law, takes a close look at the abortion industry on the west coast, specifically in Portland, where Dr. Ruth Barnett had a thriving abortion practice, along with several others, during the first half of the twentieth century, but does not directly address the birth control movement. Instead, Solinger addresses abortion laws in effect during the illegal era, arguing that enforcement of these laws was more detrimental to women than abortion practitioners. Solinger's history of Barnett is not intended to be a distinctly Oregon story, though it does provide a detailed portrait of a specific arena of Portland's vice, but Barnett's story is used as a vehicle to exemplify the abortion industry and dangers for women as a result of antiabortion laws in the U.S. prior to the abortion raids in the 1950's and Roe v. Wade in 1973.

Locally, a series of oral histories were conducted in the late 1970's, in coordination with the Oregon Historical Society, with four founding members of the Planned Parenthood Association of Oregon, but they were restricted for a time and appear to have received little attention before the research done for this thesis. Beyond these oral histories and Solinger's study of Barnett, Oregon's imprint on national birth control history is virtually absent. Nor does it fit into traditional birth control histories that emphasize the intense political and social conflicts that historians tend to refer to when structuring similar history in other urban locations. This thesis seeks to put Oregon's 
active reproductive political history into the record by focusing on the life of Dr. Jessie Laird Brodie (1898-1990) and her contributions to the birth control movement in Oregon. Brodie's story presents what I argue is a representative view of Oregon's unique sociopolitical culture, and offers an especially enriching story of reproductive politics before Roe that has not been told before.

Born in Detroit, Michigan in 1898, Jessie Laird's family migrated west in 1903, where she grew up as the daughter of a country physician in Lebanon, Oregon. In her autobiography, Brodie stated that she had "no memory of a time when I did not plan to be a physician," and recalled fondly that she sometimes assisted her father with emergency surgeries and dressed her dolls in bandages rather than clothes. ${ }^{1}$ In her account, Brodie reminds us of the high place of medicine in the first wave of feminism, which produced in 1920 a higher percentage of women physicians than at any time in U.S. history until the 1970's, when second wave feminism and affirmative action contributed to the significant increase in women's admission to medical school.

Crucial to Brodie's interpretation of her career as a woman physician, however, is not the credit to feminism or activism, but the folkloric equality supposedly enjoyed by white men and women of the pioneer west. During her childhood she recalled going through "all the stages of pioneer development," leaving the notion of the "pioneer spirit" as a lasting influence on Brodie's outlook on life, particularly in her views on the equality between women and men in Oregon. ${ }^{2}$ She iterated that she was not discriminated as a woman in Oregon as opposed to the East Coast where she felt that discrimination toward

\footnotetext{
${ }^{1}$ Jessie Laird Brodie, M.D., "Dr. Jessie”: The Odyssey of a Woman Physician (Portland: Carolina Pacific Publishing, 1991), 7.

${ }^{2}$ Brodie, Dr. Jessie, 14.
} 
women was "much more prominent." That is, Brodie imbibed and consistently

reflected, and indeed, naturalized, the notion of gender equality as an inherent part of her identity as a westerner and as an authentic part of Oregon culture, in a way that helped her enormously advance her extraordinary career over seven decades. In other words, not activism or a pointed bid for empowerment but the assumption of "natural equality" allowed Brodie to successfully, though gently, disarm critics at crucial points in her career. In a sharp break with the nineteenth century strategies of Abigail Scott Duniway in the suffrage effort, who argued that the pioneer wife was among the most exploited members of the settler colonial community, Brodie believed, rather like Dr. Esther Pohl Lovejoy, who inherited and rewrote the suffrage strategy for the 1912 state referendum victory, equality was for "everyone" and a natural unthreatening part of Oregon political culture, an outlook that both of these women physicians relied on in their later national and transnational medical work. ${ }^{4}$

In addition to naturalizing and updating the myth of gender equality in the pioneer culture of Oregon white settlers, Brodie further attributed this equality to the fact that in Oregon the schools were coeducational which helped "make a better relationship between men and women," especially when moving on to higher education. ${ }^{5}$ In this interpretation of Oregon women's experience, a kind of commonsense, non-threatening notion of

\footnotetext{
${ }^{3}$ Dr. Jessie Laird Brodie, interview by Roberta Watts, Oregon Historical Society, February 14 and March 29, 1978, 9.

${ }^{4}$ Kimberly Jensen, "Feminist Transnational Activism and International Health: The Medical Women's International Association and the American Women's Hospitals, 1919-1948," in Women and Transnational Activism in Historical Perspective, eds. Kimberly Jensen and Erika Kuhlman (Dordrecht: Republic of Letters, 2010), 146-148; Letter from Esther Pohl Lovejoy, 11/2/56, Jessie Laird Brodie Papers, Box 5, "Brodie, J.L., President, June 1959-June 1960" folder, Legacy Center, Drexel University College of Medicine (hereafter JLB Papers).

${ }^{5}$ Brodie, OHS Interview, 1978, 9.
} 
women as competent students side by side with men and boys came to the fore, as did the approval and encouragement of her own father, who after initial discontentment with Brodie's decision to pursue medicine, viewed her success with pride and respect. By naturalizing female intellectual and professional achievement within the normative common school experience and highlighting the approval of a father figure, Brodie mobilized a kind of upbeat American optimism and commonsense rather than acknowledging the complexities of gender socialization and gender tension, so prevalent to her generation, as central to her own story. This approach also helped her to neatly silence the question of female ambition and competition with men. When she was fifteen the Laird family moved to North Portland, where Jessie completed her last three years of schooling at Jefferson High School and then went on to Reed college, where she studied biology in preparation for teaching or medical school. Her relatively privileged upbringing and the high expectations set by her parents allowed her access to an excellent college education which she greatly valued throughout her life. By casting her high achievement as typically Oregon and also practical, Brodie greatly enabled educational and science-based interventions in otherwise delicate areas of life: sex, sex education, and birth control.

Though she did not know about Margaret Sanger's controversial visit to Portland in 1916 until she was an adult, like Sanger, Brodie's experiences with families in poverty during medical school in the 1920's disheartened her and motivated her to seek ways for these women to efficiently and affordably access birth control information. Initially apprehensive of a comparison with Sanger, fearing a reputation of criminality, she 
eventually compared her experiences with those of Margaret Sanger in the 1910's, after determining that establishment of birth control clinics was not a violation of Oregon law. The most glaring commonality that Brodie highlights is the fact that she also saw women in extreme poverty die as a result of illegal or self-induced abortion and deliver up to sixteen children because of the lack of access to effective contraception. ${ }^{6}$ Sanger's historic association with radicals was celebrated in Portland culture, where by the 1960's they took great pride in Sanger's 1916 arrest and placed it as a contentious yet iconic event in Oregon's reproductive political history. At the time Brodie was invoking Sanger's name in the 1930s, the birth control leader had, according to historian Linda Gordon, distanced herself from some of her radical colleagues and reluctantly relinquished some of her control to "the professionals," doctors and eugenists, in order to bring credibility to the movement. ${ }^{7}$ In an effort to build upon the professionalism that now served as an example at the national level, Brodie, as a physician, chose to go through medical and legal channels rather than grassroots social organization in her attempt to establish a birth control clinic in Oregon.

In keeping with the somewhat conservative tone of reproductive policy making in the Great Depression, Brodie's most notable achievement, prior to working with Planned Parenthood Association of Oregon (PPAO) in the 1960's, was her involvement with the passage of an Oregon law, in 1935 that regulated birth control. This law, Chapter 126, Oregon Laws, 1935, set strict guidelines for manufacture and sale of contraceptives in the state, and limited access to licensed distributors of approved contraceptives. Though

\footnotetext{
${ }^{6}$ Brodie, Dr. Jessie, 4.

${ }^{7}$ Linda Gordon, The Moral Property of Women: A History of Birth Control Politics in America (Urbana and Chicago: University of Illinois Press, 2002), 177, 188.
} 
rarely remarked upon by legal scholars, Oregon's statute was the first law in the U.S. that directly overturned the Comstock Laws that had been in effect since 1873, prohibiting the manufacture, sale, and distribution of "obscene" or "lewd" material. ${ }^{8}$ Contraceptives and instruments used to induce abortion fell into this category of lascivious material at the federal level, but also in Oregon's own version of the Comstock Laws.

Consistent with progressive women physicians in other states, Brodie also used her role as a physician to appeal to the Multnomah Medical Society, in 1935 and 1936, in an effort to establish a birth control clinic for the medically indigent, which at the time was not a radical move, according to historian Ellen Singer More. ${ }^{9}$ Unlike the south, where white supremacist new deal administrators promoted contraceptive programs as a "valued service" and reserved access to "disproportionately" white areas, devaluing and limiting African-American women's access to birth control, Oregon stayed away from these early racist and classist innovations in birth control. The notion of exceptionalism in Oregon was invoked, by an investigative committee at the Multnomah County Medical Society with the explanation that a clinic of that nature was not needed in Oregon because it was a "non-restrictive" state and physicians were legally allowed to distribute contraceptive information to married patients. ${ }^{10}$ In other words, some of the classic legal and legislative battles typical of other states, or New Deal policies and experimentations that fostered reactionary birth control policy were missing in Oregon. On the affirmative

\footnotetext{
${ }^{8}$ Andrea Tone, Devices and Desires: A History of Contraceptives in America (New York: Hill and Wang, 2001), 22; Brodie, Dr. Jessie, 4.

${ }^{9}$ Ellen Singer More, Restoring the Balance: Women Physicians and the Profession of Medicine, 1850-1995 (Cambridge: Harvard University Press, 1999), 164-165.

${ }^{10}$ Letter from Frank Reid Mount, M.D, 10/4/35, p.3, JLB Papers, Box 6, “Contraception History” folder.
} 
side, as a result of the passage of Oregon's contraceptive legislation, Brodie's early career decision to help underprivileged women access birth control became a defining force and served as a launching point both for her lifelong goals and for Oregon's reproductive history.

The life experiences of "Dr. Jessie," as Brodie liked to be called, a moniker that softened the edge of her expertise and made her more accessible to her pediatric patients, fit almost perfectly into the historical record as an illustration of the sociopolitical transitions of birth control that occurred throughout the middle of the twentieth century. She was a birth controller in the 1930's, a marriage counselor and club woman in the 1940's and 1950's, and a family planning expert and medical matriarch and diplomat in the 1960'and 1970's. Brodie's actions and beliefs were so ingrained in the American culture and values that existed at certain points in her life that it seems she did not realize her immense contributions until later in her life, and was essentially unaware of her culturally and economically privileged biases. She saw herself as a resource and example to young women physicians and community activists and recognized the importance of this role in the writing of her autobiography, with the intention of illustrating that it was entirely possible to have a medical career in conjunction with a "well-rounded life with home, family, profession, and extensive community services."11

Though parts of Brodie's history fit into select facets of the general history of reproductive politics in the U.S., there are elements of her life and her actions that are unequivocally a product of practicing medicine and educational advocacy as a woman in Oregon, and by simply being an Oregonian. Brodie belonged to the Republican Party

\footnotetext{
${ }^{11}$ Brodie, Dr. Jessie, xiii.
} 
throughout her entire life, an affiliation not particularly noteworthy in her early birth control forays because Republicans were a driving force behind the movement during this period, but somewhat contentious later in her life in her involvement with Planned Parenthood, and after the Roe v. Wade decision in 1973, when the Democratic Party was increasingly becoming the driving force behind birth control. The Republican Party became more conservative as the century progressed, but Brodie's political values stayed relatively moderate, and could even be construed as liberal by the end of her life, especially in regard to birth control and abortion. She strongly felt that all women, regardless of class or race, should have access to contraception and the ability to control their reproductive capacity, evidenced by her statement that "fertility control is the right of every family" and that regardless of socioeconomic background these families should have the "freedom of choice of methods and no coercion." 12 In regard to abortion, Brodie believed it should be a legal option in dire situations, but made it extremely clear that she did not consider abortion a form of contraception. ${ }^{13}$

True to her "pioneer spirit" acquired in her childhood, Brodie maintained that in her experiences as a woman physician she "met a minimum of discrimination" and "developed a pride in the feminine attributes that made women particularly valuable in medicine."14 She contended throughout her life that she was not met with any "outright discrimination" toward her gender and did not have to fight for rights as a woman in Oregon. It is arguable that this was one of the reasons that she did not define herself as a

\footnotetext{
${ }^{12}$ Jessie Laird Brodie, "Where Oregon is Today in Family Planning," Northwest Medicine, Vol. 66, No. 11 (November 1967): 1037. Emphasis in original.

${ }^{13}$ Brodie, OHS Interview, 1978, 3.

${ }^{14}$ Brodie, Dr. Jessie, xii.
} 
feminist, even though many of her achievements and aspects of her activism could be interpreted as such. In a 1978 interview, she made it clear that her philosophy toward the birth control movement was educational in nature, not tied to feminism or suffrage. Always a proponent of traditional marriage values, Brodie also stated her displeasure with second wave feminist's demonstrations and "the way in which some of the women [had] weakened the marriage fidelity." 15 She felt that the link between the birth control and abortion debate and the women's movement of the 1970's would "cause more antagonism than anything else," but did agree with the feminist agenda in getting equal pay and rights for women, nationally, as she already felt she had these things in Oregon. ${ }^{16}$ Brodie had been an advocate for women seeking to balance a career, marriage, and motherhood since the 1930's when she was a young physician, wife, and mother. She clearly did not see these attributes of her life as feminist but historically, they fit into a maternalist feminist paradigm, and these features of her life defined her and influenced her opinions everywhere she traveled and practiced in the world.

Oregon's largest distinction from the rest of the country in regard to birth control, beyond that of the ideology of relative equality between the sexes, was the fact that they did not have to overcome as many legal barriers as other states because there were no laws that specifically prohibited contraception. Before the 1935 legislation, there were only two laws that existed in Oregon that could be interpreted as a having a tie to contraception. One prohibited acts that "openly outrage[d] the public decency and [were] injurious to public morals," and the other forbade production and distribution of materials

\footnotetext{
${ }^{15}$ Brodie, OHS Interview, 1978, 8.

${ }^{16}$ Ibid.
} 
that could be considered to be for "indecent or immoral use."17 Both laws were written very generally and did not place any restrictions on physicians or pharmacies, so it was never illegal to prescribe contraceptives in Oregon. This was a very different story compared to other places in the country where access to contraceptive information was illegal and sometimes posed legal ramifications if individuals possessed them, even when married. The 1965 Supreme Court decision, Griswold v. Connecticut, held that it was a violation of privacy to deny married couples access to contraception. This decision finally legalized birth control, though only for married couples, in Connecticut and Massachusetts the last two states where Comstock laws remained in effect. In 1972, the Supreme Court legalized birth control for all women, regardless of their marital status, with their decision in Eisenstadt v. Baird. Neither one of these decisions had a great impact in Oregon because they were already prescribing birth control to married and single women.

One reason, already alluded to, is the essentially conservative nature of Brodie's approach and her distinction from radical social movements or illegal activities like abortion. As Solinger has shown, Oregon had a thriving abortion business prior to the 1950's operating with little interference from law enforcement and with guarded respect from local physicians. Brodie herself recognized that local abortionists had a particular skill set to perform abortions safely and she respected their expertise with these procedures, which was not an entirely uncommon physician viewpoint in 1930's Portland society. Consistent with several other states abortion was legalized in Oregon in 1969 in cases that would "gravely impair mother's physical or mental health where child will be

\footnotetext{
${ }^{17}$ Letter from Zollinger, 11/1/33, p.2, JLB Papers, Box 6, “1933 Oregon Birth Control Legislation” folder.
} 
born with grave physical or mental defect or where pregnancy resulted from rape or incest," and if performed in a hospital setting. ${ }^{18}$ Upon passage of this bill, the Planned Parenthood Association started an abortion counseling service, to refer patients who wanted an abortion to the appropriate physician, but did not perform the procedures in their clinics until the 1990's.

In 1973, the Supreme Court legalized abortion nationally in Roe v. Wade, arguably the most important court decision relating to women's control of their sexual bodies, and provisions within the law actually nullified the 1969 Oregon law and existing laws in several other states, which were more conservative than the high court's construction of "zone of privacy." The decision gave women the freedom to obtain safe, legal, sanitary abortions any time in their first trimester without having to fear intervention of authorities, a provision not in the Oregon law, but welcomed by the liberal abortion proponents in the state. Betty Roberts, a state legislator and later Oregon's first state Supreme Court Justice, had attempted to include this provision in the 1969 Oregon law, but compromised with more conservative lawmakers by establishing strict guidelines for legal abortion. ${ }^{19}$

To support the argument of this thesis, that Oregon's unique situation of having relatively little legislation to strike down in regard to birth control made it easier to bring

\footnotetext{
${ }^{18}$ SB 193, Oregon Legislative Assembly, 1969 Regular Session (May 15, 1969).

${ }^{19}$ Betty Roberts with Gail Wells, With Grit and By Grace: Breaking Trails in Politics and Law, A Memoir (Corvallis: Oregon State University Press, 2008), 110-118; Ann Sullivan, "Court's Ruling on Abortion Will Have Local Impact,” Oregonian, January 23, 1973, accessed March 20, 2012, http://infoweb.newsbank.com.proxy.lib.pdx.edu/iwsearch/we/HistArchive/HistArchive?d_viewref $=$ doc\&p_docnum $=$ 1\&p_nbid=A48D49WEMTMzMzQ5MzzUMC43Nzg2NTQ6MToxMzoxMzEuMjUyLjk2LjI4\&f_docref= v2:11A73E5827618330@EANX-130EE6F69EEB6D97@2441706130D1ADD21B4DBCA@0\&toc=true\&p_docref=v2:11A73E5827618330@EANX130EE6F69EEB6D97@2441706-130D1ADF6B89003F@29.
} 
contraceptive services to the state, it was necessary to consult several secondary sources that address reproductive politics in the United States as a whole and internationally. For the national picture, three books were essential in to this thesis: Linda Gordon's, The Moral Property of Women: A History of Birth Control Politics in America, Rickie Solinger's, Pregnancy and Power: A Short History of Reproductive Politics in America, and Andrea Tone's Devices and Desires: A History of Contraceptives in America.

Linda Gordon's historical interpretation of birth control politics in America was extremely helpful for understanding Oregon's role in eugenic history in perspective to the birth control movement. Though she does not discuss Oregon in particular, her insight into the linkage between birth control and eugenics helped put Brodie's involvement with social hygiene and the marriage movement into perspective. Brodie's actions were in accordance to a larger national movement linking the two causes in order to professionalize birth control and further the eugenic cause even after its original popularity began to wane at mid-century. Gordon not only provides an explanation of how the two movements were linked, but also adeptly defines the deviation points between the movements. The main divisions she finds are the feminist origins of the majority of birth controllers and the rivalry and lack of cooperation between eugenists and physicians in regard to establishing clinics. Oregon had both eugenists and birth controllers, but it was social hygienists and physicians that fueled the birth control movement locally. Brodie fit the Oregon mold as a social hygienist and a physician, but also utilized aspects drawn from both birth controllers and eugenists, to push her birth control agenda in Oregon. 
Gordon's discussion of population control as a matter of U.S. domestic and foreign policy in the late 1950's and throughout the 1960's aided in understanding Brodie's role in international family planning during the 1960's and 1970's. She explains that by the 1960 's the American government "considered population control a necessary condition for economic development in the Third World," and by altering the domestic contraceptive history they promoted birth control as a means for these foreign countries to "bootstrap themselves upward both economically and socially." ${ }^{20}$ Brodie's career with the Pathfinder Fund from 1968-1975, epitomized the use of this vaguely social Darwinian rhetoric in an effort to establish family planning clinics in several Latin American and Caribbean countries, practices also indebted to missionary practices and institutions from the nineteenth century in various world locations.

Rickie Solinger's work was useful in understanding particular aspects of race in regard to reproductive politics in the U.S, especially in the 1950's and 1960's. She puts the population control rhetoric of this historical period into perspective, explaining the impact that it had on African-American communities nationally. Experts in the field blamed unmarried and cohabitating women for overpopulation problems, but singled out black women living in "the slums of the great Northern cities" as the major contributors to population issues, while concurrently praising and promoting married white middleclass women's fertility. ${ }^{21}$ Drawing on these social Darwinian and missionary ethos, Brodie's outreach to the Portland African-American community echoed with other national trends, in that while she was Executive Director of PPAO the organization

\footnotetext{
${ }^{20}$ Gordon, Moral Property of Women, 283.

${ }^{21}$ Rickie Solinger, Pregnancy and Power: A Short History of Reproductive Politics in America (New York and London: New York University Press, 2005), 165.
} 
established a birth control clinic in a predominantly African-American neighborhood of Portland. PPAO was able to open this clinic with the help of the War on Poverty's federal funding, fitting directly into the national mold of limiting African-American women's fertility. This thesis argues that though the placement of this clinic was strategic, the leaders did not indicate that it was specifically to limit the AfricanAmerican population, in fact they are very specific in stating that they believed that access to birth control should be a choice for every woman free from coercion. A related set of concerns characterized Brodie's consultancy around issues of migrant workers health, prenatal, and family planning issues in rural Oregon, a side of the story not well treated in the standard accounts of birth control as a distinctly national issue, but more of a regional concern, especially in regard to Latin American migrant workers. ${ }^{22}$

Andrea Tone's detailed history of contraceptives in America helped not only to understand the development and use of the birth control pill and the IUD domestically, but explained their impact and use internationally. Tone asserts that the pill "created widespread doctor and patient acceptance of medical birth control" and led to the development and use of IUD's, Norplant, and Depo-Provera. ${ }^{23}$ She discusses the pill in relation to the "population crisis" outside of the U.S. and explains that the original intention behind it was "to supply critical ammunition in the war against unwanted population growth in developing countries. ${ }^{24}$ Birth control trials were conducted by Gregory Pincus throughout the 1950's in both Puerto Rico and Haiti, all the while

\footnotetext{
${ }^{22}$ Solinger, Pregnancy and Power, 110-114.

${ }^{23}$ Andrea Tone, Devices and Desires: A History of Contraceptives in America (New York: Hill and Wang, 2001), 203.

${ }^{24}$ Ibid., 207.
} 
receiving letters from American women offering to be test subjects. ${ }^{25}$ Tone stated that women in the U.S. "were quick to accept oral contraceptives" and within two years of FDA approval in 1960, "1.2 million women were taking the Pill, within five years, over six million." 26 Brodie believed that the pill had a significant impact on international birth control, evidenced to her in her Pathfinder duties, because of the low expense and the ability of women to use the pill without the direct medical supervision that was necessary for the use of IUD's or diaphragms. ${ }^{27}$

In looking at the international picture, all three authors provided insight to American birth control advocates forays into foreign countries, but Laura Briggs' Reproducing Empire: Race, Sex. Science, and U.S. Imperialism in Puerto Rico, offered a clear picture of how sexuality and reproduction contributed to U.S. colonial control, specifically in Puerto Rico, though the same arguments could be made for other U.S. dealings in Latin America and the Caribbean as well. Briggs' detailed explanation of the link between colonialism and reproductive control in Puerto Rico sheds increased light on the fact that researchers developed the pill "as a specific technological fix to the Third World problem of population" and criticized the use of Puerto Rican mother's as sexually deviant laboratory subjects. ${ }^{28}$ She also critiques the eugenic nature of the selection of Puerto Rico as a site for birth control trials and the ideals of many of the researchers that overpopulation and poverty were directly linked to the deviant sexuality of Puerto Rican mothers. This history is important in Brodie's Latin American family planning work

\footnotetext{
${ }^{25}$ Ibid., 226, 234.

${ }^{26}$ Ibid., 233.

${ }^{27}$ Brodie, OHS Interview, 1978, 20.

${ }^{28}$ Laura Briggs, Reproducing Empire: Race, Sex. Science, and U.S. Imperialism in Puerto Rico (Berkeley and Los Angeles: University of California Press, 2002), 141.
} 
because Pathfinder targeted other countries in the region, most notably Haiti and Guatemala, as ideal locations for the establishment of birth control because of the high levels of poverty and reproduction. Jessie Brodie was influenced by the widely published professional discourses about population control and indeed, contributed to them as well through numerous scholarly articles published in The Journal of the American Medical

\section{Women's Association.}

I found these particular articles in the Brodie papers outside of Oregon and referenced to in her autobiography. Brodie's personal papers are held in the Legacy Center at Drexel University College of Medicine, formerly Woman's Medical College of Pennsylvania. As a prior president of the American Medical Women's Association, and with that particular organization's direct link to the medical school, Brodie wanted her papers housed in an archive that contained a vast holding of prominent American women physicians, as she felt her story was as pioneering and remarkable as her predecessors and contemporaries. Brodie kept excellent records and used her own papers to aid her in writing her autobiography, also integral to this thesis, which allowed me to both verify and refute her recollections. She left an incredibly rich, organized history of her life in her personal documents that included not only personal and professional correspondence, but also invaluable newspaper and journal articles that helped me interpret her contributions to Oregon's reproductive political history in a more comprehensive manner than I would have been able to without them. Planned Parenthood's meeting minutes, from their inception through 1975, put their history in perspective with Brodie's, 
illustrating a richer, more complete history of reproductive politics in Oregon than I had originally anticipated.

Briefly, the three chapters of this thesis focus on Jessie Laird Brodie and her direct impact on the history of reproductive politics in Oregon. Chapter one looks at Brodie's early career as a woman physician in Oregon and her involvement with 1930's contraceptive and marriage legislation. Chapter two focuses on Brodie's continued local involvement and how she took Oregon's vision for women to the national and international level. Finally, the third chapter emphasizes Brodie's role in the success of PPAO in the 1960's and her career with the Pathfinder Fund where she was able to bring family planning to several Latin American and Caribbean countries. Brodie's life is integral to the history of reproductive politics in Oregon and the fact that the state had few legal limitations to overcome in that history makes this story unique to the national and transnational birth control histories written up to this point. 


\section{CHAPTER 1}

“We Were Privileged in Oregon...": A Pragmatic Approach to Reproductive Politics

In June of 1916, in North Portland, a young woman named Jessie Laird graduated from Jefferson High School and enjoyed the summer before college with her group of friends, who called themselves Laufalot. ${ }^{1}$ That same month Margaret Sanger spent the night in a Portland, Oregon jail, answering to charges of obscenity, for distribution of her birth control pamphlet, Family Limitation. As this lighthearted moniker suggests, this group of young women was oblivious to the happenings with Sanger that June. Later in her life, Laird attested, to a group of Clark College students, that she was either "too young, or too busy, to attach any significance to the news item." ${ }^{2}$ Nonetheless, as Jessie Laird developed her adult sociopolitical consciousness, she looked back on these historic events to guide her in decision-making processes concerning the legality of birth control in Oregon. Though the issue relating to these events was political in nature, Laird viewed reproductive control through scientific, medical, and educational lenses and acted strategically across medical, political, and social lines to build upon the base provided by Sanger, Marie Equi, and others to pave the way for birth control in the State of Oregon.

Laird played a crucial role in shaping reproductive politics in Oregon in the middle decades of the twentieth century. Drawing less on intellectual radicalism and alliances with the working class favored by figures like Sanger and Equi, Laird was

\footnotetext{
${ }^{1}$ Brodie began her association with the group, originally Laugh-a-lot, during the summer of 1915 . They maintained a friendship for over 70 years.

${ }^{2}$ Economic, Social, and Moral Aspects of Birth Control, May 24, 1967, p.1, Jessie Laird Brodie Papers, Box 7, "Birth Control Articles" folder, Legacy Center, Drexel University College of Medicine (hereafter JLB Papers).
} 
instead drawn to social and political change through education, professionalization, and community activism. Laird believed that change would not happen by writing and speaking about it, but by taking strategic steps at the local level, repeatedly and with community support, to make that change occur. Her service-minded nature materialized during her time at Reed College where her education emphasized community service in addition to a comprehensive, rigorous, yet balanced, intellectual liberal arts curriculum. Brodie took her education and continued to build on the foundation that she laid at Reed throughout the rest of her life and career.

Jessie Laird started at Reed in the fall of 1916 where she took classes to prepare her for teaching as well as medical school. Laird wanted to be a physician, but her father, having gone to medical school in the late 1800's, urged her not to because of the abhorrent way women were treated. ${ }^{3}$ He did not like the fact that women, or "hen medics" as they were derisively called while he was in medical school, were seen as either abortionists or "untrustworthy," and because he "feared that this harassment was still continuing," he did not want his daughter to have to endure the same. ${ }^{4}$ Respectful of her father's wishes, though still resolved to pursue a career in medicine eventually, they came to the compromise that she would take classes that could be used for either degree.

Laird graduated with a bachelor's degree in biology in 1920 and the following fall took a job teaching experimental biology to elementary school children in Newberg,

\footnotetext{
3 Jessie Laird Brodie, M.D., "Dr. Jessie”: The Odyssey of a Woman Physician (Portland: Carolina Pacific Publishing, 1991), 19. While he was in medical school often the male medical students would sneak parts from the dissected cadavers into the beds of the female medical students.

${ }^{4}$ Original Manuscript, Author's Note, p2. JLB Papers, Box 8, “Articles and Speeches, by J.L. Brodie, M.D.” folder.
} 
Oregon. $^{5}$ This experimental program was part of a grant obtained by the Oregon Social Hygiene Association, in conjunction with the National Board of Education, and focused on teaching young children the proper terminology and function of mammalian reproductive parts so that when they were older they had a better understanding of the reproductive cycle. ${ }^{6}$ The thought behind this program was that if children learned the "proper nomenclature for various organs of the body," and the "facts of nature and life processes, including reproduction," that there would be a decrease in the "emotional stress" of adolescence. ${ }^{7}$ The success of this pilot program solidified Laird's belief in the value of explicit and direct sex education, and the assumption that through this education women, especially, could gain a sense of reproductive control in their lives.

After two years of teaching Newberg students experimental biology, with very little opposition due to the fact that the program was explained with the premise that it taught science "as to scientific method of thinking and not to cover up any facts," Laird was asked to introduce the program to Portland Schools. ${ }^{8}$ She was unable to fulfill this request as she had married F. Walter Brodie in June of 1921, and married teachers were not permitted to teach in the Portland School District, a rule which Laird later thought was "a matter of feeling that the unmarried teacher had no husband to supply the funds that were necessary." According to Jessie Laird Brodie, there were some married

\footnotetext{
${ }^{5}$ Brodie, Dr. Jessie, 31.

${ }^{6}$ Curriculum Vitae, with special attention to Planned Parenthood experience, prepared July 1965. JLB Papers, Box 7, “Articles and Speeches, by J.L. Brodie, M.D.” folder.

${ }^{7}$ Dr. Jessie Laird Brodie, interview by Roberta Watts, Oregon Historical Society, February 14 and March 29, 1978, 6; Brodie, 1991, 31, 33.

${ }^{8}$ Brodie, OHS Interview, 1978, 5.

${ }^{9}$ Ibid.; Brodie, Dr. Jessie, 38.
} 
teachers who tried to cover up their marriages in order to keep their positions, but if they were discovered "they were fined and had to pay all their back salaries."10

Rather than deceiving the school district and putting this hiring rule to the test, Brodie opted to continue her involvement with the Oregon Social Hygiene Association and took a job as a research assistant in experimental biology at the University of Oregon Medical School where she worked on various research projects. This extra income helped the Brodie's while Walter was finishing medical school. Brodie was permitted to take classes in "histology, biochemistry, and pathology with the regular medical students," to aid her in her new position and two years later, in 1925, she was able to obtain her Master of Arts degree in experimental biology and pathology. ${ }^{11}$ Brodie's original plan of attending medical school finally came to fruition when she was approached by the Assistant Dean of the program and asked to enter as a second year med student in 1926. By this time her father had come to the conclusion that women were not treated as badly as they had been while he was in medical school and became Brodie's "greatest supporter" offering encouragement and aiding her when needed throughout the rest of her education. ${ }^{12}$

According to her own account, medical school provided Brodie with countless experiences that fostered her interest in birth control, especially in regard to the relationship between poverty and family size, and the limitations this demographic had to accessing contraception. She was one of two women to graduate with the University of

\footnotetext{
${ }^{10} \mathrm{Ibid}$.

${ }^{11}$ Brodie, Dr. Jessie, 41.

${ }^{12}$ Ibid., 42. When Brodie's father was ill several years later he considered his daughter the only person "capable of giving him hypodermic injections."
} 
Oregon Medical School class of 1928. A statement made by one of the forty-eight men in one of her senior classes prompted the entire class to request that their instructor give his final lecture on birth control. Up to this point the seniors had not received any education on birth control and several of them wanted information so that they would not have large families, and so they could counsel their patients about contraception. At this time in history it was not common to include contraception in medical training as it was not yet accepted by the American Medical Association (AMA) and was still subject to Comstock laws from the 1800 's, that limited the circulation of so-called obscene literature, that had not yet been repealed. In 1944, Dr. Alan Guttmacher, then an obstetrics professor at Johns Hopkins University and later President of Planned Parenthood Federation of America (PPFA), discovered in a survey of 3,381 doctors, "that only 10 percent of graduates before 1920 had received training on contraception, but fully 73 percent of those who had graduated in 1935 or later had." ${ }^{13}$ Because contraception curriculum was not common to include in medical school, Brodie's professor responded to the class request with a look of "consternation," "If you would look at doctors' families, you would know that we don’t know a damn thing about it!" ${ }^{14}$ This statement rang in Brodie's ear throughout her entire career prompting her to find ways to offer these services to families who needed contraception as an option.

\footnotetext{
${ }^{13}$ Andrea Tone, Devices and Desires: A History of Contraceptives in America (New York: Hill and Wang, 2001), 135. While Brodie was in medical school, contraception was gaining ground in the medical community and by the mid-1930's it was common for medical students to receive contraceptive training. According to Tone, instructional time devoted to contraception, especially concerning the "effectiveness of the diaphragm-and-jelly method," rapidly increased "in the interwar years as medical support of birth control grew." As Brodie was entering medical school in the mid-1920's the "American Gynecological Society and the Section on Obstetrics, Gynecology, and Abdominal Surgery of the AMA had endorsed therapeutic birth control," though the Comstock laws would not be officially repealed until 1936, and the AMA as a whole, would not endorse birth control until 1937.

${ }^{14}$ Brodie, Dr. Jessie, 1-2.
} 
At a time when women had a difficult time securing internships after medical school, Brodie was able to procure a spot as an intern at Multnomah County Hospital in Portland, "which was then the only teaching hospital in the Northwest."15 During her internship, Brodie saw other situations that led to her eventual specialty of pediatrics and adolescent gynecology and to her intense interest in birth control. At the county hospital it was not uncommon to see patients who had infections or lost their lives because of selfinduced or illegal abortions. Often, Brodie came across women patients who needed to avoid pregnancy for medical reasons, but were unable to because of their lack of access to contraception, most frequently due to poverty. Their inability to access birth control led to unwanted or dangerous pregnancies that were frequently terminated through selfinduced or illegal abortions, sometimes ending in fatality. If a patient did not suffer fatally from these abortions, "another pregnancy was unthinkable," according to Brodie, but still the fact remained that these patients had no access to contraceptive resources. ${ }^{16}$ Brodie recalled her frustration "over my helplessness to prevent this needless loss of life!"17 Where Brodie was able to control her own fertility, and as a result, her reproductive health, she became increasingly exasperated that she could not help many of these poverty-stricken women simply because they could not pay for birth control. Brodie's desire to reach out to indigent populations was not unique for women physicians during the 1920's and 1930's. In fact, she could be grouped with other women doctors around the country who, despite overall disapproval from the medical profession, "did

\footnotetext{
${ }^{15}$ Ibid., 49.

${ }^{16}$ Ibid., 55.

${ }^{17}$ Ibid., 2.
} 
take a strong public stand in support of birth control, especially in making it available to the poor," under the pretense of preventing high rates of maternal and infant mortality. ${ }^{18}$

On one occasion Brodie went to a woman's home who complained of heavy vaginal bleeding. When she arrived the patient said she was feeling better and did not need help from Dr. Brodie any longer. After further inquiry, the woman told Brodie that Dr. Ed Stewart, a local abortionist, was waiting for her to leave so that he could help the patient with the situation. Brodie remembered that she "withdrew immediately, leaving the field to Dr. Stewart, one of the city's well-known abortionists." ${ }^{19}$ As a physician in Portland during this historical period it was well known, but rarely spoken about in Brodie's social circle, that there were several abortionists who had thriving practices. ${ }^{20}$ Brodie did not stand as a strong proponent of abortion, believing that education and contraception were far better alternatives, but recognized that it was a reality and that the abortionist's skills outweighed hers in this particular instance. The police tended to turn a blind eye, as did many doctors, because officers often solicited abortionist's services for illicit affairs, and the clinicians were extremely adept at their occupation whereas regular family physicians lacked adequate experience to safely perform abortions.

Unfortunately, for the majority of women who found themselves with an unwanted pregnancy, the skilled abortionists' services were far too expensive. Because these women could not afford a safe abortion, performed by a skilled abortionist, they tried to

\footnotetext{
${ }^{18}$ Ellen S. More, Restoring the Balance: Women Physicians and the Profession of Medicine, 1850-1995 (Cambridge: Harvard University Press, 1999), 164-165.

${ }^{19}$ Brodie, Dr. Jessie, 3.

${ }^{20}$ Abortionist Ruth Barnett discusses the different providers and practices in her autobiography, They Weep on My Doorstep (Beaverton, OR: Halo Publishers, 1969). There were at least three skilled abortionists practicing in Portland during this time. Barnett took over Dr. Stewart's practice when he retired in 1945. She had already procured Dr. Maude Van Alstyne and Dr. George Watts' clinic in the 1930s, so when Barnett acquired Stewart's clinic she had a monopoly on the abortion market.
} 
induce abortion with coat hangers or knitting needles and ended up in the county hospital, most often with perforated uterine walls. ${ }^{21}$ Brodie iterated that it was difficult to treat these patients, and that they "lost many of these patients, since antibiotics had not yet been discovered.",22

During her time in medical school and early on in her private medical practice, Brodie also came across families who were having up to sixteen children. Many of these families could not afford it, having to divide very little food, sometimes among as many as eighteen people. She noted the "mother's desperation when [they] learned that there was another child on the way" and said that during this depression era she was "called, not uncommonly, to treat hemorrhage or infection caused by self-induced or illegal

\footnotetext{
${ }^{21}$ Brodie, Dr. Jessie, 55. According to both Rickie Solinger and Leslie Reagan, Brodie's experiences with illegal abortions in the county hospital were not unlike other areas of the country. Those women who could not afford to obtain a "quick, clean" abortion would attempt to terminate their pregnancies on their own. Reagan says that, not unlike Brodie, "the suffering that so many doctors witnessed made many willing to help women seeking abortions." Leslie Reagan, When Abortion Was a Crime: Women, Medicine, and Law in the United States, 1867-1973 (Berkeley: University of California Press, 1997), 146. Reagan also reports that there were four clear stances that physicians had toward abortion during the early 1900's: those who adamantly refused to help women and were against abortion entirely, those who did not do abortions themselves but would refer their patients to those who would provide a safe abortion (the most common stance in this illegal era), those who would occasionally provide therapeutic abortions for their own patients, and those who performed abortions on a regular basis, or so-called "professional" abortionists. (Reagan, 54) These "specialists," as abortionists began to be referred to as in the 1930's, were "unofficially" recognized for their skills by the medical profession in that these physicians referred their patients to "physician-abortionists." (Reagan, 148) This way, doctors could send their patient to skilled, "highly regarded" colleagues, avoiding high risk situations for the women obtaining abortions, and to keep their personal practices out of trouble with the law.

Solinger explains that Brodie is correct in her statement that, for many women, an abortion from a skilled professional was out of the question mainly because of cost. She explains that "people who performed abortions made good money, and many turned over hefty wads of cash each month to law enforcement as insurance against arrest." Rickie Solinger, Pregnancy and Power: A Short History of Reproductive Politics in America (New York: New York University Press, 2005), 118. Reagan estimated that the average cost of an abortion was sixty-seven dollars, but often a sliding scale was put in place allowing lower-income patients to pay less and for wealthier patients to pay more for specialist abortion services. Solinger states that "a skillful practitioner... was unlikely to damage an abortion patient or cause her death." (Solinger, 118) Because of the abortionists expertise and relative safety they provided for women seeking an abortion, both physicians and law enforcement tended to accept and protect abortionists in their community.

${ }^{22}$ Brodie, Dr. Jessie, 55.
} 
abortions." ${ }^{23}$ Brodie "thought often of the need to adjust the number of children to the size of income." 24 After witnessing familial situations such as these, Brodie became interested in helping these types of families control their reproduction, but she had had no instruction as to how to accomplish this in medical school. The clientele in the Brodie's shared office consisted mostly of young families as Brodie was a pediatrician and her husband was an obstetrician. At the urging of her male pediatric colleagues in Portland, Brodie decided to extend her area of practice to include adolescent gynecology because most male pediatricians dropped female patients "like 'hot potatoes' when they reached twelve years of age." 25 At that point of development, male physicians determined that girls needed a woman physician to aid them through the multiple physical and emotional changes that occur during adolescence. With the addition of adolescent gynecology and family planning to her practice it was unsurprising that Brodie became increasingly interested in providing birth control. ${ }^{26}$ When the opportunity to visit clinics established

\footnotetext{
23 "Birth Control: How it Came to Oregon," Northwest, July 10, 1968. JLB Papers, Box 7, "Birth Control Articles" folder.

${ }^{24}$ Brodie, Dr. Jessie, 2. Brodie never specifically speaks about services that the county hospital provided for unwed mothers or about unwed mothers homes, but they were definitely in existence in Portland at this particular point. The White Shield Home, a division of the Salvation Army, was established in Portland in 1917 specifically to provide services for unwed mothers. It was not however, the first home of its kind in the area. A division of the Florence Crittenton homes had been established here in 1897, the Pacific Coast Rescue and Protective Society, later the Albertina Kerr Center, was established in 1907, and in 1908 the Louise Home for Girls was established in conjunction with Albertina Kerr. Catholic Services for Children also provided various services for unwed mothers and adoption services. There was not an influx of establishment of these unwed mothers homes during Brodie's time in medical school or early years of medical practice, but these services did rise again in the 1950's and 1960's.

${ }^{25}$ Ibid., 111.

${ }^{26}$ Ibid., 112.
} 
by Sanger in New York came up, Brodie went and quickly began implementing what methods she could in her private clinic. ${ }^{27}$

Out of Brodie's interest in finding effective ways to provide contraceptives to those who, she claimed, desperately needed it, came one of her most significant contributions to Oregon's birth control history. In the early 1930's, Brodie was approached by, and according to her, "easily persuaded when," the League of Women Voters, the local chapter of the American Association of University Women (AAUW), the Oregon Social Hygiene Society, and the local PTA, asked her to investigate the possibility of establishing a birth control clinic in Portland. ${ }^{28}$ Though extremely attracted to the idea of being involved in establishing a contraceptive clinic in Portland, Brodie did have some legal reservations stemming from Sanger's arrest in Portland in 1916. Brodie was worried that if those particular laws were still in effect and she were to disseminate contraceptive information, she might be subject to arrest and incarceration and stated that "this was not the way [she] wished to start [her] career as a doctor." ${ }^{29}$ Her fears about the possibility of prosecution under federal laws were justified as doctor's in other states

\footnotetext{
27 "Economic, Moral, and Social Aspects of Birth Control," prepared for a speech at Clark County College in Vancouver, WA, May 24, 1969, JLB Papers, Box 7, "Birth Control Articles" folder; Brodie, "Birth Control," JLB Papers, Box 7, "Birth Control Articles" folder.

${ }^{28}$ Brodie, OHS Interview, 1978, 7; Brodie, "Birth Control," JLB Papers, Box 7, "Birth Control Articles" folder; Brodie, Dr. Jessie, 3. When interviewed later in her life Brodie denied that her trying to open a birth control clinic at the request of the AAUW and the LOWV was a part of the women's movement. She criticized both of the organizations that approached her with this idea for not following through with the birth control movement. Brodie particularly ridiculed the LOWV saying that the local chapter did not include their involvement with birth control in their history until the mid-1970's when Brodie gave them information in an interview. She said they "took my statements as to what developed from it so they have a feeling of pride that they had a hand in it. It didn't develop within the League or, I think, AAUW. But it was not opposed either." From her statements it can be deduced that these groups were interested in supporting birth control when they approached her to begin with, but after the contraceptive legislation passed in Oregon their interest and involvement dwindled.

${ }^{29}$ Brodie, Dr. Jessie, 3.
} 
were still being arrested for distribution of contraceptive information and advice, but Brodie needed to determine what her restrictions were, specific to Oregon law.

Clifford E. Zollinger, a lawyer and friend of Brodie's, investigated the legality of opening such a clinic in Oregon. Zollinger found that indeed it was illegal to distribute contraceptive information through the mail because of federal Comstock laws. ${ }^{30}$ Oregon was obliged to follow these federal laws, as was the rest of the country. There were not, however, any Oregon statutes that specifically banned contraceptives and abortion. Zollinger only found two sections from the 1930 Oregon laws that could be construed as closely relating to birth control.

The first, Section 14-722, Oregon Code 1930, said that if a person committed an act that outraged public decency and was "injurious to public morals," they would be punished with one to six months in jail or fined. ${ }^{31}$ The second code, 14-729, said that it was illegal to import, design, publish, or sell "any article or instrument of indecent or immoral use." ${ }^{32}$ Both of these sections had cases establishing precedent for their use by the time Zollinger was investigating. Code 14-722 went to the Oregon Supreme Court in the case of State v. Atwood, 54 Ore. 526, where Atwood was charged with opening a maternity hospital specifically for "willfully, wrongfully and unlawfully committing, producing and procuring abortions." 33 The Court held that this was a direct violation of code 14-722, as it was injurious to public morals and was an "indirect crime against

\footnotetext{
${ }^{30}$ Letter from Clifford Zollinger, 11/1/1933, JLB Papers, Box 6, "1933 Oregon Birth Control Legislation" folder.

${ }^{31}$ Ibid., 2.

${ }^{32}$ Ibid., 2.

${ }^{33}$ Ibid., 2.
} 
society," and that unnecessary abortions were "malum in se," or inherently immoral. ${ }^{34}$ Code 14-729 was violated in State v. Andrews, 55 Ore. 388, where the Court ruled that exhibition of obscene photography was illegal as it was indecent. ${ }^{35}$

Zollinger came to the conclusion that there was nothing specifically prohibiting the distribution of contraceptive information or the use of contraceptives as long as it did not interfere with public decency and public morals, which would be in violation of code 14-729. If Brodie could find a way to distribute contraceptive information without directly violating either one of these Oregon laws, or the federal laws pertaining to mailing of such "obscene" materials, Zollinger could find no reason why it would be illegal to open a contraceptive clinic. As it stood at the time he believed "that fear of conception [had] tended to prevent promiscuous intercourse," but a clinic of this sort could unintentionally cause this fear to dissipate and an increase in licentious sexual behavior. ${ }^{36}$ Zollinger cautioned that if a clinic of this sort were to be established it would be advisable to make sure that contraceptives would not end up in the hands of those who would use it to engage in "illicit intercourse." ${ }^{37}$ If birth control did end up in the "wrong hands" public morals could be "adversely affected," which would be unlawful.

Brodie outlined the information that she found through Zollinger and sent a proposal for the establishment of a birth control clinic to the Council of the Multnomah County Medical Society in early 1935. Her intentions were specifically of a professional nature and stemmed from the fact that as a pediatrician and a mother herself, she "saw the

\footnotetext{
${ }^{34}$ Ibid., 3. Code 14-722 was also violated in cases of gambling, horse racing, and illicit intercourse.

${ }^{35}$ Ibid., 4.

${ }^{36}$ Ibid., 4-5.

${ }^{37}$ Ibid., 5 .
} 
problems that mothers were up against" and wanted to attack the issue of birth control from an "educational standpoint." control at the federal level, and was still two years away from doing so, Sanger and the American Birth Control League (ABCL) were gaining significant ground as birth control clinics were being established around the country through state and federal maternal and child health departments, in addition to clinics set up through medical schools, hospitals, and eugenic societies. ${ }^{39}$ These clinics were not only for indigent patients but also for "any married woman without question as to financial status. $" 40$ As Brodie explained in her report to the Medical Society, many of the clinics ran strictly on a donation and volunteer basis, with both physicians and nurses distributing the contraceptive information to patients. A June 1935 report from the ABCL indicated that there were two hundred and three "Centers for Contraceptive Advice in the United States," all with different requirements to receive services at their locations. ${ }^{41}$ In her prospectus, Brodie cites two hundred twenty-five clinics in the United States, which meant that this was the "highest ratio of clinics to population of any nation in the world," second only to Russia. ${ }^{42}$ The two "centers" listed for Oregon were the University of Oregon (U of O) Medical School outpatient clinic and the Oregon Social Hygiene Society clinic. ${ }^{43}$ The only restriction the $\mathrm{U}$ of $\mathrm{O}$ clinic had was that patients be in a "state of marriage and good reasons for limiting the number of children in the family." ${ }^{44}$ The Social Hygiene Society

\footnotetext{
${ }^{38}$ Brodie, OHS Interview, 1978, 7.

${ }^{39}$ Centers for Contraceptive Advice in the U.S., JLB Papers, Box 6, "Contraception History" folder.

40 "My Fight for Birth Control," p.4, JLB Papers, Box 6, "Oregon Contraception Law" folder.

${ }^{41}$ Centers for Contraceptive Advice in the U.S., JLB Papers, Box 6, "Contraception History" folder.

42 "My Fight for Birth Control," p.4, JLB Papers, Box 6, "Oregon Contraception Law" folder.

${ }^{43}$ Centers for Contraceptive Advice in the U.S., p.10, JLB Papers, Box 6, "Contraception History" folder.

${ }^{44}$ Ibid.
} 
was "free to all." 45 Even with these resources, Brodie sought to establish a clinic that was specifically for contraceptive advice and education in addition to marriage and family counseling.

The Multnomah County Medical Society’s committee on Public Health and Hygiene investigated the need for a clinic of this sort through a "casual survey" coming to the conclusion, in October of 1935, that there was "no special need" for a birth control clinic at that particular point. ${ }^{46}$ Their justification came from the fact that, as there was no law in Oregon specifically prohibiting distribution of contraceptives by physicians, many doctors were already doing so for married patients who inquired about birth control methods. This committee found no reason why contraceptive information should not continue to be provided to married women who sought it out, but specifically stated that it would be unwise to distribute "contraceptive information or materials to unmarried persons or to prostitutes." 47 In their opinion, dissemination of birth control information to these particular groups of women would violate Oregon's law that prohibited distribution of obscene material, due to their marital status and/or their lewd profession. Furthermore, they informed Brodie that patients who wanted contraceptive information but were not able to pay could continue going to the University of Oregon Medical School clinic. If a patient did not meet these requirements they could be seen at the Oregon Social Hygiene Society clinic free of charge and with no restrictions. ${ }^{48}$ Either clinic, or the Medical Society itself, would provide a list of private physicians who were

\footnotetext{
${ }^{45}$ Ibid.

${ }^{46}$ Letter from Frank Reid Mount, M.D., 10/4/1935, JLB Papers, Box 6, “Contraception History” folder.

${ }^{47}$ Ibid.

${ }^{48}$ Centers for Contraceptive Advice in the U.S., p.10, JLB Papers, Box 6, "Contraception History" folder.
} 
willing to treat patients seeking contraceptive advice and those who would adjust fees to "meet the patient's circumstances." 49

Six months after the Medical Society denied the need for a birth control clinic, in April of 1936, letters were sent to three social workers in the Portland area from Marguerite Benson, Executive Director of the ABCL, inquiring about the lack of birth control resources in Oregon. Benson critically observed that there was no specific clinic in Oregon so inquiries were sent to social agencies and forwarded to physicians, a system which was not necessarily desirable or affordable for many women. She asked how these women social workers proposed to provide birth control services to the poor Oregonians who could not afford to pay physicians for contraceptive advice or devices, and then offered the "full facilities of the League" in order to help establish a clinic. ${ }^{50}$ Celestia Coulson, one of the social workers, forwarded the letters to Brodie, who had recently been appointed Chairman of the National Committee on Federal Legislation for Birth Control (NCFLBC) in Portland by Gladys DeLancey Smith, California and West Coast Representative for the NCFLBC. ${ }^{51}$

In her letter, Benson also asked about what she claimed to be the first birth control organization in the country, started in 1914 in Oregon, and what became of these services in Portland. ${ }^{52}$ Brodie knew nothing about this so-called organization and informed Benson of this, in addition to providing her with the report of the current status of

\footnotetext{
${ }^{49}$ Letter from Frank Reid Mount, M.D., 10/4/1935, JLB Papers, Box 6, "Contraception History” folder. ${ }^{50}$ Letter from M. Benson to Celestia Coulson, 4/14/36, JLB Papers, Box 6, "Oregon Contraception Law" folder.

${ }^{51}$ Letter to Marguerite Benson from JLB, 5/2/36, JLB Papers, Box 6, "Oregon Contraception Law" folder. ${ }^{52}$ Letter from M. Benson to Celestia Coulson, 4/14/36, JLB Papers, Box 6, "Oregon Contraception Law" folder.
} 
contraception in Oregon and the services they were able to provide for disadvantaged women seeking help. Benson was indeed correct about a Birth Control League being established in Portland, though it was not until April of 1915. The league was formed by 100 people in Portland in a gathering at the Central Library where they stated that their intention was to study "Neo-Malthusian ideas and place them before the public." ${ }^{53}$ They sought to change public opinion so that "laws making it a crime to impart information regarding the physiologically harmless control of human offspring by artificial methods of preventing conception" could be repealed. ${ }^{54}$ It is unclear when this organization disbanded, or if they dissolved at all, but by the time Brodie received this letter it is clear that her generation of League members was unaware of the original local association with the national birth control movement.

Though Brodie could not obtain the approval for a birth control clinic from Multnomah County, despite demand coming from both local and national levels, she and Zollinger were successful in their attempt to accomplish something significant in the realm of birth control and contraception in Oregon. In 1934, they introduced a law to the Oregon legislature that would "attempt to remedy the uncontrolled sale of inferior contraceptive materials" and, secondarily, to get a feel of what the public interpreted as "obscene" in the hopes of eventually being able to create birth control clinics in

\footnotetext{
53 "Birth Control Defended," Morning Oregonian, April 30, 1915, http://infoweb.newsbank.com.proxy.lib.pdx.edu/iwsearch/we/HistArchive/?p_product=EANX\&p_theme=ahnp\&p_nbid=F5EA50OOMTMyNjY3MjA1MS41 MzQ1ODM6MToxMzoxMzEuMjUyLjk2LjI4\&p_action=doc\&s_lastnonissuequeryname $=4 \& d$ _viewref $=$ se arch\&p_queryname $=4 \& p \_$docnum $=4 \& p \_$docref $=$v2:11A73E5827618330@EANX11EDEDF1A51DD0D8@2420618-11EDEDF2060B4D60@1011EDEDF38A0D74B0@Birth+Control+Defended 54 "Birth Control Defended," 1915.
} 
Oregon. ${ }^{55}$ Before this law was introduced it was not uncommon to find "contraceptives of questionable quality," mostly condoms, sold in gas station vending machines, marketed in drugstore windows, or advertised in newspapers. ${ }^{56}$ Usually "of questionable quality" meant that the products were cheaply produced, had unreliable results, or both. The law was met with little opposition and went into effect as Chapter 126, Oregon Laws, 1935, establishing the first positive legislation on birth control in the United States. ${ }^{57}$ National reaction in the birth control community appeared in Sanger's The Birth Control Review shortly after the passage of this legislation, touting the provisions of the innovative law that set quality standards and limited distribution to state licensed pharmacies and physicians. In addition, the journal recognized the potential of this "valuable bill" to serve as a gateway to the possibility of similar legislation elsewhere in the country. ${ }^{58}$

The law established a division of the Oregon State Board of Pharmacy that was specifically dedicated to licensing retailers and implementing strict manufacturing guidelines for contraceptives. Two types of licenses could be obtained under the law, either wholesale or retail. Wholesale licenses were available to wholesale druggists who

\footnotetext{
55 "The History and Present Status of Contraception in Oregon," p.3, JLB Papers, Box 6, "Oregon Contraception Law" folder.

${ }^{56}$ Brodie, "Birth Control," JLB Papers, Box 7, "Birth Control Articles" folder.

${ }^{57}$ Brodie, OHS Interview, p.2, 1978. Within two years after this law was put into effect, Idaho, and twentysix other states, followed suit and passed a law nearly identical to Oregon's. Surrounding states recognized how rigorous the standards for contraceptive manufacture were in Oregon and modeled their birth control laws after this 1935 legislation. Oregon Social Hygiene Society, p.4, JLB Papers, Box 6, "Contraception History" folder; Idaho Contraception Law 1937, JLB Papers, Box 5, "Planned Parenthood" folder; Idaho Contraception Law 1949, JLB Papers, Box 5, "Planned Parenthood" folder; Letter from Miren Artiach, State of Idaho, 9/11/85, JLB Papers, Box 5, "Planned Parenthood" folder.

58 "The History and Present Status of Contraception in Oregon," Draft Copy, p.2, JLB Papers, Box 6, "Oregon Contraception Law" folder.
} 
were selling either to retail drugstores or directly to physicians. ${ }^{59}$ Retailers could apply for licenses only if they employed at least one registered pharmacist and if they sold the contraceptives solely at the drug counter. ${ }^{60}$ The law also established strict procedures for testing and manufacture of contraceptive devices in the State of Oregon. Licensed retailers would only be able to sell products that passed Oregon's rigorous testing "respecting grade and quality." ${ }^{, 61}$ If a product did not make the annual list of Prophylactic and Contraceptive Products That Have Passed the Oregon Board of Pharmacy Test and May Be Sold in Oregon By Legally Licensed Outlets, published by the Oregon Board of Pharmacy, then it was illegal to sell them, even in licensed facilities. Chapter 126 also made it illegal to advertise birth control products anywhere other than in medical or drug publications so that the only people who could access this contraceptive information were physicians and those in the "drug trade," or patients who had literature about the drug from the original packaging. ${ }^{62}$ The intention of these restrictions was to keep contraceptives and information about them out of the hands of those who the state deemed inappropriate, namely unmarried women and prostitutes.

A year after this 1935 law was put into effect in Oregon, the birth control movement had a major victory at the national level. In 1873 Anthony Comstock had lobbied to Congress to get a set of laws passed that made mailing any type of birth control information an obscene, illegal act. Margaret Sanger and others tested this law frequently, facing the consequences that went along with civil disobedience, including

\footnotetext{
${ }^{59}$ Chapter 126, Oregon Laws, 1935, p.1, JLB Papers, Box 6, "Oregon Contraception Law” folder.

${ }^{60}$ Ibid.

${ }^{61}$ Ibid., 2.

${ }^{62}$ Ibid., 2.
} 
imprisonment. In 1932, Sanger had a package of contraceptives sent to her in New York, where they were promptly seized by customs. At the suggestion of her attorney, Sanger had another package of contraceptives sent to Dr. Hannah Stone, a gynecologist, in an attempt to "stage a clear case on medical exemption." ${ }^{\prime 63}$ Dr. Stone filed the suit, U.S. v. One Package Containing 120, more or less, Rubber Pessaries to Prevent Conception, seeking to exempt doctors from the Comstock laws so that they could provide birth control "in cases where it would not be desirable for a patient to undertake a pregnancy" and when it was "necessary for the health of women..."64

In 1936, three years after the lawsuit was filed, the United States, Second Circuit Court of Appeals, in New York decided in favor of Stone. The decision stated that the Comstock Laws certainly were not meant to

prevent the importation, sale or carriage by mail of things which might intelligently be employed by conscientious and competent physicians for the purpose of saving life or promoting the well being of their patients. ${ }^{65}$

Sanger quickly made known to supporters that birth control was now legal and that physicians could now give contraceptive advice freely in their clinics, whether public or private practice, in order to "contribute to the health and well being of the nation." Sanger implored supporters around the country to now shift attention from a national level, down to a state level, and begin putting "pressure on public health officials and the establishment of clinics. ${ }^{, 67}$ In addition, she called for local organization of women's groups to help in both establishing clinics and pushing for public health support of birth

\footnotetext{
${ }^{63}$ Ellen Chesler, Woman of Valor: Margaret Sanger and the Birth Control Movement in America (New York: Anchor Books, Doubleday, 1992), 372.

${ }^{64}$ Pamphlet, "Is Birth Control Now Legal?" p. 3, JLB Papers, Box 6, "Oregon Contraception Law" folder.

${ }^{65}$ Ibid., 7.

${ }^{66}$ Letter from Margaret Sanger, 2/4/37, JLB Papers, Box 6, "Oregon Contraception Law" folder.

${ }^{67}$ Letter from Margaret Sanger, 2/2/37, JLB Papers, Box 6, "Oregon Contraception Law" folder.
} 
control services "on a comprehensive scale." ${ }^{\prime 68}$ Brodie knew of this significant stride in the birth control movement because of her local association with the NCFLBC and the information they sent in their newsletters and pamphlets, but this story was not directly discussed within the local media. This was a deviation from the normal birth control savvy Portland media outlets had practiced since 1915, but they gave plenty of press to the more significant decision that followed this case.

Just six months after the U.S. v. One Package decision, in June of 1937, the next extremely important advance in the national birth control movement came about when the AMA officially recognized birth control as "a legitimate part of medical practice." Contraceptive advocates were thrilled with this decision and saw it as a major achievement for their cause. The AMA stated that "voluntary family limitation is dependent largely on the judgment and wishes of individual parents" and that now, under federal laws, physicians could "give information concerning contraception when required to meet the medical needs of patients." ${ }^{70}$ In response to this momentous action by the AMA, Sanger announced, only one month later, "the dissolution of the National Committee [on Federal Legislation for Birth Control], "its work accomplished."”71 As these significant accomplishments in birth control were happening at the national level, Brodie used them as fuel to continue her trudging effort to try to establish a contraceptive clinic in Oregon, alas, to no avail. The board of the Mental Hygiene Society, a division of the Multnomah Medical Society, held firm with the decision that a

\footnotetext{
${ }^{68}$ Letter from Margaret Sanger, 2/4/37, JLB Papers, Box 6, "Oregon Contraception Law" folder.

${ }^{69}$ American Medicine Accepts Birth Control, American Birth Control League, reprinted from the Birth Control Review, June 1937, p.1, JLB Papers, Box 6, "Contraception History" folder.

${ }^{70}$ Ibid., 2.

${ }^{71}$ Chesler, Woman of Valor, 374.
} 
birth control clinic was not necessary or possible at the time. They concluded that because the proposal of such a clinic would require it to be affiliated with the Medical School Clinic. But because the clinic operated on public funding, "no such alliance would be possible." ${ }^{72}$ In addition, the committee at the Mental Hygiene Society explicitly denounced "the less intelligent classes" stating that if they were to have access to such a service, this group of people would handle the advice given with the same "lackadaisical attitude" with which they handled their personal problems. ${ }^{73}$ This particular statement illustrates the eugenic attitude of many of the medical committees of the day, especially in Oregon. Their negative view of patients from the lower economic sectors of society drove their opinions toward establishment of contraceptive services for this "inferior" demographic. The Mental Hygiene board and the Public Health and Hygiene committee, both affiliated with the Multnomah Medical Society, agreed that underprivileged people in Oregon did not need a clinic specifically for their contraceptive needs at that point, and to promote a clinic such as this "before its time is ripe, would be to hinder its eventual accomplishment. ${ }^{.74}$

Positively, for Brodie and her birth control colleagues, the board did agree that it would be beneficial to establish a "family consultation service" "with the exception of the family limitation section, and hope that section might develop later, quietly, as an outgrowth of the unit.." ${ }^{75}$ In other words, the board thought that if a family consultation clinic was established at that particular point, excluding the family limitation piece, that

\footnotetext{
${ }^{72}$ Letter from Inez Goltra Gilbert, 12/8/36, p.1, JLB Papers, Box 6, “Contraception History” folder.

${ }^{73}$ Ibid.

${ }^{74}$ Ibid.

${ }^{75}$ Ibid., 2.
} 
eventually birth control could be casually inserted to the program with little public knowledge or potential for objection. Additionally, they agreed that social workers should still refer patients to the Medical School Clinic when they were not able to pay, as they did not believe that many physicians in the Portland area would be amenable to providing contraceptive advice at a reduced fee. They also stated that it would be valuable for a group such as Brodie's to write to similar groups in other states to obtain "any statistical data they have on the benefit to the communities of such clinics, particularly as to whether any problems of over-population or family dependency were solved thereby." $" 76$

Brodie had the support of many women in the community who were interested in aiding the economically disadvantaged through the Depression by way of controlling the size of their families, but the professional medical community did not want to popularize birth control through establishment of a clinic specific to contraceptive needs. Instead they chose to deny Brodie's proposal and to maintain the limited welfare funded clinics and leave contraception in the hands of private physicians. By 1938, when Brodie received a letter from the Tennessee League of Women's Voters supporting Oregon's efforts toward birth control, but politely denouncing the possibility of the effort in their own region because their local league deemed birth control "outside the scope" of their program, it seemed that for the time being, establishment of a birth control clinic in Oregon was not possible. ${ }^{77}$

\footnotetext{
${ }^{76}$ Ibid., 2.

${ }^{77}$ Letter from TN League of Women Voters, 9/5/38, JLB Papers, Box 6, “Contraception History” folder.
} 
Due to seemingly declining interest of local supporters after the denial from the Multnomah Medical Society, Brodie did not succeed in opening a birth control clinic in the 1930's, but this disappointment did not stop her from maintaining a public persona or from getting additional controversial legislation passed in the State of Oregon. Proud of her association with the Oregon Social Hygiene Society since her experimental biology teaching days, Brodie took up their cause to attempt to reduce syphilis infections through the passage of marriage bills in 1930 and 1938.

The 1930 marriage bill, required that men be tested before marriage, but had no such provision for women. Physicians in the state criticized this legislation by commenting that "the ladies evidently are above suspicion and it [the 1930 law] is not concerned whether they scatter venereal infection or not," implying that men were not the only ones practicing sexually promiscuous behavior and women should practice sexual responsibility as well. ${ }^{78}$ With the prevalence of syphilis as their main argument, the Oregon Social Hygiene Society proposed a new bill in 1935 that required both men and women be tested. They reported that syphilis was the fourth leading cause of death and that the marriage law would help to curb some of the problem by identifying the disease preemptively, especially the "symptomless carrier." $"$ Officials from the City of Portland and the Oregon Hospital put their full support behind this bill illustrating that women could spread syphilis not only to her sexual partner, but also to her offspring. The physician from Portland deemed the 1930 law "ineffective" and estimated that if this new

\footnotetext{
${ }_{78}^{78}$ Oregon State Hospital, 2/10/37, p. 1, JLB Papers, Box 6, "Contraception History" folder.

${ }^{79}$ Material prepared for the Governor's Interim Committee, p.4, Reasons for and Examination for Marriage Law, JLB Papers, Box 6, "Contraception History" folder. Syphilis was fourth, only behind tuberculosis, cancer, and pneumonia.
} 
bill passed "half the cases in women and one-fourth of the cases in men would never occur" and congenital syphilis cases would decrease dramatically. ${ }^{80}$ This marriage bill, the one Brodie was most involved with, passed in 1938 requiring a physical for both males and females, "including a Wassermann test, an examination for gonorrhea or any hereditary mental disease, and a three-day waiting period." ${ }^{, 81}$

Shed in the light of syphilis prevention alone, the marriage bill that passed in 1938 could be interpreted as a positive stride in public health, but it also served to "prevent the marriage of persons whose progeny is very likely to become wards of the state. ${ }^{, 82}$ This provision of the law was heavily endorsed by eugenics supporters as they sought to "reduce the number of physically and mentally handicapped children born each year in Oregon," which they believed in turn would limit "juvenile delinquency," thereby limiting the amount of inmates in state institutions. ${ }^{83}$ The law required an in depth exam that sought to determine whether both parties applying for marriage were "fit to enter into the marriage contract." ${ }^{\prime 84}$ Physicians administering this exam were required to ask several pages of invasive questions and perform a blood test in order for a couple to obtain a marriage license. Then, if they were granted a marriage license, the couple could marry three days later. The questionnaire was written and distributed by the State Board of Eugenics, where the completed pre-marriage exams were returned upon completion.

This process made obtaining a marriage license in Oregon increasingly difficult during this period. Brodie explained that many people who did not want to go through

\footnotetext{
${ }^{80} \mathrm{Ibid}$.

${ }^{81}$ Brodie, Dr. Jessie, 107.

${ }^{82}$ Marriage Exam, p.1, JLB Papers, Box 6, "Contraception History" folder.

${ }^{83}$ Marriage Examination Bill Report, JLB Papers, Box 6, "Contraception History" folder.

${ }^{84}$ Marriage Exam, p.1, JLB Papers, Box 6, "Contraception History" folder.
} 
this process simply crossed the river to Vancouver, Washington where there was no premarital examination law in existence, but where they risked being identified with the stigma of a runaway marriage. ${ }^{85}$ Many decided to take the risk of a "Gretna Green," or runaway marriage, so that they could marry whom they wanted without being subjected to intrusive physical and mental testing and a three-day waiting period. In January of 1939 , the month after this law went into effect, Multnomah County only reported issuing sixty-four marriage licenses, in comparison with Vancouver, Washington's Clark County reporting three hundred twenty-six marriage licenses issued in the same month. ${ }^{86}$ Washington only saw these benefits from the Oregon law until their legislature passed a similar "gin marriage law," to prevent impulsive marriages derived out of alcohol induced engagements, in 1939. These types of marriage laws were not uncommon at all; in fact Oregon and Washington were really just following what was a legislative trend throughout the nation, with more than twenty-five states already with similar laws in effect. ${ }^{87}$ Most required physical examinations, specifically aimed at syphilis prevention, and the three-day waiting period to ensure both parties were in a sound state of mind when they married. In the states where these marriage laws were in effect there was public criticism, but many, just as Oregonians had before the law in Washington, simply went to a nearby state that did not require physical examinations or a three-day waiting period before marriages could be performed.

\footnotetext{
${ }^{85}$ Brodie, Dr. Jessie, 107.

86 "January Wedding Permits at New Low; Washington License Sale at Highest," The Oregonian, January 31, 1939. http://infoweb.newsbank.com.proxy.lib.pdx.edu/iwsearch/we/HistArchive/?p_product=EANX\&p_theme=ahnp\&p_nbid=R63P4FUNMTMyNzE4NTczMC41 MTA1MzI6MToxMzoxMzEuMjUyLjk2LjI4\&p_action=doc\&s_lastnonissuequeryname $=3 \& d$ _viewref $=$ sea rch\&p_queryname $=3 \& p \_$docnum=278\&p_docref $=$2 $2: 11$ A73E5827618330@EANX12A5AF5051029360@2429295-12A072BA4410771A@9-12A605EB6D19F41A

${ }^{87}$ Marriage Examination Bill Report, p.2, JLB Papers, Box 6, "Contraception History” folder.
} 
Brodie's support of this law would signify that she was aligned with eugenic ideals of the day, but it is arguable that her motives for involvement with these issues were in fact, not necessarily eugenic. She was a member of the Oregon Social Hygiene Society from nearly the beginning of its existence in Oregon. Her early involvement with the experimental biology program in Newberg enabled her to become a member of their board, which over the course of her career she was quite proud of ${ }^{88}$ Social hygienists had some similarities with eugenists, in that they wanted to prevent "the propagation of the unfit," but sought to do so through educational means, not compulsory sterilization. ${ }^{89}$ In other words, eugenic arguments ran the spectrum, and Brodie sided in the interest of empowering individuals, especially women, to make sound reproductive, pragmatic choices, free of the taint of feminism or other threatening agenda like race mixing or social equality. She made no critique, for example, of the overall anti-miscegenation thrust of marriage regulation in the early twentieth century in Oregon or other states with marriage laws that were similar in their requirements for marriage application. ${ }^{90}$

Historian Peggy Pascoe asserts that "the use of marriage licenses to track race had become so commonplace" that even states without specific miscegenation laws required "all marriage applicants" to indicate their "race" or "color" on their application. ${ }^{91}$

Perhaps another reason Brodie does not comment on race is because Oregon's 1938 marriage law does not contain any race requirement in its verbiage, though according to Pascoe it was silently implied in all marriage laws, including Oregon's. It is questionable

\footnotetext{
${ }^{88}$ Brodie, Dr. Jessie, 107.

${ }^{89}$ Explanatory Info, Senate Bill 279, JLB Papers, Box 6, "Contraception History" folder.

${ }^{90}$ Peggy Pascoe, What Comes Naturally: Miscegenation Law and the Making of Race in America (New York: Oxford University Press, 2009), 138-139.

${ }^{91}$ Ibid., 139.
} 
if this was the case with the 1938 law because race is completely omitted from the marriage exam administered by physicians for obtaining a license. ${ }^{92}$ However, though Brodie makes no mention of it, the marriage license clerks may have exercised their power to deny licenses to interracial couples, acting as Pascoe describes "gatekeepers of white supremacy," enforcing miscegenation laws with little or no public attention. ${ }^{93}$

In all of her accessible discussions of the 1938 law Brodie never once mentions the limitation of "feeble-minded" individuals reproductive capacity. Her focus is toward the syphilis prevention provision of the marriage bill, not specifically to prevent "the mentally defective, the insane, and most of the other human mistakes," as the eugenics supporters put it, from marrying and reproducing. ${ }^{94}$ Brodie lent her support in the hope that "the marriage examination requirement would encourage pre-marital counseling by the physician and the giving of contraceptive advice." 95 In other words, she relied primarily on a common sense approach to expertise and heightening medical authority to move the agenda for birth control. As a physician she regularly treated children with congenital syphilis, provided young women with "marriage counseling or contraceptive advice," and cared for a multitude of medical problems for poverty-stricken children and families in her position as examining physician for Portland Public Schools. ${ }^{96}$ Brodie makes clear that it was extremely difficult to treat syphilis, in any form, at this time because penicillin was still in its experimentation stage and not in wide use until the mid-

92 "Outline of Procedure for Making Premarital Examination,” JLB Papers, Box 6, “Contraception History" folder.

${ }^{93}$ Pascoe, What Comes Naturally, 139.

${ }^{94}$ Oregon State Hospital, 2/10/37, p.1, JLB Papers, Box 6, "Contraception History" folder.

${ }^{95}$ Brodie, "Birth Control," JLB Papers, Box 7, "Birth Control Articles" folder.

${ }^{96}$ Brodie, Dr. Jessie, 113. Brodie saw quite the gamut of patients during her lifetime. The cases that she mentioned treating range from horrible scabies infestations and lactose intolerance, to sickle cell anemia and burn victims. 
1940's. Her view was that the marriage bill could help decrease the prevalence of syphilis, increase couples seeking contraceptive advice, which in turn could help women in poverty situations limit or space their children so that they could have wanted children and would be able to better provide for them financially. In other words, she remained aligned with the educational prevention viewpoint expressed by the Oregon Social Hygiene Society that aimed toward gentle regulation of the poor, rather than meeting a new market demand for married couples' control over fertility.

Brodie believed in the sanctity of marriage and motherhood, and supported marriage counseling instead of divorce, but also had views that were progressive for women of the time period. Brodie insisted that it was possible to maintain a professional career, while simultaneously carrying out the role of "wife, mother, and home-maker," though sometimes it was like putting together "the parts of a jig-saw puzzle." ${ }^{.97}$ In order to keep this "jig-saw" together, Brodie believed that there were several factors that women needed to keep in mind as they made career and family decisions. First and foremost she, and others she interviewed, said that a professional woman must have a "comprehending husband," meaning that they must lack the inherent male superiority complex that was typical of the day, and be comfortable with their wives carrying out a professional career. ${ }^{98}$ Brodie surmised that this was easiest when two individuals were from the same "educational and professional standing." 99

\footnotetext{
${ }^{97}$ Marriage-A Home-and a Profession, p.3, JLB Papers, Box 5, "MAN. REPRINTS-JLB" folder. When Jessie and Walter opened up a medical practice out of their home in 1938, and later a shared an office in Northwest Portland, it made Jessie's role as a mother and wife easier, while also reinforcing the equality that existed in their marriage.

${ }_{98}$ Marriage-A Home-and a Profession, p.3-5, JLB Papers, Box 5, "MAN. REPRINTS-JLB” folder.

${ }^{99}$ Ibid., 5.
} 
Jessie and Walter, her husband, had achieved the same level of education, which she found to be essential to the ultimate success of marriage because it reduced feelings of "inferiority on the part of the husband of a professional woman."100 Brodie asserted that she always felt that she was on level footing with her husband and said that women physicians were "privileged in Oregon in being able to work side by side with our men physicians." 101 Had there not been this equality in the Brodie's marriage, Jessie might not have been so confident in her professional life or satisfied with her apparent marital success. The Brodie's marriage appeared to uphold and maintain the historical claims of Oregon's women citizens that the state had equal rights for women and women had "full economic citizenship," even though during this historical period, according to Kimberly Jensen, state lawmakers "passed legislation and judges wrote decisions that reinforced women's separate and second class status as economic citizens."102 Brodie herself most likely would have disagreed with this critique of the myth of gender equality in Oregon and illustrated to naysayers the team that she and Walter made throughout their marriage, in their medical practice and travels, as well as in their home. ${ }^{103}$

In addition to the "comprehending husband," Brodie thought women needed to have an "iron physique and untiring energy," well-trained children, an ability to excel

\footnotetext{
${ }^{100}$ Ibid., 5.

101 Brodie, OHS Interview, 1978, 9.

${ }^{102}$ Kimberly Jensen, "Revolutions in the Machinery: Oregon Women and Citizenship in Sesquicentennial Perspective," Oregon Historical Quarterly, Vol. 110, No. 3 (Fall 2009): 336-361, Academic One File, Accessed April 7, 2012, http://go.galegroup.com.proxy.lib.pdx.edu/ps/i.do?id=GALE\%7CA208131432\&v=2.1\&u=s1185784\&it=r $\& \mathrm{p}=\mathrm{AONE} \& \mathrm{sw}=\mathrm{w}$

${ }^{103}$ Brodie continually mentioned the equality between men and women in Oregon and attributed it to the state's pioneer history. She also mentioned that she and her husband shared some household chores, even from the beginning of their marriage. Brodie specifically mentioned that she resented cleaning floors after her childhood, which her brothers warned Walter about before their marriage, and that he "always grabbed the mop from my hands when he saw me preparing to mop the floor." (Brodie, Dr. Jessie, 14-15)
} 
both in their profession as well as in the home, and "efficient and dependable domestic help." 104 As a medical student and then a physician, Brodie had to rely on housekeepers to help her maintain her home and care for her children. Not all women could do this, especially during the Depression, but the Brodie's scraped together funds so they could have this necessary help, though she did mention that it was "a greatly increased expense" to hire sufficient, dependable women to help. ${ }^{105}$ After working two jobs for several years, she was able to open a clinic in the Brodie home, often working for bartered goods, "milk, fruit, vegetables," and even house painting. ${ }^{106}$ Brodie was excellent at keeping her jig-saw puzzle together seamlessly, by working constantly, but proudly stating she "was glad that [her daughter] did not realize" that she worked. ${ }^{107}$ She walked a fine line here between traditional family and marital values, and the drive to maintain a successful professional career.

Responding to female college seniors who were adamant about pursuing a career rather than marriage, Brodie suggested that the slogan for parents should be "-not trial marriages, not easier divorce-but better preparation for marriage and parenthood."108 Her proposal was that if children were educated by their parents and through college classes, they would be better prepared for the stressors of parenting and maintaining a relationship, and would probably end up with successful marriages and careers. ${ }^{109}$ Brodie also relayed her suggestions for the balancing act of marriage, motherhood, and career

\footnotetext{
${ }^{104}$ Marriage-A Home-and a Profession, p.4, JLB Papers, Box 5, “MAN. REPRINTS-JLB” folder.

${ }^{105}$ Ibid., 11.

${ }^{106}$ Brodie, Dr. Jessie, 71.

${ }^{107}$ Ibid., 79.

${ }^{108}$ Marriage and Parenthood, A Vocation, p.8, JLB Papers, Box 5, “MAN. REPRINTS-JLB” folder. ${ }^{109}$ Ibid.
} 
and told these young women that before they decided to embark on any path they needed to examine the demands that it put on one's life, and assess whether or not they could meet those demands.

Brodie's stance on marriage, motherhood, and a career does not necessarily come from a feminist standpoint; in fact she never defines herself as a feminist, or as part of the women's movement, though she was immensely proud of her work in the birth control movement. According to her, the equality that she enjoyed in her marriage and her career was due to the fact that in the West and in Oregon specifically, men and women were on relatively equal footing. In her view of life, equality between the sexes was normal and she was never met with "any outright discrimination."110 She attributed this to both pioneer women and coeducational schooling, especially in higher education. Nevertheless, from a historian's perspective Brodie very well could be defined as having feminist qualities during a period that somewhat overlapped the first and second waves of feminism, but she was careful to always identify as a professional woman, rather than an activist, even in her affiliations with multiple groups and associations. Brodie managed the balancing act of professional, wife, and mother quite well, as a strong marriage and healthy children were of great importance to her.

If Brodie's ideas converged, even slightly, with any eugenist, it would be Paul Popenoe, not in his career as a "hard-line eugenist" who supported Nazi eugenics, but after his self-reinvention as a marriage expert following World War II, or with his earlier

\footnotetext{
${ }^{110}$ Brodie, OHS Interview, 1978, 9.
} 
affiliation with the social hygiene movement. ${ }^{111}$ Popenoe, most certainly, would not have agreed with Brodie's view on professional work and marriage and would have likely defined her marriage as "abnormal" given his assumption that "normal marriage" required women to stay at home. ${ }^{112}$ Their ideas did parallel and they were in agreement that keys to a strong marriage were coming from similar backgrounds, knowing the fundamentals of biology so as to understand sexual reproduction fully, and participating in marriage counseling in order to maintain marital happiness. These areas where they agreed stemmed directly from their involvement with the social hygiene movement and their ideals of promoting sex education, a "reverence for the married state," and prevention of venereal disease. ${ }^{113}$

Social hygienists believed that they could prevent both pregnancy and venereal diseases through comprehensive, biologically based sex education programs running from elementary school through college. ${ }^{114}$ Eugenists, carrying on the "race-suicide" ideology, promoted both discouragement of reproduction of "inferior stock," negative eugenics, and encouragement of "better stock" to increase family size, positive eugenics. ${ }^{115}$ Most involved in the eugenics movement disliked the birth control movement for the same "antifeminist" reasons that Popenoe did, but there were some

\footnotetext{
${ }^{111}$ Molly Ladd-Taylor, "Eugenics, Sterilisation and Modern Marriage in the USA: The Strange Career of Paul Popenoe," Gender \& History, Vol. 13, No. 2 (August 2001): 298. Popenoe first aligned with the social hygiene movement and then moved more toward eugenics after serving as executive secretary for the American Social Hygiene Association in 1920. His main goal after he joined the eugenic movement was to promote and popularize eugenics, rather than education and scientific research.

${ }^{112}$ Ladd-Taylor, "Eugenics, Sterilisation and Modern Marriage," 306.

${ }^{113}$ Dale L. Womble, "The E.C. Brown Foundation: A Pioneering Enterprise in Family Life and Sex Education," Family Relations, Vol. 32, No. 2 (April 1983): 173.

${ }^{114}$ Brodie, Dr. Jessie, 31-34, 107-108; Brodie, OHS Interview, 1978, 4-6.

${ }^{115}$ Linda Gordon, The Moral Property of Women: A History of Birth Control Politics in America (Urbana and Chicago: University of Illinois Press, 2002), 194.
} 
who agreed with certain aspects, particularly those pertaining to "sex education and freedom of speech on sex issues."116

Popenoe and Brodie would have disagreed quite vehemently concerning the issue of birth control. He "detested birth control's feminist aspect" and believed that it would "foster race suicide" because educated white people would use it more effectively and more often than "inferior" social and racial classes. ${ }^{117}$ This is where Brodie deviates substantially from both the social hygiene and eugenic movements, in that she believed that women should have access to safe, effective birth control in order to prevent conception when women needed to for medical or financial reasons. The "desperate" poor women Brodie had treated during medical school and the Depression helped her understand "Margaret Sanger's concern," and drove her to find a solution for those women who were so poor they could not afford another child, but did not have the means to prevent a pregnancy either. ${ }^{118}$ By stepping around feminism, she gently disarmed some of her potentially strongest opponents, namely sexist and classist male physicians, lawmakers, and eugenists.

She was able to do this through medical and educational means in her practice and role as a physician, where after mornings filled with pediatric cases, her afternoons were filled with "cases of gynecologic problems of young women coming for marriage counseling or contraceptive advice" often for both the "prospective husband and wife."119 Brodie said having both parties entering a marriage come for counseling "promised the

${ }^{116}$ Gordon, Moral Property of Women, 194.

${ }^{117}$ Ladd-Taylor, "Eugenics, Sterilisation and Modern Marriage," 305.

${ }^{118}$ Brodie, "Birth Control," JLB Papers, Box 7, "Birth Control Articles" folder.

${ }^{119}$ Brodie, Dr. Jessie, 113. 
most successful marriage." ${ }^{\prime 120}$ Popenoe would have argued that the counseling was an asset to the impending nuptials, but that birth control was only necessary if the couple in question were from the "inferior" strata of the population. It was Popenoe's intention to increase the birthrate "among the 'better' part of the population through education and counseling. ${ }^{\prime 21}$ Brodie never discussed marriage counseling with these particular eugenic undertones, but did continually put emphasis on "every woman's right to have only the number of children she wants and that she and her husband can feed, clothe, shelter, educate, and, of course, LOVE." 122 Language of rights weaves in and out of Brodie's long trajectory in the field of women's health, and in the early days, as a direct result of practicing medicine during the Depression, she stuck with emphasis on women's ability to afford birth control and children. Ultimately, women could achieve this control of their reproductive capacity, with little economic hindrance, through education and Brodie continued to push for birth control, not only with her patients, but for Oregonians in general.

By the end of the 1930's Brodie was a well-established and respected physician in the Portland area, and was known throughout the area because of her involvement in the birth control movement and various professional associations. Though her attempts to establish a clinic devoted specifically to contraceptive and family counseling were thwarted by both the Multnomah Medical Society and the University of Oregon Medical School, Brodie continued to chip away at the barriers to a clinic periodically throughout

\footnotetext{
${ }^{120}$ Brodie, Dr. Jessie, 113.

${ }^{121}$ Ladd-Taylor, "Eugenics, Sterilisation and Modern Marriage," 308.

${ }^{122}$ Brodie, "Birth Control," JLB Papers, Box 7, "Birth Control Articles" folder.

${ }^{122}$ Brodie, Dr. Jessie, 113.
} 
the next twenty years. The contraceptive legislation she was involved with was some of the most important, locally and nationally, during the 1930's and would remain an asset to the birth control movement in Oregon. Brodie's involvement with organizations devoted to the advancement of women's healthcare during the 1930's led to her increasing public demand and recognition. The next twenty years would take Brodie away from Portland, to locations nationally and internationally, where she continued her commitment to finding solutions for women's control of their reproductive capacity and their health in general. 


\section{CHAPTER 2}

"Service Unlimited”: Representing Oregon Nationally and Internationally

In the 1930's Dr. Jessie Laird Brodie had set out to establish a clinic in Oregon that would be devoted solely to birth control and family planning services. When the Multnomah Medical Society rejected her proposal, she instead succeeded in appealing legislation to the State of Oregon for strict regulation of the manufacture and sale of contraceptives. With this victory under her belt, Brodie put her aspirations for a birth control clinic to the side and began focusing on other local issues regarding women's health that would eventually lead her to audiences nationally and internationally. Brodie's long affiliation with the Oregon Social Hygiene Society provided her with the opportunity to build on the sex education program she was involved with early in her career, and brought her recognition throughout the state. This association throughout the 1940's and 1950's served as a catalyst to Brodie's increased local participation that compounded to gain her national, then international, attention. Her shifting focus from birth control specifically, to women's health, marriage, and education served as stepping stones on the global stage back toward Brodie's ultimate goal of access to contraception for women of all social and financial classes in the United States. Ironically, though birth control and contraception moved very much to the backburner in this era, the local, national, and international medical credibility that she gained enabled her to re-insert reproductive freedom into a renewed feminist medical agenda in the 1960's.

Brodie's involvement with the Oregon Social Hygiene Society, back in the 1920's, as a teacher of experimental biology had instilled in her a firm belief that sex 
education, by direct and explicit means, was the basis for a strong marriage, a healthy sex life, and a "clean and authentic" understanding of reproduction. ${ }^{1}$ These beliefs served as a foundation for Brodie's interest in the birth control movement in the 1930's and the marriage and family planning work that she did in the 1940's. Though a birth control clinic was not a possibility at this particular juncture, Brodie was able to be increasingly involved in sex education curriculum and instruction throughout Oregon through the E.C Brown Trust, an extension of the Oregon Social Hygiene Society.

Dr. E. C. Brown was a founding member of the Oregon Social Hygiene Society, established in Portland in 1911, and he provided them with a yearly contribution of $\$ 5,000$ to keep the society intact after funding waned in the late $1920{ }^{\prime}$ s. $^{2}$ When Dr. Brown passed away in 1939 , he left $\$ 500,000$ for the establishment of "a perpetual charitable trust" that would "carry on the instruction and education of the boys and girls and young people of the State of Oregon in respect to what is commonly called social hygiene" or sex education. ${ }^{3}$ The purpose of the trust was to provide the proceeding generations of Oregonians with a:

sound and healthy view and understanding in respect to sex, sex relations and marriage, and also as to the perils of venereal diseases and other evils which result from sexual abuses and errors, in order that they may be brought to appreciate the importance of leading clean and wholesome lives sexually. ${ }^{4}$

Brown designated the President of the University of Oregon as the Administrator of the trust as he assumed that whoever was in that position would have "the breadth of

\footnotetext{
${ }^{1}$ Marriage and Parenthood, A Vocation, p. 4, Jessie Laird Brodie Papers, Box 5, "MAN. REPRINTS-JLB" folder, Legacy Center, Drexel University College of Medicine (hereafter JLB Papers).

${ }^{2}$ Curtis E. Avery, "Toward an Understanding of Sex Education in Oregon," The Coordinator, Vol. 5, No. 1 (September 1956): 1, 3; Dale L. Womble, "The E.C. Brown Foundation: A Pioneering Enterprise in Family Life and Sex Education," Family Relations, Vol. 32, No. 2 (April 1983): 175.

3 Avery, "Toward an Understanding," 3.

${ }^{4}$ Ibid.
} 
understanding and the depth of educational experience" to carry out the role to Brown's specifications, though he did not "impose narrow restrictions" as to how this education should be executed, presumably to allow for change in society and sex education in general. ${ }^{5}$ Brown's vision for the trust influenced his decision to omit specific operational guidelines in that "he envisioned the trust's activities as being focused on 'that fine-edge of exploration,' experimenting with new concepts and methods" before they gained recognition or acceptance elsewhere. ${ }^{6}$ This vision for sex education was a new concept that originated in Oregon, but quickly fanned out across the U.S., and eventually internationally.

The first director, Dr. Donald M. Erb, assumed the position with some uncertainty and trepidation, and promptly began a study as to how social hygiene education was interpreted and how to implement the sex education provisions of Dr. Brown's will. Erb's conclusion was that "so-called sex education basically meant education with respect to reproduction, an essential part of the study of biology," so he thought it prudent to "place responsibility for carrying out the terms of the Brown Will" at the University of Oregon Medical School as they offered a scientific, medical setting. ${ }^{7}$

Dr. Adolph Weinzirl, the second director, defined social hygiene as "two separate and distinct parts or 'phases'," sex education and venereal disease education. ${ }^{8}$ Within these designations there were three sources of sex education: the home, the church, and the school. In the home, sex education was the day to day example set by parents for

\footnotetext{
${ }^{5}$ Ibid., 4.

${ }^{6}$ Womble, "The E.C. Brown Foundation," 174.

${ }^{7}$ Avery, "Toward an Understanding," 4.

${ }^{8}$ Ibid., 5.
} 
their children. Weinzirl believed the experience that children had in their homes set the "pattern for the child's ideals and expectations" for marriage and sexual relationships. ${ }^{9}$ The church's role was to "provide certain ethical motivations with respect to the exercise of the sex instinct," primarily through the marriage ceremony, and the emphasis on monogamy. ${ }^{10}$ In addition to these two sources was the role of the school in sex education. Weinzirl specifically stated that the school should "not be asked to take the place of the church and the home" because he felt that it was "not equipped" to meet the same goals. ${ }^{11}$ Instead, the role of the school was limited to providing "scientific data pertaining to sex" and ingrained in the regular curriculum of "science, biology and nature-study" because this education was not able to be conveyed through the home or the church. ${ }^{12}$ Though the role of the public schools in sex education was limited to scientific data only, they were entirely responsible for venereal disease education, as it was a public health issue. In some ways, these early reforms were a method for a new generation of scientists, health professionals, and educators to claim authority over the social domains of women and children's health and reproductive politics, that were traditionally the responsibility of both the clergy and the family.

In 1945, Weinzirl successfully influenced the Oregon State Legislature to pass a law making "health and physical education required subjects in all the State of Oregon's public schools in all 12 grades."13 This allowed sex education to entrench in all public school curriculums and in 1947 Oregon schools showed the "first classroom sex

\footnotetext{
${ }^{9}$ Ibid., 5.

${ }^{10}$ Ibid., 6.

${ }^{11}$ Ibid., 6.

${ }^{12}$ Ibid., 6.

${ }^{13}$ Womble, "The E.C. Brown Foundation," 176.
} 
education movie in the U.S.A. entitled 'Human Growth'," which some called "the most important contribution to sex education in the United States." ${ }^{14}$ The film focused on physical, physiological, social, and psychological aspects of sex, in order to emphasize family values, child rearing, and human relationships "in a calm, matter-of-fact way."15 Parents responded well to the film stating that it was "a great need—so many parents are not capable of presenting the question in such a sensible and unbiased manner." ${ }^{16}$ One major concern was that the film did not put emphasis on the moral side of sex, but the E.C. Brown Trust intended it to serve as a jumping off point for the discussion of sex to happen with the parents in the home and through the church. The film quickly gained national attention and received many requests for rent throughout the nation. With this success, the E.C. Brown Trust put Oregon on the map as a pioneer in the field of sex education in public schools.

Indeed, an important aspect of this film's success was its rapid adoption through national and international medical networks eager to deploy new popular technology to bolster their expertise in the post-war era. ${ }^{17}$ The film received national and international awards and recognition, helping expand Oregon's innovative brand of sex education to twenty countries and millions of students around the world. ${ }^{18}$ Due to the heightened global consciousness brought on by the cataclysms of World War II, health and medicine

\footnotetext{
${ }^{14}$ Womble, "The E.C. Brown Foundation," 176; Avery, "Toward an Understanding," 8.

15 "Sex Education Film for Teen-Agers Winning High Praise from Oregon Mothers and Teachers," Oregon Journal, April 7, 1948, JLB Papers, Box 6, "E.C. Brown Trust” folder.

${ }^{16} \mathrm{Ibid}$.

${ }^{17}$ Jennifer Morris, "'I Knew the Kind of Work that was Done for Children': Dr. Martha Eliot and the Origins of UNICEF," in Women and Transnational Activism in Historical Perspective, edited by Kimberly Jensen and Erika Kuhlman, (Dordrecht: Republic of Letters Publishing, 2010), 219-220.

${ }^{18}$ Womble, "The E.C. Brown Foundation," 176; "Human Growth (1947)," The U of O Channel, University of Oregon, 2010, Accessed April 8, 2012, http://media.uoregon.edu/channel/2012/04/03/human-growth$1947 /$.
} 
overall took an international turn. ${ }^{19}$ This mid-century internationalism had roots, of course, in the earlier internationalist movement following World War I, driven by a feminist agenda and with the

concept that women physicians working together above and across nation-states could best develop ideas and take action to resolve global problems of disease, war, and inequality. ${ }^{20}$

Essentially this earlier internationalism was geared toward promoting the "health and safety of women and children" in an attempt to create "healthy communities and nations, and a world without war." 21 This renewed postwar internationalism contributed to the ability of a sex education film from Oregon to have this type of international currency, and in the late 1940's helped pull Brodie into this international fray via professional development and educational interests. Ultimately this sex education film gave local physicians a potential global currency and status.

The vision for the E.C. Brown Trust aligned almost perfectly with Brodie's own long-standing beliefs on the importance of sex education for young people, justifying her continuing support and involvement with the nascent organization, and now offered a transnational dimension as well. Brodie had known Dr. Brown, characterizing him as "dedicated and very helpful" in regard to his work with the Oregon Social Hygiene Society, when she was teaching experimental biology and later while advocating for a

\footnotetext{
${ }^{19}$ See: Leila J. Rupp, "Constructing Internationalism: The Case of Transnational Women's Organizations, 1888-1945," The American Historical Review Vol, 99, No. 5 (December 1994): 1571-1600; Morris, "I Knew the Kind of Work," 219-238.

${ }^{20}$ Kimberly Jensen, "Feminist Transnational Activism and International Health: The Medical Women's International Association and the American Women's Hospitals, 1919-1948," in Women and Transnational Activism in Historical Perspective, edited by Kimberly Jensen and Erika Kuhlman, (Dordrecht: Republic of Letters Publishing, 2010), 144.

${ }^{21}$ Ibid., 145.
} 
birth control clinic and the contraceptive legislation that passed in $1935 .{ }^{22}$ Throughout the 1940's Brodie received invitations to lecture on sex education around Oregon. Her focus usually remained on sex education as it pertained to relationships between women and men and "personal attitudes and adjustments toward marriage." ${ }^{23}$ Sometimes her direct approach to the explanation of the reproductive system and cycle was not met with enthusiasm, but most often even conservative critics admitted to Brodie that the lectures were "good for the young folks." ${ }^{24}$ She was proud to be a part of this group and of the information she was able to provide to young people with the sex education curriculum, continuing her participation with the Trust throughout the next forty years.

Brodie's affiliation with the E.C. Brown Trust and the Oregon Social Hygiene Society led to her involvement with the Hazen Conferences and the Pacific Northwest Conference on Family Relations, both during the 1940's. The Hazen Conferences were an "annual series of one-week retreats for professionals in the field of peace and social welfare problems." ${ }^{25}$ Brodie was invited to participate in the three conferences that were held on the West Coast in the 1940's, all of which placed particular emphasis on familial relationships and marriage.

At the 1946 Hazen Conference, Brodie took away information concerning student guidance on both marriage and family life, as marriage counseling and strengthening had become a part of both her medical practice and activism. This group suggested, as Brodie believed, that marriage should be a "partnership" on sexual, economic,

\footnotetext{
${ }^{22}$ Jessie Laird Brodie, M.D., "Dr. Jessie”: The Odyssey of a Woman Physician (Portland: Carolina Pacific Publishing, 1991), 108.

${ }^{23}$ Letter to Elmo Stevenson, 11/2/48, JLB Papers, Box 6, "E.C. Brown Trust" folder.

${ }^{24}$ Brodie, Dr. Jessie, 108.

${ }^{25}$ Ibid., 88.
} 
intellectual, and spiritual levels. ${ }^{26}$ In their explanation of how an ideal marriage should look they iterated that the economic contribution of women varied from marriage to marriage, but Brodie continued to firmly believe that it was possible to maintain a marriage, family, and profession if so desired. ${ }^{27}$ To achieve this "partnership" required a level of maturity on the part of young couples which the Hazen guide said was not always present. Brodie found this to be true in her practice stating, "So often young people are entering marriage without an understanding of the emotional adjustments that must be mutually made in order to make their alliance permanent." 28 If there was this understanding then the couple in question would have a stronger marriage and be better parents.

Along similar lines, Brodie was also a participant in the Pacific Northwest Conference on Family Relations, both in 1945 and 1947. The 1945 conference was held in Vancouver, B.C. where Paul Popenoe was the featured speaker. Popenoe was recognized throughout the country as the founder of modern marriage counseling. His interests concerning marriage counseling came from his involvement with the eugenic movement and the implementation and promotion of "positive" eugenics after the Second World War. The intent of the "positive" eugenic movement was to counsel young people on how to select a "eugenically fit mate" and promote procreation in these unions, and to counsel married couples to "preserve and protect their marriage and family." 29 His

\footnotetext{
${ }^{26}$ The Hazen Conferences on Student Guidance and Counseling, 1946, JLB Papers, Box 6, "E.C. Brown Trust" folder.

${ }^{27}$ Ibid.

${ }^{28}$ Marriage and Parenthood, A Vocation, p. 2, JLB Papers, Box 5, "MAN. REPRINTS-JLB" folder.

${ }^{29}$ Wendy Kline, Building a Better Race: Gender, Sexuality, and Eugenics from the Turn of the Century to the Baby Boom, (Berkeley, Los Angeles, London: University of California Press, 2001), 124.
} 
address at the 1945 conference focused on counseling for marital satisfaction so as to avoid marriage failure, which would in turn keep the middle class family intact. ${ }^{30}$

Paralleling this movement toward "positive" eugenics, birth control advocates began "a campaign to strengthen the American family," considered newly fragile and vulnerable in an internationalist, nuclear age. ${ }^{31}$ This group argued that "birth control would produce "wholesome family life" through premarital counseling and sex education. ${ }^{32}$ In 1942, the Birth Control Federation of America changed their name to Planned Parenthood Federation of America (PPFA) to reflect their claim that "family planning would strengthen the family." 33 To carry out their family planning initiatives PPFA started their own Marriage and Education Counseling Program in 1947, focusing on "child spacing and family size" by use of contraception and "good mutual sexual adjustment," as the means to maintain a happy, healthy marriage. ${ }^{34}$ At the same time PPFA was using these shifts in ideology to "move away from the feminist and leftist origins of the birth control fight" and align itself with the professionals that had greatly influenced the movement in the 1930's. ${ }^{35}$ Brodie's intentions in her own marriage counseling remained aligned not with eugenics, but with the increasing professionalization of the birth control movement. Her goals were not to promote the growth of a particular class of people, but to educate young couples on contraception and the type of "partnership" approach to marriage that the Hazen Conferences promoted.

\footnotetext{
${ }^{30}$ Highlights of the Pacific NW Conference, JLB Papers, Box 6, "Northwest Conference on Family Relations" folder.

${ }^{31}$ Kline, Building a Better Race, 132.

${ }^{32}$ Ibid., $132,143$.

${ }^{33}$ Linda Gordon, The Moral Property of Women: A History of Birth Control Politics in America, (Urbana and Chicago: University of Illinois Press, 2002), 242.

${ }^{34}$ Ibid., 243, 259.

${ }^{35}$ Ibid., 242.
} 
Ultimately Brodie believed that this approach would make for a strong family and a healthy marriage which could, for those who chose to, allow more women professionals to continue their careers.

As the president of the committee for organizing the 1947 Pacific Northwest Conference on Family Relations, Brodie and the board decided that the conference in Portland would carry the theme of "Strengthening Family Living in the Northwest," and would be "primarily a conference for...interested professional groups rather than an attempt to stimulate popular interest in family relations." ${ }^{36}$ Participants presented information pertaining to family life from marriage counseling and family living education at multiple grade levels, to nursery school education and preparation for fatherhood. ${ }^{37}$ Their sponsors included the E.C. Brown Trust, the Oregon State Board of Health, and the Multnomah County Health Council, but did not include the Oregon Eugenics Society. Clearly the agenda of this particular conference on Family Relations was not eugenic in nature, but specifically focused on the educational aspects involved with the strengthening of family life in the Northwest. ${ }^{38}$

As a result of this Conference in Portland there was an increased interest in establishing family counseling services for Portland and the surrounding communities because of the attention and emphasis of the necessity that conference presenters placed on this issue in the broader national context. Portland was "one of the very few cities of its size" in the country that did not have a "specialized private family counseling

\footnotetext{
${ }^{36}$ Letter to Organizations Interested in Improving Family Relations, 12/26/46, JLB Papers, Box 6, "Northwest Conference on Family Relations" folder.

${ }^{37}$ Pamphlet, $9^{\text {th }}$ Annual Meeting, Pacific Northwest Conference on Family Relations, 1947, JLB Papers, Box 6, "Northwest Conference on Family Relations" folder.

${ }^{38}$ Ibid.
} 
agency." ${ }^{39}$ In the 1930's Brodie had been on a committee, sanctioned by the Multnomah County Medical Society, to investigate the possibility of establishing a family counseling service, with public funds, for the underprivileged population in Portland. A committee was selected, and the research was completed, with proposals for coordination across educational fields, but somehow fell by the wayside until 1946, when the Commission on Christian Family Living of the Portland Council of Churches again inquired about this resource. ${ }^{40}$ Another full investigation, through the Family and Child Welfare Division in Portland, including responses from the community and professionals, was completed but again appears that a central agency did not come to fruition. They did receive some positive feedback but suggested that services at smaller existing agencies be "expanded to the extent necessary to meet the problem" of waning family values. ${ }^{41}$ After this report it appears that work in the community regarding education concerning marriage and family remained the responsibility, in limited quantities, of "public and private social agencies and by churches in their counseling function." ${ }^{42}$ Brodie continued to offer marriage and contraception counseling services in her clinic until she retired in 1960, putting her special stamp of medical expertise in family planning on her practice in the Portland community.

\footnotetext{
${ }^{39}$ Council of Social Agencies, 7/29/48, Proposed Plan for Community Counseling Center, p.2, JLB Papers, Box 6, "Northwest Conference on Family Relations" folder.

${ }^{40}$ Report of the Committee, Appointed to Study the Possibilities for Comprehensive Program of Family Education in Portland, OR, JLB Papers, Box 6, "Northwest Conference on Family Relations" folder; Minutes of Meeting, Commission on the Christian Family of Portland Council of Churches, 11/13/46, JLB Papers, Box 6, "Northwest Conference on Family Relations" folder.

${ }^{41}$ Summary of Replies to Mrs. Skelley's Letter on the need for a family agency, JLB Papers, Box 6, "Northwest Conference on Family Relations" folder.

${ }^{42}$ Council of Social Agencies, 7/29/48, JLB Papers, Box 6, "Northwest Conference on Family Relations" folder.
} 
Brodie's increased role in the local medical community gained her praise and recognition, shown by her nomination as President of the Pacific Northwest Conference on Family Relations and later as President of the Portland Chapter of the United Nations Association, an index to the increasing interest in internationalism in the city, that led to her involvement with these organizations at the national level and then quickly to the global stage. In 1945 Brodie attended the Pan-American Pediatric meeting in Washington, D.C. where several of the participating women physicians observed that "foreign women physicians attending as delegates had little opportunity to become acquainted with other women delegates. ${ }^{, 43}$ One of the local Washington woman physicians decided in light of this observation she would invite these women physicians from various Latin American countries, most notably Mexico, to her home for a dinner party. As these women visited and got to know one another they devised the idea of creating a Pan American Medical Women's Alliance (PAMWA). Their specific purposes for forming were threefold:

to provide an opportunity for medical women of all of the republics of the Western Hemisphere to interchange scientific knowledge; to discuss medical-social problems of special significance to women and children; and to forge links of friendship, mutual help, and understanding between the women physicians of the Americas. ${ }^{44}$

Maternalist in nature, PAMWA's purposes had different meanings for the women from North and South America. The women physicians from North America observed that the Latin American "doctora's training was less intensive" than theirs, and because women had only been "permitted to study medicine" for a short period of time in Latin America, the physicians from the northern hemisphere tended to have a great deal more

${ }^{43}$ Brodie, Dr. Jessie, 122.

${ }^{44}$ Our Alianza and How it Grew, 1946-1979, PAMWA Congress XVI, Sept. 1979, p.1, JLB Papers, Box 7, "Manuscripts" folder. 
experience in both years and medical practice. ${ }^{45}$ Brodie explained that Latin American doctors were not accustomed to presenting professional papers regularly and the women from North America made it a priority in their friendships with the doctoras to "give them advice as to...reading and writing medical papers. ${ }^{, 46}$ The Latin American doctoras had a "particular interest in the problems of women and children," and sought not only to address concerns of "health, nutrition and welfare of their women and children," but also to somehow encourage more women in their countries to practice medicine. ${ }^{47}$

In 1947, Brodie traveled to Mexico City to attend the First Congress of the Pan American Medical Women's Alliance, where she called the opening, with two hundred participating women physicians, "most impressive." ${ }^{48}$ This first meeting of PAMWA was both a professional and social experience for those involved as the North American doctors were treated to multiple facets of Mexican culture when papers were not being presented. Brodie noted that most of the papers presented by the Latin American physicians were "medical social" because "conditions in these countries make much more government medicine necessary," but the papers presented by the North Americans were more scientific in focus. ${ }^{49}$ On a socio-cultural level, the physicians spent a significant amount of time learning how to communicate with each other through language barriers, enjoying the hospitality and cultural customs of their Mexican hostesses, and establishing friendships that they would maintain for many years through

\footnotetext{
${ }^{45}$ Brodie, Dr. Jessie, 123.

${ }^{46}$ Dr. Jessie Laird Brodie, interview by Roberta Watts, Oregon Historical Society, February 14 and March 29, 1978, 11.

${ }^{47}$ The Doctoras of the Americas as a Resource in Family Planning, p.1, JLB Papers, Box 7, "Birth Control Articles" folder.

${ }^{48}$ PAMWA I 1947, p.6, JLB Papers, Box 7, “Autobiographical Material for Book-Dr. Brodie” folder.

${ }^{49}$ Ibid., 8.
} 
the biennial PAMWA Congresses. This professional association also served beneficial for many Latin American women physicians as it "stimulated the organization of national groups of medical women in these countries, who in some cases had previously no knowledge of each other's existence." ${ }^{50}$ As numerous scholars have shown, many of these interactions were characterized by sometimes tense "missionary" attitudes on the part of English speakers, but Brodie was viewed by her PAMWA colleagues as a uniting entity because of her "uncommon ability for establishing human relations" and collaboration across physical and cultural divides. ${ }^{51}$

At the second PAMWA Congress, held in Los Angeles in 1949, with Dr. Elizabeth Mason-Hohl acting as the first president, the organization experienced its first major issue. Mason-Hohl was asked to serve another two years as president of PAMWA, which "aroused some animosity" with both the American and Latin American physicians, because "she was a leader in the birth control clinics and planned parenthood movements in California." 52 The Catholic members of PAMWA were apprehensive to have MasonHohl represent their organization again with her personal values, but they sought to come to a compromise so that all of the women would continue to feel comfortable with the direction PAMWA was going.

In an effort to avoid repetition of past failed attempts at Inter-American organizing, PAMWA organizers were sensitive to regional cultural and political

\footnotetext{
${ }^{50}$ Our Alianza and How it Grew, 1946-1979, PAMWA Congress XVI, Sept. 1979, p.1, JLB Papers, Box 7 , "Manuscripts" folder.

${ }^{51}$ Letter from Tegualda Ponce, 8/14/58, JLB Papers, Box 2, “1958 [2] (Correspondence, Photos, Newsclippings" folder. See Megan Threlkeld, "How to 'Make This Pan American Thing Go?' Interwar Debates on U.S. Women's Activism in the Western Hemisphere," in Women and Transnational Activism in Historical Perspective, edited by Kimberly Jensen and Erika Kuhlman, (Dordrecht: Republic of Letters Publishing, 2010), 173-192, for discussion of Pan-American women's international organization.

${ }^{52}$ Brodie, Dr. Jessie, 128.
} 
differences and sought a more conservative approach to organization with the intent to "facilitate diplomacy by promoting friendship and cooperation" among these medical elite women in a non-political and non-religious context. ${ }^{53}$ A resolution was proposed by Catholic physician, Anita Muhl, stating: “the Pan American Medical Women's Alliance is a scientific organization only and it will not ally itself officially with any political party or religious belief." ${ }^{, 54}$ Brodie explained that it passed unanimously and "served to keep the organization intact" during subsequent conferences when Chilean women were trying to have PAMWA support women's pensions in their home country in 1951 and in 1962 when Dr. Mary Calderone, Executive Director of PPFA, and Dr. Adaline Satterthwaite, a birth control advocate, were planning to present papers concerning contraception. ${ }^{55}$ With this resolution in effect, the scientific information presented at PAMWA Congresses focused on women and children's health from a "medical-social" perspective, often changing by demographic location as each country represented had varying "medicalsocial problems." ${ }^{56}$ The point was to seek out a common ground where medical women from many countries could convene for equal and respectful intellectual and social exchange, rather than follow the model of previous international women's organizations that specifically emphasized U.S. superiority. ${ }^{57}$

Dr. Mason-Hohl also caused some tension between PAMWA and the American Medical Women's Association (AMWA), despite the resolution made by the

\footnotetext{
${ }^{53}$ Threlkeld, "How to 'Make This Pan American Thing Go,"” 190.

54 "Family Planning and Our Latin American Colleagues," JAMWA Vol. 23, No.6 (June 1968): 559, JLB Papers, Box 7, "Birth Control Articles" folder.

${ }_{55}^{55}$ Brodie, Dr. Jessie, 314.

${ }^{56}$ Ibid., 143.

${ }^{57}$ Threlkeld, "How to 'Make This Pan American Thing Go," 191.
} 
organization. Brodie explained that PAMWA was forced to change venues for their fourth meeting because of the resentment and displeasure some Catholic women physicians in AMWA had toward Dr. Mason-Hohl. She described Mason-Hohl as a "very efficient but domineering individual who often presented an abrasive manner, making enemies for herself as well as for the Alliance" and these qualities, along with the fact that she was a birth control advocate in California, created an antagonistic atmosphere which the Catholic physicians did not want to be involved with. ${ }^{58}$ According to Brodie, these animosities were underlying the 1953 PAMWA IV Congress in New York, so as president-elect for PAMWA V, and always with the ambassadorial spirit that was characteristic of and successful for her, she appealed to the members of AMWA at their mid-year session to try to smooth the waters between the organizations.

In her presentation Brodie explained the reciprocally advantageous relationship that PAMWA provided women physicians in North and South America. The North American physicians were gaining an understanding of Latin American cultural values through their visits to doctoras homes and were also obtaining knowledge concerning "tropical disease conditions little known in the U.S." while in South American countries. $^{59}$ Benefits that the Latin American women doctors had through the Alliance were presented in a maternalistic tone, though not meant in a derogatory manner whatsoever, as PAMWA sought to help these physicians with their ability to take a more "active part in medical leadership" in their respective countries. ${ }^{60}$ Brodie iterated that PAMWA offered female physicians from Latin America a chance to participate in

\footnotetext{
${ }^{58}$ Brodie, Dr. Jessie, 163-164.

${ }^{59}$ Ibid., 164.

${ }^{60}$ Letter to Eleanor Roosevelt, 9/20/52, p.1, JLB Papers, Box 5, “Corresp. Eleanor Roosevelt” folder.
} 
leadership roles as well as the "opportunity to prepare and deliver medical papers [and] participate in medical discussions," which many were not able to easily or freely do in their home countries. ${ }^{61}$ In addition, young physicians from Latin America were given the opportunity to come the U.S. to study and complete internships in fully equipped hospitals because "often there was no opportunity for internships for women" in their home countries. ${ }^{62}$ The detailed explanation that Brodie provided for AMWA in her presentation convinced the group to encourage PAMWA and "provide support and hospitality wherever possible." ${ }^{63}$

Potential controversy averted, the fourth congress proceeded with success. The visits made to the United Nations (UN), World Health Organization (WHO), Pan American Sanitary Bureau (PASB), and Medical Women's International Association (MWIA), helped PAMWA gain increased recognition and established affiliations that garnered them both respect and credibility. AMWA's publication, the Journal of the American Medical Women's Association (JAMWA), remained the mouthpiece of PAMWA, devoting a full issue to the Congress each year that the physician's met. Brodie was often either an author of at least one piece or the editor of the volume devoted to PAMWA. Their association with the PASB involved them in public health projects in Latin America to "raise their levels of health," overall. ${ }^{64}$ Additionally, Brodie relayed that PAMWA's continuous involvement with the WHO and the PASB was to extend their "influence to the cause of WORLD PEACE" by promoting the western hemisphere,

\footnotetext{
${ }^{61}$ Brodie, Dr. Jessie, 164.

${ }^{62} \mathrm{Ibid}$.

${ }^{63}$ Ibid.

64 "Pan American Sanitary Bureau Reports Progress and Plans: Long Range Planning of Health Programs in the Americas," JAMWA Vol. 9, No. 1 (January 1954): 13, JLB Papers, Box 7, "Journals" folder.
} 
and the cordiality between North and South America, as an example to the rest of the world. ${ }^{65}$ Couching a potentially feminist agenda in a less controversial message of antiwar sentiment helped PAMWA succeed in bringing attention to the problems of women and children in their respective countries, from a medical, and not directly political, standpoint.

In her presentation to AMWA in 1953 Brodie had mentioned the PAMWA internship program that offered young women doctor's from Latin America the opportunity to study medicine in the United States, a program that she and other North American physicians were proud of and supported generously. At the time of PAMWA's founding, women in Latin America had only recently been able to attend medical school, and as a result, there were limited numbers of medical internships for female students. Brodie recalled that it was "puzzling" to her and other members at the first few PAMWA Congresses because the American physicians would receive dinner invitations from the younger members. ${ }^{66}$ Later they found out that it was because the young women wanted to introduce their parents to the physicians in an attempt to get them to allow their children to travel to the U.S. to complete internship and residency programs, in the spirit of liberal internationalism so characteristic of the post-war period.

Echoing the inclusive spirit of the progressive wing of internationalism, Brodie also explained that PAMWA "showed no discrimination" when selecting students, as evidenced by the case of a twelve year old boy, son of one of the doctoras in Bolivia,

\footnotetext{
65 "Address at Opening Session of Fifth Congress: Pan American Medical Women's Alliance," JAMWA Vol. 11, No. 10 (October 1956): 343, JLB Papers, Box 7, "Journals" folder.

${ }^{66}$ Our Alianza and How it Grew, 1946-1979, PAMWA Congress XVI, Sept. 1979, p.4, JLB Papers, Box 7, "Manuscripts" folder.
} 
who attended school for six years in Arkansas, staying at the home of Dr. Eva Dodge. ${ }^{67}$ Fernando's parents appealed to the members of PAMWA asking if one would be willing to take their son for a couple of years because of the unstable political conditions in Bolivia. They felt that he would be safer in the U.S. than he would be if he stayed with them. After high school he went on to college and law school in Bolivia and served as a U.N. Ambassador, and Brodie noted that PAMWA members were "proud to claim Fernando as a son of our Alianza."68 Both of these examples reveal yet again that PAMWA operated under the auspices of maternalism to cultivate and solidify the relationships between the two regions. Though they never define their intentions in this exact manner, their decision to maintain a specific focus on the problems of mothers and children, as well as the dynamic of "teacher" and "student" that existed between the two hemispheres, placed their agenda loosely within the definition of maternalist feminism that had driven other Pan-American organizations, such as the Pan-American Child Congresses, throughout the first half of the twentieth century. ${ }^{69}$

The professional associations built by PAMWA's members in these early years were beneficial to both North and South American women physicians, helping women

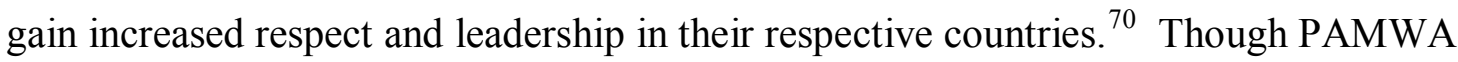
was a success, Brodie explained that there were some problems in their organization as

\footnotetext{
${ }^{67}$ Brodie, Dr. Jessie, 204.

${ }^{68}$ Our Alianza and How it Grew, 1946-1979, PAMWA Congress XVI, Sept. 1979, p.4, JLB Papers, Box 7 , "Manuscripts" folder.

${ }^{69}$ Donna Guy, "The Politics of Pan-American Cooperation: Maternalist Feminism and the Child Rights Movement, 1913-1960," in White Slavery and Mothers Alive and Dead: The Troubled Meeting of Sex, Gender, Public Health, and Progress in Latin America (Lincoln and London: University of Nebraska Press, 2000), 54-71.

${ }^{70}$ Tegualda Ponce, M.D., "Progress of the Pan American Medical Women's Alliance," JAMWA, Aug 1958, Vol. 13, No. 8, 329-332, JLB Papers, Box 7, “Journals” folder; Letter from Tegualda Ponce, 8/14/58, JLB Papers, Box 2, "1958 [2] (Correspondence, Photos, Newsclippings" folder.
} 
they continued to mature. First and foremost, was the fact that Latin American economies lacked the stability of the United States economy so there was often an "unpredictable depreciation of currency in many" of the countries. ${ }^{71}$ As a result, the funds raised from membership fees were held in the U.S. and American physicians served as treasurer. Low government salaries in Latin American countries also made it difficult for the doctoras from the Southern Hemisphere to attend congresses not held in their home countries. In order to facilitate more Latin American representation at North American conferences, PAMWA started a travel loan fund "for the use of members or of worthy graduate students who might need aid in order to take advantage of available fellowships." 72 After the second year that the fund was in place PAMWA started charging a "moderate interest" on the loans and with the interest money they maintained a "steadily growing capital."73 By 1979, this helpful fund provided "more than 150 members" travel to the congresses, "supplied funds for graduate medical education," and "helped to furnish a medical laboratory," all of which brought Brodie and other PAMWA members a sense of pride. ${ }^{74}$

Another problem that arose in PAMWA's first several years was due to racial tensions in the United States, the thorny underside of racial liberalism and early multicultural efforts in education and social work in the 1950 's. ${ }^{75}$ Originally the doctoras

\footnotetext{
${ }^{71}$ Brodie, Dr. Jessie, 213.

72 "Latin-American Colleagues Visit the United States," JAMWA Vol. 9, No. 1 (January 1954): 21, JLB Papers, Box 7, "Journals" folder.

${ }^{73}$ Brodie, Dr. Jessie, 214.

${ }^{74}$ Our Alianza and How it Grew, 1946-1979, PAMWA Congress XVI, Sept. 1979, p.5, JLB Papers, Box 7 , "Manuscripts" folder.

${ }^{75}$ See discussion in Gordon, Moral Property of Women, 233-241, 250-252; Rickie Solinger, Pregnancy and Power: A Short History of Reproductive Politics in America (New York and London: New York University Press, 2005), 137-149.
} 
tried to choose a southern city in the U.S. as the venue for congresses because of the proximity to Latin America. The thought was that if the city were closer, the travel funds would be less for the financially strapped doctoras, but there were two members from the U.S. and many delegates from Latin America who were black. ${ }^{76}$ With Jim Crow laws still in effect in the American South, the southern hotels informed PAMWA that "no black members of the delegations could be housed" with the white members. ${ }^{77}$ Brodie said that because of this "impossible situation," that is, with the belief that Jim Crow laws were repulsive and wrong, PAMWA chose to hold their congresses in western or northern U.S. cities so that all members could attend. ${ }^{78}$ It bears mentioning that Brodie, consistent with her view of the west as home to more egalitarian gender relations, held out Oregon especially as open and historically "progressive" on race. ${ }^{79}$ Like Mary Church Terrell's historic appearance at the 1904 International Conference of Women in Berlin, the post-war internationalist scene sometimes created openings for black women's voices on the world stage. In PAMWA, pioneering doctors like Dr. Dorothy Ferebee and Dr. Helen Dickens made a powerful representation for the progress of African American women in medicine. ${ }^{80}$ This solved their issue for the moment and seemed to cause minimal inconvenience for the Latin American doctors and allowed all members of PAMWA to participate fully in the congresses.

\footnotetext{
${ }^{76}$ Brodie, Dr. Jessie, 214.

${ }^{77}$ Ibid.

${ }^{78}$ Ibid.

${ }^{79}$ Ibid., 84.

${ }^{80}$ Ibid., 214-217; For discussion of Dr. Ferebee's contributions to American medicine and birth control see, Solinger, Pregnancy and Power, 142; Joanna Schoen, Choice \& Coercion: Birth Control, Sterilization, and Abortion in Public Health and Welfare (Chapel Hill and London: The University of North Carolina Press, 2005), 45-46; and Ellen S. More, Restoring the Balance: Women Physicians and the Profession of Medicine, 1850-1995 (Cambridge: Harvard University Press, 1999), 167-168.
} 
As a result of the early controversy with Dr. Mason-Hohl's birth control affiliations and the resolution made to diffuse the situation, PAMWA "avoided the inclusion of papers on birth control" for the first sixteen years of their existence "out of consideration for the fact that it was a mixed religious group." 81 Brodie respected this decision, despite her involvement with the birth control movement in Oregon. The papers she presented at PAMWA Congresses focused on pediatric conditions until it became acceptable to discuss family planning programs with the predominantly Catholic Latin American physicians in the late 1960's. She did explain that the subject was not avoided completely and as early as 1953, in New York, Brodie held a "symposium on sex education in the various countries." ${ }^{82}$ At the same conference a paper was presented by one of the Latin American doctoras concerning the prevalence and mortality rate in Chile due to septic abortions. ${ }^{83}$ According to Brodie, several papers with this focus were presented at PAMWA meetings over the next decade, and gradually "Latin American physicians in general, saw the dangerous sequelae of the mounting number of septic abortions" causing them to take the leadership of family planning in Latin America. ${ }^{84}$ This shift in Latin American views toward birth control did not gain momentum until the mid to late 1960's and Brodie's role was minimal until she joined the Pathfinder Fund as a consultant well after she had made increased contributions to the birth control movement in her own country. Indeed, the main result of her internationalism through

\footnotetext{
81 "Family Planning and Our Latin American Colleagues," JAMWA Vol. 23, No.6 (June 1968): 559, JLB Papers, Box 7, "Birth Control Articles" folder; Letter to Elton Kessel, MD, 11/21/66, p.2, JLB Papers, Box 7, "Biographical Material" folder.

${ }^{82}$ Letter to Elton Kessel, MD, 11/21/66, p.2, JLB Papers, Box 7, "Biographical Material” folder.

${ }^{83}$ Brodie, Dr. Jessie, 353-354.

84 "Family Planning and Our Latin American Colleagues," JAMWA Vol. 23, No.6 (June 1968): 559, JLB Papers, Box 7, "Birth Control Articles" folder.
} 
PAMWA was increased status and cache at home, as an international participant and contributor, rather than a mutually constructed feminist medical agenda for women of the Americas.

Brodie's involvement with PAMWA, as a founding member and as President from 1953-1956, as well as her increased role with AMWA as editor for the PanAmerican edition of JAMWA after the 1956 PAMWA Congress, gained her recognition at home and the honor of being nominated for the office of President of AMWA. In November of 1956 Brodie received a letter from Dr. Esther Pohl Lovejoy, another woman physician from Oregon who was on the board of AMWA and President of the American Women's Hospitals, nominating her for the position of President of AMWA and inquiring as to whether or not she would accept the position. ${ }^{85}$ Lovejoy believed that Brodie's affiliation with PAMWA would serve both AMWA and MWIA well as she thought women physicians around the world should band together as they were all a minority, accenting commonalities among women rather than differences structured by the larger post-war global order. Brodie's immediate response was to decline the nomination due to her medical practice and obligations in Portland, and the inability to make the "financial investment for travel," but by early 1957 when Dr. Lovejoy wrote in an attempt to nominate her again, she agreed. Dr. Lovejoy informed her that she was unable to nominate Brodie for that year, but would bring her name up as a nominee for the following term. Brodie was nominated and assumed the AMWA Presidency in 1959.

${ }^{85}$ Letter from EP Lovejoy, 11/2/56, JLB Papers, Box 5, "Brodie, J.L., President, June 1959-June 1960" folder. 
Portland was quite proud of Brodie's nomination to AMWA, printing announcements along with in depth accounts of Brodie's career in both the Oregonian and the Oregon Journal. ${ }^{86}$ In her inaugural address to AMWA, she said she felt "inadequate, humble and thankful" by the response she received in local papers about her nomination as President of AMWA. ${ }^{87}$ Brodie's humbled and gracious attitude was also reflected in her response to a PAMWA colleague's congratulatory letter which said that she was "gifted with an uncommon ability for establishing human relations" and that with those attributes she would be an asset to any national or international organization that Brodie might be involved with at that moment or in the future. ${ }^{88}$ Despite the humility with which she accepted the AMWA Presidency, Brodie was determined to "build up confidence" so that she could live up to the challenge of the post and make a lasting contribution to the organization that would be as "worthy" as those of her predecessors. ${ }^{89}$

Brodie's inaugural speech was entitled "Service Unlimited-AMWA," a phrase that reflected the path she followed in both her medical practice and in her affiliations with various organizations. She sought to emphasize AMWA as a "service organization on the local, national and international level," and highlighted the work of the American

\footnotetext{
86 "Portland Woman Wins High Medical Post," Oregon Journal, 8/26/58, JLB Papers, Box 2, “1958 [1] (Correspondence, Photos, Newsclippings" folder; "Gavel Due Dr. Brodie: Medical Group Picks Portlander," Oregonian, 8/10/58, http://infoweb.newsbank.com.proxy.lib.pdx.edu/iwsearch/we/HistArchive/?p_product=EANX\&p_theme=ahnp\&p_nbid=G5DP4CVJMTMyOTY5NzAyMy42 NjExMzI6MToxMzoxMzEuMjUyLjk2LjI4\&p_action=doc\&s_lastnonissuequeryname=3\&d_viewref=sear ch\&p_queryname=3\&p_docnum=128\&p_docref=v2:11A73E5827618330@EANX12C30FAD5DEDDC61@2436426-12BC60A5E0884C62@81-12C3137721419C60

87 "Service Unlimited-AMWA," 6/6/59, Inaugural Address, p.1, JLB Papers, Box 7, "Manuscripts" folder.

${ }^{88}$ Letter from Tegualda Ponce, 8/14/58, JLB Papers, Box 2, "1958 [2] (Correspondence, Photos, Newsclippings" folder; Letter to Tegualda Ponce, 9/26/58 , JLB Papers, Box 2, "1958 [2] (Correspondence, Photos, Newsclippings" folder.

89 "Service Unlimited-AMWA," 6/6/59, Inaugural Address, p.1, JLB Papers, Box 7, "Manuscripts" folder.
} 
Women's Hospitals (AWH) and MWIA, internationally; student loan funding, internships, and support for young women physicians with families, nationally; and contributions at the local branch level for building a community of women physicians that could learn from and support each other. ${ }^{90}$ Brodie intimated that this notion of service was probably not foreign to these women physicians as the "profession of medicine itself" was built on a "tradition of service." 91 With this tradition in place she explained that on an international scale the "foreign mission field" was a logical choice for women physicians because "the ethics and beliefs of spiritual faith often have found the most direct route into the lives of underprivileged peoples through the service and example of a dedicated physician." ${ }^{\text {92 }}$ Brodie illustrated the notion of "international goodwill" by explaining how the AWH was able to quickly donate funds to the Austrian Medical Women's Association in an effort to help Hungarian refugees that escaped their country "after their heroic revolt against Communist aggression." ${ }^{.93}$ She further explained that this rapid response to a Cold War crisis was a "practical way to play our part as 'understanding' rather than 'ugly' Americans." "94 This statement is a direct reflection of the Cold War politics that shaped the U.S. foreign policy of the 1950's and 1960's and dictated how international organizations operated during this period. These "Medical Diplomats," as Brodie refers to them, were essential to the strengthening of international relationships. In fact, Brodie could have been defined as one of these "Medical

\footnotetext{
${ }^{90}$ Ibid.

${ }^{91}$ Ibid., 4.

${ }^{92}$ Ibid., 4.

${ }^{93}$ Ibid., 7.

${ }^{94}$ Ibid., 7.
} 
Diplomats" herself because of the work she had participated in with PAMWA, which had led her to the AMWA Presidency.

At the local and national levels Brodie iterated that she wanted to focus on, and continue to build the image of "physician as adviser" through student/physician mentorships, the AMWA student loan fund, and the development of programs to support part-time physicians with young families. The student/physician mentorships through the local branches helped young women physicians transition into their role as a doctor and often gave them access to medical information pertinent to women that was outside the regular curriculum, including "marriage counseling, [and] teaching of contraceptive techniques." 95 The AMWA student loan fund had "extremely generous terms of repayment" and waived interest during medical school and the internships that followed. ${ }^{96}$ This loan fund served a vital purpose for many medical students who reached a point in their education where they were unable to fund anything further.

Perhaps the most significant to Brodie, beyond the international piece, was that of creating a roster of "part-time medical jobs" for women who wanted to raise a family without "losing contact with active medical practice." $"$ "97 Brodie had long thought it was possible for women to maintain both a career and a family if they had the support and the strength, and this type of program that was offered by AMWA illustrated that many other women agreed with her stance, but they were hesitant to participate in this seemingly radical change that she was proposing for women in medicine. Brodie's views toward "equal" opportunity in medicine and the ability of women to balance a career and family

\footnotetext{
${ }^{95}$ Ibid., 9.

${ }^{96}$ Ibid., 11.

${ }^{97}$ Ibid., 12.
} 
were somewhat of an anomaly. In fact, her career itself was exceptional because she came out of an era of women physicians that believed they had to choose between a career or a family, and if they chose both "faced formidable obstacles and not a little prejudice." ${ }^{98}$ The fact that Brodie faced few challenges in her career or education could arguably be directly linked to the egalitarian values that she continually defined as specific to Oregon; values that she sought to make available to women physicians around the country through this program for young women physicians. Medicine was, and still is, a constantly evolving profession and Brodie recognized this stating that long absence from the medical field made contacts and current knowledge "almost impossible to regain." ${ }^{99}$ Modified work schedules for young women physicians in this situation would allow them to maintain professional relationships and constantly changing medical knowledge, as well as their valuable roles in their personal lives as wives and mothers. ${ }^{100}$ Brodie carried these foci from the previous AMWA President, helped further them during her presidency, and then continued to bring attention to these programs while serving as Executive Director for AMWA, from 1961-1964.

Concurrent with Brodie's national role in her AMWA nomination, presidency, and role as Executive Director, she held an important position at the local level in Portland. In 1947, shortly after the first PAMWA meeting, Brodie joined the local chapter of Soroptimists, an organization of professional women dedicated to improving

\footnotetext{
${ }^{98}$ Ellen S. More, Restoring the Balance: Women Physicians and the Profession of Medicine, 1850-1995 (Cambridge: Harvard University Press, 1999), 195.

${ }^{99}$ Service Unlimited, AMWA, 6/6/59, Inaugural Address, p.12, JLB Papers, Box 7, "Manuscripts" folder ${ }^{100}$ AMWA article in Toronto newspaper, JLB Papers, Box 9, Scrapbook, 1961-1963. Legacy Center, Drexel University College of Medicine.
} 
the lives of women and girls in their home communities and internationally. ${ }^{101}$ Locally, the Soroptimists were involved with the Oregon Council on Aging, of which Brodie was Health Chairman, collaborating to establish a senior center for elderly women. ${ }^{102}$ The success of this facility led to cooperation with the Portland Housing Administration, during Brodie's term as President from 1959-1960, to build a senior housing center in downtown Portland. ${ }^{103}$ Her involvement with this project and the Oregon Council on Aging prompted Oregon Governor Mark Hatfield to request that Brodie serve as a delegate to the first White House Conference on Aging in 1961, a position she accepted with the intent of helping find more ways to improve the health and housing situations of the elderly American population. ${ }^{104}$ She participated in preparations for a second national conference on aging in the mid-1970's and remained proud of her affiliation with this group and its accomplishments throughout the rest of her life.

In addition to the collaboration with the Council on Aging, the Soroptimists of Portland had an annual dinner benefitting the Salvation Army's White Shield home. The tradition was started by Eva Meyer, the wife of Fred Meyer, as a "Birthday Memorial Fund" because she thought that many of the Soroptimist members had "reached an age" where it was more appropriate to recognize birthdays "by a donation rather than receiving gifts." 105 When Meyer passed away in 1960, during Brodie's term as President, the name

\footnotetext{
101 “Soroptimist of Portland OR,” soroptimistpdx.org, accessed February 19, 2012, http://www.soroptimistpdx.org/index.

${ }^{102}$ Brodie, Dr. Jessie, 99.

${ }^{103}$ Inaugural Address, 6/18/59, Soroptomist Club of Portland, p.6, JLB Papers, Box 5, "Soroptomist" folder.

${ }^{104}$ Letter from Governor Hatfield, 8/11/60, Invite to be member of Council on Aging, JLB Papers, Box 8, Scrapbook, 1959-1960. Legacy Center, Drexel University College of Medicine.

${ }^{105}$ Inaugural Address, 6/18/59, Soroptomist Club of Portland, p.5, JLB Papers, Box 5, "Soroptomist" folder.
} 
of the fund was changed to the Eva C. Meyer Birthday Memorial Fund for the White Shield Home, and donations to and affiliation with this organization devoted to young, unwed mothers, continued in her honor. ${ }^{106}$ Though she did not state it directly, Brodie was sure to have approved of this affiliation with her medical practice focus on adolescent gynecology as well as her previous desire to open a birth control clinic in Portland that would serve the underprivileged population that did not have easy access to these services.

Brodie was honored in 1962, with several other Soroptimists from around the country, and two from Oregon specifically, by the Soroptimist Federation of the Americas, at their biennial convention in San Francisco, with their "Woman of Distinction” citation. Maurine Neuberger was honored for her work as a U.S. Senator, her involvement with NATO and the Special Committee on Aging, and President Kennedy's Special Commission on the Status of Women. ${ }^{107}$ In attendance and honored along with Brodie was Gloria Chandler, director of public service and education for KGW, part of Pioneer Broadcasting Co, for her contributions to the local Soroptimist Club and Portland community. ${ }^{108}$ Brodie was recognized for her work as a physician, her involvement with AMWA and AWH, and providing "medical relief aid to Latin America" through her long affiliation with PAMWA. ${ }^{109}$ The media and the Soroptimist Federation characterized Brodie's role as a medical leader, both nationally and internationally, and honored her for her "distinguished leadership and eminence in public

\footnotetext{
${ }^{106}$ Ibid.

${ }^{107}$ Soroptimist Federation of America, Distinguished Leadership and Eminence in Public Life, July 1962, JLB Papers, Box 9, Scrapbook, 1961-1963. Legacy Center, Drexel University College of Medicine.

${ }^{108} \mathrm{Ibid}$.

${ }^{109}$ Ibid.
} 
life."110 In a historical period where most women were valued for their accomplishments within their homes, Brodie was a respected public leader in local, national, and international medicine.

Building on the increasing respectability of Brodie's medical leadership, both locally and nationally, her role as the leader of AMWA had led to her increased involvement in MWIA. After her Presidencies with AMWA and the Soroptimists of Portland, she toured Europe in 1960 and then Asia and the Middle East in1963, where she visited local CARE-Medico programs as a board member, as well as Planned Parenthood facilities where she observed family planning programs in several countries. ${ }^{111}$ The purpose of the observations for both CARE-Medico and Planned Parenthood was for Brodie to assess their progress in these various countries and report both successes and failures of the programs in each locale.

In Taiwan Brodie and her traveling companions met a Chinese couple who had studied obstetrics in the United States and had a small room above their medical office that was specifically for delivering babies. Brodie described the setting as "primitive" but the setting was due to the fact that the young physicians went to the U.S. for training and as a result were unable to get a government position upon their return. ${ }^{112}$ This notion of "primitive" stemmed from a "Westerncentric perspective from which notions of hygiene and sanitation were constructed and taught," with the U.S. view that their

${ }^{110}$ Ibid.

${ }^{111}$ Brodie, Dr. Jessie, 282-313.

${ }^{112}$ Ibid., 276-277. 
practices were superior to others around the world. ${ }^{113}$ The Taiwanese doctor's bought into this notion, as they viewed their U.S. medical education as superior to their national colleagues, evidenced by their explanation that "the good government jobs" were filled by doctors who were locally trained and "very jealous" that they were trained in American medical schools. ${ }^{114}$ Despite their jealousy, local physicians still got the coveted government jobs, and the U.S. trained doctors found that the education and skills they had acquired in America were useless in their field in Taiwan because they were unable to use anesthesia, epidural or otherwise, in their obstetrical practice. ${ }^{115}$ Brodie and her companions were concerned about the situation these physicians were forced to practice in because of their foreign medical training and left them "with regret" but determined that any counseling as to international education should take into consideration both the needs of the country to which the doctor would return and the specialty of the hospital in the host country. ${ }^{116}$

Brodie took this information to heart, illustrated by the fact that she viewed the clinic situations in each of the other countries that she visited on this trip in accordance with the needs of the surrounding areas and not necessarily entirely from what a Western physician believed should be the priority. In other words, Brodie made an attempt to step away from the "Westerncentric perspective" during this trip and assess the programs in Taiwan and elsewhere with consideration to the specific needs of local populations and not necessarily what Western physicians would see as a priority in their own countries.

\footnotetext{
113 Choy, Catherine Ceniza, Empire of Care: Nursing and Migration in Filipino American History, (Durham and London: Duke University Press, 2003), 27.

${ }_{114}^{114}$ Brodie, Dr. Jessie, 276.

${ }^{115} \mathrm{Ibid}$.

${ }^{116}$ Ibid., 277.
} 
In Hong Kong, Brodie had the opportunity to visit a "very up-to-date Planned Parenthood Clinic."117 The clinic had four full-time physicians, three part-time social workers, and nine nurses, and served approximately two thousand patients per week, in thirty-three clinics in Hong Kong and the surrounding areas. ${ }^{118}$ Outside of Hong Kong, in the less populated bordering districts, the economy was based in farming so larger families were necessary for labor, but many families could not "raise more than six children from eleven or twelve live births." ${ }^{119}$ Community groups in the areas made a concerted attempt to convene the residents in their districts for educational purposes, giving them information on sanitation and family planning. As a result, Hong Kong and its outlying areas saw a "steadily decreasing" birth rate until 1962 when there was an influx of pregnant women from "Red China" coming across the border to deliver their babies and escape an early version of China's one-child policy. ${ }^{120}$ Even with this increase, Brodie believed that the program in Hong Kong was impressive and quite effective. Brodie did not believe in forced abortion or coerced sterilization as means of contraception, so her support of this influx was positive as it provided an element of choice for pregnant women that they did not have in communist China, but the stance of the organizations that she was surveying for is not clear.

After the MWIA Conference in Manila, Brodie and her husband, along with Dr. Dodge, embarked on an Asian tour as representatives of CARE-Medico, a relief agency

\footnotetext{
${ }^{117}$ Ibid., 278.

${ }^{118}$ Ibid., 278.

${ }^{119}$ Ibid., 278.

${ }^{120}$ Ibid., 278.
} 
for war-torn countries. ${ }^{121}$ Their first stop on this tour was Kuala Lumpur where they met with the Malaysian National Director of Health, who showed them the local medical facilities. Brodie explained that the Federated Malay States did not have a medical school at this point and suffered from a shortage of doctor's in the region. The National Director informed the group that in addition to the building of a medical school, the country had a five-year plan to establish "health centers in 28 areas of the Federation," with one of these health centers already completed, including a hospital and an "outpatient midwifery service." 122

One hundred miles from Kuala Lumpur, Brodie visited Kuala Lipis and the CARE-Medico facilities established in that area. Their "immaculately clean" hospital was staffed by CARE-Medico and Peace Corps members and treated patients for a multitude of issues, including tuberculosis, malnutrition, muscular dystrophy, and even performed Caesarean sections for women with complicated pregnancies. ${ }^{123}$ Brodie commented that the "dedicated young people" who staffed these facilities were "performing a fine and much-needed service" and that their observations would allow them to bring back an "excellent report" of the conditions to the CARE Board. ${ }^{124}$ The goals of CARE in this particular area represented a kind of medical colonialism in that they employed American and British physicians that acted as preceptors for Malaysian medical interns and residents. Similar to nursing programs in the Philippines in the early

\footnotetext{
${ }^{121}$ CARE is a program started after World War II to provide relief to families in war torn countries throughout Europe. Brodie was involved with this group as it expanded to meet the needs of poverty stricken regions in Asia and the Middle East. The programs she observed varied by country, some focused on healthcare, especially of women and children, and some focused on education, though all were designed to empower women and improve conditions of poverty in these regions.

${ }^{122}$ Brodie, Dr. Jessie, 282.

${ }^{123}$ Ibid., 284.

${ }^{124}$ Ibid., 284.
} 
1900's, these CARE programs put an emphasis on the sanitary conditions of American medicine and tried to implement these practices under the premise of improving the "poor health" of Third World populations, resulting in a sort of "humane imperialism."125

From Malaysia, Brodie and her traveling partners made their way to Thailand where they met up with Dr. Pierra Vejjabul, Thailand's first woman physician, who had also been in attendance at the MWIA meeting in Manila. ${ }^{126}$ Dr. Vejjabul was a relative of the royal family and had run away to Paris in the 1920's in order to study medicine, returning to Thailand "to blaze the trail for medical education of other Thai women." 127 She sought employment upon her return and was appointed "head of the Department of Venereal Disease," a position that the Ministry of Health had given her in an attempt to intimidate and discourage her practicing medicine. ${ }^{128}$ Instead, Vejjabul was inspired to "institute a successful campaign against prostitution" that eventually led the government to outlaw the practice. ${ }^{129}$ The night that the law went into effect "several hundred prostitutes were dumped in her front yard" prompting Vejjabul to establish an "intensive rehabilitation program." ${ }^{130}$ Brodie visited two facilities for these women, one a prison and the other similar to a halfway house, where former prostitutes were "being medically treated, vocationally rehabilitated, and instructed in sex hygiene and child care."131

Many of the former prostitutes had children and Vejjabul, "disturbed" over what might become of them, began adopting these children, housing them in a "rambling old

\footnotetext{
${ }^{125}$ See discussion of medical colonialism in Choy, Empire of Care, 20-28.

${ }^{126}$ Brodie, Dr. Jessie, 285.

${ }^{127}$ Ibid.

${ }^{128}$ Ibid.

${ }^{129}$ Ibid.

${ }^{130}$ Ibid., 285-286.

${ }^{131}$ Ibid., 286.
} 
house on extensive grounds." ${ }^{132}$ When Brodie was there she noted that Vejjabul had at that point adopted nearly six hundred children, with sixty-five living with her at the time, many of whom were later either "readopted by Thai families, or by their own mother if Dr. Vejjabul had been able to rehabilitate them and instruct them" on how to be a "good" mother. ${ }^{133}$ Vejjabul was not married and her royal family connections had "objected to sharing the family name [Piem] with the children of prostitutes" so they had created the name Vejjabul, or "Great Woman Doctor." ${ }^{\text {"134 }}$ Brodie thought what Vejjabul was doing for her country was honorable and a great service to the country of Thailand, as did the Women's Division of Albert Einstein College of Medicine of Yeshiva University in New York. They honored Vejjabul's accomplishments in her home country with an Achievement Award in April of 1963, specifying her "contribution in medicine to her countrymen and to humanity at large" with a direct link to her influence in the Department of Venereal Disease in outlawing prostitution in Thailand. ${ }^{135}$

After an "exhausting" trip through Cambodia, Brodie and Dodge made their way to Karachi, Pakistan where they met back up with Brodie's husband Walter, and had the opportunity to visit the local Planned Parenthood affiliate. Brodie explained that the program in Pakistan was "unusually comprehensive" focusing on "education in healthy sex attitudes and marriage happiness, as well as providing medical clinics for contraceptive advice." ${ }^{136}$ She observed that they had a multitude of materials at their disposal including "illustrated charts and cartoon pictures" that aided their educational

\footnotetext{
${ }^{132}$ Ibid., 287.

${ }^{133}$ Ibid., 287.

${ }^{134}$ Ibid., 287.

${ }^{135}$ Jessie Laird Brodie, M.D.,"AMWA Presents...," JAMWA, Vol. 18, No. 8 (August 1963): 649-650.

${ }^{136}$ Brodie, Dr. Jessie, 294.
} 
venture. ${ }^{137}$ Intending to enter Afghanistan to survey their CARE-Medico facilities, the Brodie's and Dodge were stopped at the border and informed that they would have to enter the country by way of India because the two countries were at war, so they deferred their tour until after they visited India.

In New Delhi, India, the elite social connections that Brodie and Dodge had made through fellow MWIA member Dr. Kay Pasricha offered the group numerous cultural activities and allowed them to observe the conditions of women physicians and maternity hospitals in the region. Access to these medical facilities was helped by Dr. Pasricha's connections to both Indira Gandhi and the American Ambassador, John Kenneth Galbraith, leaving few obstacles for the American physicians in their visits to local hospitals. One of the hospitals they visited had a "very active program in planned parenthood" and was staffed by several women doctors. ${ }^{138}$ Brodie noted that the physicians in residence at the Victorian Maternity Hospital were all women, and the clinic that was affiliated with the hospital allowed them to gain "abundant experience" in the field of obstetrics and gynecology. ${ }^{139}$ She also observed the "primitive condition" of the maternity wing at a charity hospital they visited and stated that it "disturbed even those of us who had memories of the U.S. maternity hospitals of fifty years before."140 While speaking with some of the women physicians they came in contact with, Brodie and her group discovered the concern among India's women doctor's that it was difficult with their cultural custom of "early arranged marriages" to complete internships

${ }^{137}$ Ibid.

${ }^{138}$ Ibid., 299.

${ }^{139}$ Ibid., 300.

${ }^{140}$ Ibid., 302. 
and carry on a medical career after marriage, though the "proportion" of women who were able to had increased, especially urban areas of the country. ${ }^{141}$ Though they had seen an increase, some of the physicians relayed that their "greatest need" was for "parttime medical jobs while the children are young," a problem that Brodie could identify with as she had been promoting programs like this at home in her role as president and then executive director of AMWA. ${ }^{142}$ Brodie and her companions thought that the situation for women physicians in India was improving steadily, even though their role in that country was not to assess and report medical conditions. They were honored that the women doctors in that country welcomed them so heartily and shared the particular progress of women in Indian medicine.

The group left India and entered Afghanistan, a country where the conditions for women physicians were lagging compared to the situation they had just encountered. Brodie and her CARE colleagues were responsible for reporting on the CARE-Medico project in Kabul, where the team was dealing with "a variety of interesting problems" in what she described as an "isolated city." 143 Perhaps the greatest issue they faced was that there were only two practicing women physicians in the country. This was a problem because the female patient load was tremendous for these two doctors due to the fact that under Islamic law a male physician cannot perform a physical examination on a female. Brodie explained that a male physician could only treat female patient's symptoms that were "pointed out to him by the husband on a doll figure carried by the doctor." 144 When

${ }^{141}$ Ibid., 300.

${ }^{142}$ Ibid., 301.

${ }^{143}$ Ibid., 303.

${ }^{144}$ Ibid., 303. 
the women were licensed they took so many female patients away from the men in the country that the male physicians retaliated by banning the women from practicing in the hospitals. ${ }^{145}$ In an attempt to bring attention to this situation, Brodie and her CARE partners were asked by the local CARE team to have a tea at the American Embassy so that the Afghan women physicians could be photographed with the American doctor's and have it reported in the papers that the Americans thought the young women had "excellent training and ability." 146 Brodie and the other CARE-Medico board members also observed the work the team put into providing internships for Afghan doctors in the local hospitals, clinical services for the needy, and establishing a crucially needed pediatric clinic. ${ }^{147}$ Brodie stated that they left Afghanistan with a "feeling of great pride in the work of the CARE-Medico mission."

After Afghanistan, the Brodie's stopped shortly in Iran where they met up with a college friend their son, before moving on to Lebanon and Jordan to complete the required work for CARE-Medico. In Lebanon, the group visited the American University of Beirut and the hospital attached to their medical college, and discussed medical issues of women and children in the region with medical school faculty. ${ }^{149}$ Jordan offered the group a chance to see the "refugee camps" where the CARE-Medico team was operating clinics, the Children's Hospital of Jerusalem where CARE-Medico ophthalmologists removed cataracts on a daily basis due to childhood malnutrition, and

\footnotetext{
${ }^{145}$ Ibid., 303.

${ }^{146}$ Ibid., 304.

${ }^{147}$ Ibid., 304.

${ }^{148}$ Ibid., 305.

${ }^{149}$ Ibid., 310.
} 
the "outstanding orthopedic program through Orthopedics Overseas."150 Brodie commented on the "religious strife" in the region and the violence that it produced in the region and praised the CARE-Medico team for their "humanitarian effort" in such a volatile area. ${ }^{151}$ Their trip concluded in New York, after a brief visit to Turkey, where the group was able to present their reports of the successful CARE-Medico missions throughout Asia and the Middle East.

During her trip through Asia and the Middle East and near the end of her stint with AMWA, just before she returned to Portland in 1964, Brodie's focus was again increasingly focused on family planning and birth control. These issues still held Brodie's interest and were extremely important to her, but her intention when she moved back to Portland was to finally retire to her home on the Clackamas River. The founding members of the Planned Parenthood Association of Oregon (PPAO) had other plans though. In a national and international political environment that was increasingly focusing on the "population crisis" and "population control," PPAO organizers recognized this climate as conducive to the establishment of a birth control clinic. They finally brought Brodie's goal of a birth control clinic to fruition in the fall of 1963, twenty-six years after her initial attempt was denied by the Multnomah Medical Society. Now an extremely well-recognized and respected physician, locally, nationally, and internationally, Brodie had the opportunity to become the first Executive Director of PPAO, a position which she graciously accepted with a sense of honor and pride, leaving

\footnotetext{
${ }^{150}$ Ibid., 311.

${ }^{151}$ Ibid., 311.
} 
retirement by the wayside, for the time being, in pursuit of her lifelong goal of bringing birth control to Oregon. 


\section{CHAPTER 3}

“An Idea Whose Time Has Come...": Planned Parenthood in Oregon and Family Planning in Latin America, 1963-1975

When Jessie Laird Brodie and her husband Walter returned to Oregon in the fall of 1964, after five years in New York with the American Medical Women's Association (AMWA), she had every intention of enjoying her "second retirement" at their home on the Clackamas River. ${ }^{1}$ At this point in her life Brodie had experienced success in her profession as a physician and in her roles of leadership in local, national, and international social and medical organizations, and was highly respected by her community and colleagues, having received the Oregon "Woman of Accomplishment" from the local Theta Sigma Pi Alumna Chapter in 1959 and the "Woman of Distinction" honor by the National Soroptimist Federation in $1962 .^{2}$ For most people this would have been a satisfying way to end a career, but the ever ambitious Brodie, having made huge strides in her goal of helping women physicians balance their careers, marriage, and motherhood, still had one major goal that she had been unable to fulfill nearly thirty years before: a birth control clinic and family planning program for the State of Oregon. Throughout the 1940's and 1950's Brodie's focus had shifted from birth control to overall women and children's health, but by the early 1960's population control and contraception had developed into issues at the forefront of national and international sociopolitical conversations. As birth and population control rapidly gained attention,

\footnotetext{
1 "Physician Jessie Brodie Honored in Milwaukie," Oregonian, 4/1/87, Jessie Laird Brodie Papers, Box 4, “1987 [1] Biosketch" folder, Legacy Center, Drexel University College of Medicine (hereafter JLB Papers).

${ }^{2}$ Soroptimist Federation of America, Distinguished Leadership and Eminence in Public Life, July 1962, JLB Papers, Box 9, Scrapbook, 1961-1963. Legacy Center, Drexel University College of Medicine.
} 
hesitation to open family planning clinics in Oregon and other locations around the country and world retreated significantly into history, creating a less contentious environment for birth control to take a firm, yet controversial, hold in American and international culture. Brodie characterized her opinion of this transition to acceptance of family planning in the U.S. and Latin America in her statement iterating that "there is no stronger force than an idea whose time has come."3

During the latter part of the 1950's and the early 1960's the argument for population control in the United States and abroad became a major issue in political spheres and birth control organizations. Feminist historians have pointed out how a new generation of Population Control experts argued that "population growth and size [were] primarily causal, rather than primarily symptomatic, of poverty, distress, and inequality," and used this manufactured, neo-Malthusian premise in an attempt to appeal to Third World governments. ${ }^{4}$ Since the 1920 s, Sanger and her supporters worked to hook birth control into the medical establishment, largely through regulatory and eugenic rhetoric, and the finally saw success when population control was united with birth control in Planned Parenthood Federation of America (PPFA). In the post war period, efforts to promote family planning as a means to improve "the standard of living of large groups" and limit population growth found a world-wide audience, especially among eugenic leaders. ${ }^{5}$ These leaders, with their eugenic background, supported this unification, as the popularity of the eugenics movement declined in the late 1940's and through the 1950's,

\footnotetext{
3 “Family Planning and our Latin American Colleagues," JAMWA, June 1968, Vol. 23, No 6, JLB Papers, Box 7, "Credentials" folder

${ }^{4}$ Linda Gordon, The Moral Property of Women (Urbana and Chicago: University of Illinois Press, 2002), 283.

${ }^{5}$ Ibid., 280-282.
} 
and easily transitioned to the population control rhetoric of the day to continue their cause under the auspices of a modified "birth control" agenda. A key feature of this modified agenda was to make the terms of "birth control" and "population control" synonymous to the American public in order to promote their cause both domestically and internationally. The language of human rights also played a part in this shift, as it connected to market choice and anti-poverty rhetoric increasingly characteristic of postwar social policy and thought. Brodie bought into this rhetoric relatively quickly with her involvement with CARE and the Medical Women's International Association (MWIA).

Brodie's discussions of traveling through Asia and Latin America and assessing their family planning resources in the early 1960's illustrated that at first population control was a subject the international political community was willing to address, but not the United States government. In 1959 President Eisenhower stated that under his leadership the U.S. government would not have a "positive political doctrine" having to do with birth control and that the subject itself was "not a proper political or

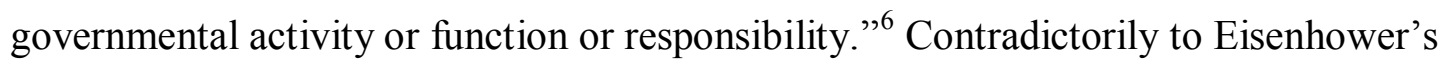
public remarks his "administration was already paying for birth control activities" in many southern states, specifically in areas with predominantly African-American populations, who many publicly considered the "precise heart of the problem" of poverty

\footnotetext{
${ }^{6}$ James Reston, "Birth Control Raises Problems Whether U.S. Likes It Or Not," Oregonian, December 13, 1959, accessed March 5, 2012, http://infoweb.newsbank.com.proxy.lib.pdx.edu/iwsearch/we/HistArchive/?p_product=EANX\&p_theme=ahnp\&p_nbid=R52N50IMMTMzMDk5ODIzMi41 NjU0ODg6MToxMzoxMzEuMjUyLjk2LjI4\&p_action=doc\&s_lastnonissuequeryname $=2 \& d$ _viewref $=$ sea rch\&p_queryname $=2 \& p \_$docnum $=13 \& \mathrm{p} \_$docref $=\mathrm{v} 2: 11 \mathrm{~A} 73 \mathrm{E} 5827618330 @$ EANX12C3531DC2231241@2436916-12BE9A055F09BE82@27-12EA0CE570BD10E8
} 
and overpopulation in the U.S. ${ }^{7}$ In other words, a racial double standard in terms of reproductive politics was both embedded and denied at the level of national political leadership, partly creating an opening for the medical establishment and state health officials around the U.S., who claimed to speak with authenticity and power about local particular needs and interests, to establish publicly funded contraceptive programs. ${ }^{8}$

PPFA addressed the issue of overpopulation at the international level by creating Planned Parenthood-World Population (PP-WP) in 1961 with the intention to "“sell' international population control to the American public." "In other words, by legitimating population control as a feature of rationally planned global economic development in the internationalist milieu of the post-war period, birth controllers in the U.S. gained momentum, media currency, and the authority of expertise and numbers that peaked for policy makers by the mid-1960's. PP-WP's main objective was to get the national government to "insert population control into U.S. foreign and domestic policy" by getting ordinary Americans to back the cause and push for it through individual political participation, mainly voting and tax increases. ${ }^{10}$ By the mid-1960's when population control officially became a part of U.S. international policy, the movement had rooted itself firmly domestically through publicity campaigns and legislation allowing birth control clinics to sprout up around the country. Part of the testing ground for market and legitimacy had been the American empire itself, namely Puerto Rico, with

\footnotetext{
${ }^{7}$ Rickie Solinger, Pregnancy and Power: A Short History of Reproductive Politics in America, (New York and London: New York University Press, 2005), 164-165.

${ }^{8}$ Solinger, Pregnancy and Power, 164.

${ }^{9}$ Gordon, Moral Property of Women, 282.

${ }^{10}$ Ibid.
} 
numerous ties to media centers like New York City, and whose population suffered considerable stigma for their reproductive behaviors and traditions in this period. ${ }^{11}$

Brodie renewed her involvement with birth control by participating at the international level with her visits to Planned Parenthood affiliates in Asia and the Middle East in 1963, but at the local level she did not officially involve herself with the movement until after she returned to Portland. There she saw her past efforts finally coming to fruition through the organization of a local Planned Parenthood. In the 1930's Brodie had attempted to establish a birth control clinic in Portland at the urging of local women's organizations but was turned down by the Multnomah Medical Society under the consensus that "the time has not yet come when such a project can be launched, and that to promote it before the time is ripe, would be to hinder its eventual accomplishment." ${ }^{\prime 2}$ By early 1963, though Brodie was not involved, the time was finally "ripe" for Portland when a steering committee, consisting of mostly middle class Portlanders who belonged to the Humanist Society, a non-religious group that believed that "reason and science were the best ways to understand the world" and "dignity and compassion should be the basis for how you act toward" others, officially organized the Planned Parenthood Association of Oregon, Inc. (PPAO). ${ }^{13}$ Their reasons for organizing were a direct response to the growing population control movement and the fear that

\footnotetext{
${ }^{11}$ Laura Briggs, Reproducing Empire: Race, Sex, Science, and U.S. Imperialism in Puerto Rico, (Berkeley, Los Angeles, London: University of California Press, 2002), 15, 122-128.

${ }^{12}$ Letter from Inez Goltra Gilbert, 12/8/36, JLB Papers, Box 6, “Contraception History” folder.

${ }^{13}$ Jeanne Radow, interview by Roberta Watts, Oregon Historical Society, March 15, 1978, Transcript, January 2008, Lines 245-247; "Minutes of the First Meeting of the Board of Directors of Planned Parenthood Association of Oregon, Inc.," Planned Parenthood of the Columbia Willamette, Board Meeting Minutes, Portland, Oregon, February 28, 1963; "What is Humanism?," American Humanism Association, Accessed March 3, 2012, http://www.americanhumanist.org/Who_We_Are/About_the_AHA/Frequently_Asked_Questions
} 
without providing access to birth control for those who needed it the most, humans were going to, as Jesalee Fosterling, a member of the committee, interpreted it, "overpopulate the world."14 In addition, Portland was on PPFA's radar because they did not have a clinic up to this point, and Dr. Alan Guttmacher, the president of the national organization, took personal interest in the efforts of this steering committee and gave them guidance in their planning. ${ }^{15}$

Financially strapped from the beginning, this organization struggled to make ends meet for the first few years. It was the drive and determination of this group of selfdescribed "do-gooders" and "beady-eyed reformers," that is, "not moneyed people" or "board types," but "professionals in the field" who were about to move from the margins to the mainstream of local society because of their organization, that allowed PPAO to succeed during those years of financial strife. ${ }^{16}$ PPFA mandated that a new affiliate wait to open until they raised at least $\$ 5000$ and had a volunteer physician available to treat patients. ${ }^{17}$ The board disagreed with PPFA and believed that it might possibly be easier for them to raise money if they had a cause that was "actually doing something visible and not just planning for it."18 These organizers, true to Oregon's "pioneer" mentality, chose to ignore the monetary requirements of PPFA, and though it was ambitious and a

\footnotetext{
${ }^{14}$ Jesalee Fosterling, interview by Roberta Watts, Oregon Historical Society, April 11, 1978, Transcript December 2007, Line 53.

${ }^{15}$ Fosterling, OHS Interview, Lines 60-62, 1978, Transcript 2007; Radow, OHS Interview, Lines 48-50, 1978, Transcript, 2008.

${ }^{16}$ Fosterling, OHS Interview, Line 217, 1978, Transcript 2007.

17 "A Meeting of the Steering Committee...," Planned Parenthood of the Columbia Willamette, Board Meeting Minutes, Portland, Oregon, January 24, 1963. This was the recommendation from Dr. Alan F. Guttmacher, the President of PPFA, for any new affiliate opening its doors. After establishment then the affiliate would have a three year provisional membership in PPFA until they were able to comply with national standards, though it was possible to comply in a shorter period of time.

${ }^{18}$ Fosterling, OHS Interview, Lines 98-99, 1978, Transcript, 2007.
} 
definite gamble, found a multitude of volunteers and opened their doors in October of 1963 with only a little over one thousand dollars in the bank. ${ }^{19}$ This illustrates a measure of autonomy and local control that has been a hallmark of women's social reform and engagement since the $19^{\text {th }}$ century which in the Portland case, proved highly successful in regard to birth control.

Portland's historically progressive political climate, with its traditions of local control, small government, and self-directed innovation, and the fact that Brodie and others had already brought a great deal of attention to birth control in the 1930's, through the campaign for a clinic and the passage of contraceptive regulation legislation, allowed PPAO to form and open with little to no opposition from the local community. Their intention in opening the clinic was not to completely disrupt Portland society, and with little funding for advertising it would have been impossible had this been their goal, but to bring a service to the community that in PPAO and PPFA's, opinion, was long overdue. $^{20}$

Jesalee Fosterling one of the founding members and second president of the board, wrote an editorial in the Portland Reporter to mark the opening and provide information about the new clinic to the Portland community. ${ }^{21}$ In the article she explained, in detail, the reasons for Planned Parenthood opening in Oregon and the services that PPAO provided. Fosterling explained that the goal of this new organization

\footnotetext{
19 "Minutes of the September Meeting of the Board of Directors of Planned Parenthood Association of Oregon, Inc.," Planned Parenthood of the Columbia Willamette, Portland, Oregon, September $19^{\text {th }}, 1963$. ${ }^{20}$ Fosterling, OHS Interview, Lines 55-58, 1978, Transcript 2007; Radow, OHS Interview, Lines 38-40, 48-50, and 611-613.

${ }^{21}$ Mrs. Charles (Jesalee) Fosterling, "Better Family Planning Offers Hope of Easing Breakdowns, Delinquency," Portland Reporter (Portland, OR), October 2, 1963.
} 
was "that we reach and teach the people who are unaware of modern methods of contraception or who have been economically unable to afford them." ${ }^{22}$ PPAO held firm to this statement from the moment their doors opened. The PPAO Board of Directors and the Medical Advisory Committee continued to emphasize that it was not the intention of this group of volunteers and activists to limit certain populations by birth control, but to ensure that women who needed it had proper access to comprehensive women's healthcare and contraception. ${ }^{23}$ This philosophy behind PPAO echoed that of Brodie in her 1930's quest for a clinic. She also had sought to find a way to provide contraceptives and family planning information to women who could not afford to or did not desire to have more children, regardless of their social standing or economic situation. In the first several years after incorporation PPAO was able to stay relatively true to their cause with "no particular public opposition," but still within the acceptable social confines of the time period, by serving mainly married women, but also single women referred by their physicians or religious leaders. ${ }^{24}$

Conservative social norms of the early 1960's, before second wave feminism and the women's movement were in full force, and the board's desire for the organization to succeed, limited the populations that the physicians were willing to serve, despite their original intention of serving single and underage women as well as those who were married. This meant distancing the organization from free sexual mores and supporting

${ }^{22}$ Ibid.

${ }^{23}$ Evidence of this exists in the PPAO Board of Directors and Medical Advisory Meeting Minutes throughout the 1960's and into the 1970's.

${ }^{24}$ Fosterling, OHS Interview, Line 118, 1978, Transcript, 2007; "High Points and Summary of Medical Advisory Committee Meetings," (Planned Parenthood of the Columbia Willamette, Portland, Oregon, April 11, 1963); "Report of the Medical Advisory Committee Meeting," Planned Parenthood of the Columbia Willamette, July 16, 1963. 
the more socially palatable notions of family planning for married couples and mothers. In the beginning the board decided that eligibility for services at PPAO would be "given to those who have born children and those who are or present themselves as married." 25 It was not a national requirement for physicians to provide birth control services to married couples until the Supreme Court passed Griswold v. Connecticut in 1965, so the guidelines that the PPAO Medical Advisory Committee devised were socially and politically appropriate and consistent with the national guidelines of PPFA. They would only cater to married women, premarital couples with "some show of good faith—within a month of wedding date," or women who were referred back to PPAO by "the medical, psychiatric, religious or other counseling agency to which they were referred by the PPAO."26 This policy statement was changed by July of 1963, before the clinic even opened its doors, to allow any women over the age of eighteen to receive help from PPAO if sought. ${ }^{27}$ Most of the board members and the Medical Advisory Committee members agreed with this change but at least one physician stepped down when PPAO made this decision to see unmarried women. ${ }^{28}$ Jeanne Radow the Chairman of the Clinic Services Committee and main volunteer registered nurse in the clinic, explained that PPAO was not "courting disaster...[or] opposition" but were still "in a sense suspect" because of the services they offered. ${ }^{29}$ When the Oregon State Public Welfare

\footnotetext{
${ }^{25}$ High Points and Summary of Medical Advisory Committee Meetings, April 11, 1963.

${ }^{26}$ Ibid.

${ }^{27}$ Report of the Medical Advisory Committee Meeting, July 16, 1963

${ }^{28}$ Ibid. Dr. Theodore Adams resigned at this point and determined that it was his obligation to let other physicians in Portland know that PPAO would allow unmarried women in their clinic. Dr. Carl Ashley was somewhat uncomfortable with this decision, but because PPAO's practices were educational came to the conclusion that his involvement with the organization would not interfere with his position as Director of the Division of Maternal and Child Health for the State of Oregon.

${ }^{29}$ Radow, OHS interview, Line 691, 1978, Transcript, 2008.
} 
Commission sanctioned birth control referrals some of the public opposition to the new clinic asserted that if women were encouraged to utilize a birth control clinic it would not only "contribute to the delinquency of unmarried mothers," but it could have the potential to create "first class prostitutes" out of some women and deter "decent men" from dating them. ${ }^{30}$

From their inception, PPAO, with several Reed College graduates on the board, served students from the college who needed access to affordable women's healthcare as well as contraceptives. Unfortunately, despite PPAO's policy, many of the physicians staffing the clinic would not provide birth control to couples who were not married. Radow recalled that early on, a Reed couple, who were not yet sexually active, went to the clinic to obtain birth control, but the staff could not disperse it because the couple was not married. ${ }^{31}$ Ironically, when they returned some time later, after they had become sexually active, the physician would provide them with the contraceptives they initially sought. Radow said:

a couple of doctors... said they had to be sexually active so you'd go out and get sexually active and come back and get your birth control method, though you might be that $20 \%$ that might get pregnant on the first two times... ${ }^{32}$

Essentially, a couple could identify themselves as married or sexually active and access birth control, but those who were trying to be responsible before becoming sexually active could not. Radow and other staff members were not particularly fond of operating

\footnotetext{
${ }^{30}$ William Swing, "Birth Control Center Gains State Approval," Oregonian (Portland, OR), September 28, 1963, accessed March 3, 2012, http://infoweb.newsbank.com.proxy.lib.pdx.edu/iwsearch/we/HistArchive/?p_product=EANX\&p_theme=ahnp\&p_nbid=V4CK4BIHMTMzMDg5NTU3MS4 xODkxMDE6MToxMzoxMzEuMjUyLjk2LjI $4 \& p$ action $=$ doc $\&$ s_lastnonissuequeryname $=3 \&$ d_viewref $=\mathrm{s}$ earch\&p_queryname=3\&p_docnum=1\&p_docref=-v2:11A73E5827618330@EANX12DA6EEF799174ED@2438301-12DA6D4F9AE89FE7@0-12DA7B86E1323EC8

${ }^{31}$ Radow, OHS interview, Lines 692-701, 1978, Transcript, 2008.

32 Ibid., Lines 714-717.
} 
the clinic in this fashion because they thought it created a system that forced deceit from people who were hoping to be honest and responsible. ${ }^{33}$

Even when couples could access birth control, PPAO did not make it an easy task. Each couple had to attend a class and interview, and then return the next day for an exam and a birth control method. ${ }^{34}$ Additionally, they were required to fall into the categories of married, 21 years or over, or 18 years with a referral from a "reputable person-a doctor, a minister, a parent, a social worker." 35 Within this multitude of requirements it was possible for unmarried women to access birth control, but "only if you were smart" because there was not "an open door for people," despite the best intentions of the PPAO Board when they were establishing policies for the clinic and organization. ${ }^{36}$ This evidenced that in some socially and politically conservative circles a hesitation toward birth control remained intact, mainly in regard to traditional marriage and familial values.

Clinics were held three times a week in their rented room in the Interfaith Counseling Center, staffed entirely by volunteers for the first two and a half years of PPAO's existence. ${ }^{37}$ These volunteers were selected for their expertise in their respective fields and their willingness to provide services to women who required care in the Portland community. In one of its first meetings, the members of the Medical Advisory Committee decided that it would be most beneficial to the cause of their agency to exclusively use Obstetrician/Gynecologists (OB/GYN) as volunteer physicians at

${ }^{33}$ Ibid., Lines 721-723.

${ }^{34}$ Ibid., Lines 713-714. Radow defined the measures that PPAO took before providing contraceptives as "Road Blocks."

${ }^{35}$ Fosterling, OHS interview, Lines 303-304, 1978, Transcript, 2007; Report of the Medical Advisory Committee Meeting, July 16, 1963; Board Meeting Minutes, June 25, 1963 and September 19, 1963.

${ }^{36}$ Radow, OHS interview, Line 727, 1978, Transcript, 2008.

${ }^{37}$ Fosterling, "Better Family Planning," Portland Reporter, 1963. 
PPAO ${ }^{38}$ Finding doctors who would take on this responsibility was not difficult for the organizers of PPAO. Fosterling estimated that about one third of the OB/GYN's in the area volunteered in the clinic on a rotating schedule, with twenty-one eagerly awaiting the opening in $1963 .{ }^{39}$ Radow credits these doctors with helping to provide a unique service at PPAO. She explained that most clinics opening in the 1960's held clinic only once per month when they first opened due to limited physician availability, but because of the "funny rotating doctors" PPAO was uniquely able to open their doors to patients on a regular weekly schedule. ${ }^{40}$

Though opening their doors with volunteers to serve the clinic proved relatively easy, supplying the clinic on a stifled budget was quite complicated in the beginning. Opening the doors with only thirty percent of the recommended startup capital did not allow PPAO to easily furnish and stock the clinic with necessary supplies. They relied nearly entirely on donations from limited fundraising and community businesses, including a donation from Brodie's husband Walter a year before Brodie began her professional involvement with PPAO. ${ }^{41}$ Radow and Marian Slade, PPAO Secretary, the only two women on the board who had been in a Planned Parenthood before the inception of PPAO, petitioned to Meier and Frank, a local department store, for funding, but instead were invited to go to their warehouse and select what items they could use in

\footnotetext{
${ }^{38}$ High Points and Summary of Medical Advisory Committee Meetings, April 11, 1963. Originally they proposed utilizing only women physicians, but decided that it would be far "too limiting and otherwise unfeasible."

${ }^{39}$ Fosterling, OHS interview, Lines 147-149, 1978, Transcript, 2007.

${ }^{40}$ Radow, OHS interview, Line 277 and Lines 279-283, 1978, Transcript, 2008. Radow used the term "funny" to describe the constantly rotating stream of physicians that participated in the weekly clinics. 41 "Minutes of the February 1964 Meeting of the Board of Directors of Planned Parenthood Association of Oregon, Inc.," Planned Parenthood of the Columbia Willamette, Board Meeting Minutes, Portland, OR, February 13, 1964. According to these minutes Dr. Walter Brodie donated two exam tables and other equipment that he no longer needed due to his retirement.
} 
the clinic. ${ }^{42}$ When they opened they had their small room stocked with an exam table, a desk, and a filing cabinet for patient records. For instrument sterilization the clinic relied on a donated pressure cooker, sometimes having to wait for instruments to cool off between patients because of the scarcity of equipment. ${ }^{43}$ Tom McCall, future Governor of Oregon but local newscaster at the time, covered the opening of the PPAO clinic in downtown Portland immediately informing the community of this new resource, dubbing it the "Pressure Cooker Clinic.",44 Brodie explained that McCall was "an enthusiastic supporter of the clinic" and "wrote glowingly of the ingenuity of the committee ['s]" use of pressure cookers for sterilization on their limited budget. ${ }^{45}$ McCall's reports highlighted the resourcefulness of these local birth control clinic "pioneers" to provide quality care to patients on extremely limited funds.

Despite the restricted budget, small workspace, and clinic advertising in newspaper editorials and the local news, it took several months for PPAO to begin seeing an influx of funding and patients. In the first month the clinic saw only twelve patients and collected less than one thousand dollars. ${ }^{46}$ With this slow accumulation of both patients and funding the PPAO Board sought to increase fundraising and educational outreach. The Fundraising and Membership Committee worked diligently to increase individual and family memberships and contributions from local businesses, foundations,

\footnotetext{
${ }^{42}$ Radow, OHS interview, Lines 258-263, 1978, Transcript, 2008. They were able to utilize sheets, boxed tea, unworn women's clothing for those patients who needed it, and a bit of furniture.

${ }^{43}$ Fosterling, OHS interview, Line 112, 1978, Transcript 2007; Radow, OHS interview, Line 306, 1978, Transcript, 2008.

${ }^{44}$ Jessie Laird Brodie, M.D., "Dr. Jessie": The Odyssey of a Woman Physician (Portland: Carolina Pacific Publishing, 1991), 341; Fosterling, OHS Interview, Lines 108-109, 1978, Transcript 2007.

${ }^{45}$ Brodie, Dr. Jessie, 341.

46 "Minutes of the October Meeting of the Board of Directors of Planned Parenthood Association of Oregon, Inc.," Planned Parenthood of the Columbia Willamette, Board Meeting Minutes, Portland, OR, October 22, 1963.
} 
and churches. Their hope was that with the doors to the clinic open, the process of obtaining substantial donations would improve. Much to their chagrin, despite increased emphasis on fundraising, the process was slow and donations inconsistent, so funds continued to hover around four thousand dollars until 1965, still one thousand less than PPFA recommended before start-up. Patient flow grew in a similarly sluggish fashion, mainly because of their downtown clinic location and limited clinic hours, taking nearly a full year to acquire two hundred regular patients. ${ }^{47}$

Though funding and patient loads were limited, the PPAO Board and their volunteers continued to fervently promote their organization throughout Portland and Oregon, and raise just enough money to stay afloat. PPAO was slowly able to build up a loyal client base and a reputation in the Portland community, due in large part to the tireless efforts of Jesalee Fosterling, one of the founding members and second president of the board, and Jeanne Radow, the Chairman of the Clinic Services Committee and main volunteer registered nurse in the clinic. These two women worked for free, as volunteers, day in and day out to keep the doors open. Radow explained, "I was running out of my bedroom, out of her kitchen, and we talked to each other a couple times a day and we were keeping this thing afloat." ${ }^{\prime 48}$ Fosterling "had tentacles into everything," reaching out to the Portland community, migrant groups, and even the state welfare office to promote the services that PPAO provided. ${ }^{49}$ While Fosterling dealt with the administrative and fundraising aspects of the organization, Radow led the Clinic Services

\footnotetext{
47 "Minutes of the September 1964 Meeting of the Board of Directors of Planned Parenthood Association of Oregon, Inc.," Planned Parenthood of the Columbia Willamette, Board Meeting Minutes, Portland, OR, September 24, 1964.

${ }^{48}$ Radow, OHS interview, Lines 296-297, 1978, Transcript, 2008.

${ }^{49}$ Ibid., Line 301.
} 
Committee, volunteered weekly in the clinic, and made connections with the Oregon Medical School Hospital in order to allow PPAO to educate post-partum patients in birth control methods before they were released from the hospital. ${ }^{50}$ These two women believed wholeheartedly in their cause, seeking to create permanent and total access to birth control for all women in Oregon, and were present at nearly every Board, Medical Advisory, and Clergy Committee meeting and were an integral part of the success of PPAO in these early years before Brodie joined the ranks.

In addition to the outreach that PPAO did in the Portland area, they received numerous requests for their services in outlying counties. Within the first year of PPAO's opening, social workers from Umatilla, Yamhill, and Washington counties had all inquired about establishing birth control services for migrant workers in their communities. ${ }^{51}$ These inquiries were coming from and fueled by the public health authorities in these counties, but once birth control services were established, their rapid growth indicated that this was a needed and relatively well received service in these communities, despite the arguable fact of race in relation to clinic demographics and locations. After discussion at both the Medical Advisory Committee and PPAO Board meetings, they decided to send Emko, a contraceptive foam, to all outlying areas. ${ }^{52}$

\footnotetext{
${ }^{50}$ Board Meeting Minutes, July 25, 1963.

51 "Minutes of the May 1964 Meeting of the Board of Directors of Planned Parenthood Association of Oregon, Inc.," Planned Parenthood of the Columbia Willamette, Board Meeting Minutes, Portland, OR, May 21, 1964; Board Meeting Minutes, January 9, 1964.

${ }^{52}$ Board Meeting Minutes, January 9, 1964. Emko was a birth control manufacturer based on the east coast. At nearly the same time that PPAO was incorporating in Oregon, Bill Baird, the youngest clinical director of EMKO, had an experience with a woman suffering from a botched abortion in an NYC hospital which started him down a road of investigation where he discovered that low-income women had extremely limited access to contraception because it was illegal for unmarried people to access birth control. Out of frustration he established a mobile clinic that catered to the women who needed birth control services the most. He became widely known for the services he provided, which eventually got him
} 
Emko was the easiest solution to providing women in rural areas with effective birth control without a formal physical exam. As quickly as they were able to provide women in difficult to reach locations with birth control, PPAO was ordered to stop by the Oregon Board of Pharmacy. PPAO immediately initiated a legal investigation into the ban and found that the 1935 Oregon law that Brodie had helped get passed prohibited the dissemination of any publicly advertised contraceptive, so because Emko had appeared in Redbook magazine it could not be widely distributed. ${ }^{53}$ In response to PPAO's inquiries the Oregon Board of Pharmacy clarified that they did not disapprove of Emko itself, but were required to abide by Oregon State laws. ${ }^{54}$ PPFA indicated that PPAO could challenge the constitutionality of the law, but the PPAO board decided that in their delicate financial situation, and the fact that they were the only birth control organization in the state, this was not the ideal time to challenge a state law. ${ }^{55}$ PPAO decided that they would attempt to reach this demographic of patient's with a product called Delfen, another contraceptive foam that also did not require a prescription and was simple to use.

fired from EMKO and then arrested in New York. Baird's challenges to anti-birth control legislation in New York ended positively in legalization. In 1966, in New Jersey, he challenged an existing "restrictive birth control statute" which led to his second arrest. The following year, 1967, Baird was arrested yet again for violating a Massachusetts Comstock law, "Crimes Against Chastity, Morality, Decency and Good Order." He challenged his arrest and this law in order to legalize birth control for all people. Baird's case went to the U.S. Supreme Court where initially it was refused, but with persistence was eventually heard. Eisenstadt v. Baird was decided in 1972 and extended the right to access contraceptives to all individuals regardless of marital status. "The Real History of Your Right to Birth Control," Pro Choice League, 20062009, Accessed August 25, 2011, http://prochoiceleague.org/history.html; "Eisenstadt v. Baird," Oyez @ IIT Chicago-Kent College of Law: U.S. Supreme Court Media, 2005-2011, Accessed August 25, 2011, http://www.oyez.org/cases/1970-1979/1971/1971_70_17.

53 "Minutes of the March 1964 Meeting of the Board of Directors of Planned Parenthood Association of Oregon, Inc.," Planned Parenthood of the Columbia Willamette, Board Meeting Minutes, Portland, OR, March 17, 1964; "Minutes of Medical Advisory Committee Meeting, PPAO Office, January 6, 1964," Planned Parenthood of the Columbia Willamette, Portland, OR, January 6, 1964; "Minutes of the February 1964 Meeting of the Board of Directors of Planned Parenthood Association of Oregon, Inc.," Planned Parenthood of the Columbia Willamette, Board Meeting Minutes, Portland, OR, February 13, 1964.

${ }_{55}^{54}$ Board Meeting Minutes, March 17, 1964.

${ }^{55}$ Ibid. 
Once this decision was made, PPAO sought to devise a plan for reaching migrant workers at regular intervals.

When PPAO's initial idea of reaching migrant groups through wide distribution of Emko, both by mail and in person, failed, they were pressed, again by county social workers, to find another viable option for treating this group of patients. Additionally, PPAO doctors needed to establish an adequate means of maintaining accurate medical records for a demographic that shifted with the seasons. Dr. James Stewart, the Public Health Director for Washington County, attended a board meeting and communicated to PPAO that the county was currently in the process of providing all migrant workers with health history cards so that they would have the ability to present them to any clinic where they sought medical services. ${ }^{56}$ Their hope was to make it easier on both patient and medical provider when migrants presented for treatment. Stewart implied that this process could be used for contraceptive distribution and women's health services as well. ${ }^{57}$

Elwood Taub, PPAO Treasurer, moved to have PPAO supply contraceptives to Oregon counties in 1964, through individual, business, and county donations, "to be given or sold to migrant workers at health centers provided for them by the counties." ${ }^{58}$ The board agreed with this proposal but would only provide methods that did not require a physical exam as was the recommendation of the PPAO Medical Advisory Board. In their mailing of contraceptive supplies, PPAO emphasized that patients using birth

\footnotetext{
${ }^{56}$ Ibid.

${ }^{57} \mathrm{Ibid}$.

${ }^{58}$ Ibid.
} 
control should come for an exam "whenever possible" to continue with contraceptives. 59 In conjunction with these recommendations, the Medical Advisory Board added that they believed that birth control pills were an "impractical method for this group [migrants]" because of "high illiteracy rates" and language barriers. ${ }^{60}$ This statement, definitely prejudicial on the surface level, did not necessarily reflect PPAO's stance toward migrant groups, but rather illustrated that they were interested in finding the most accessible and easily used method for this particular demographic, mainly because of their mobility with the changing harvest seasons. Establishing services for migrant workers in outlying counties remained the main goal of PPAO's outreach throughout 1964 and into 1965.

Brodie returned to Portland in the fall of 1964 with retirement as her plan, but with the knowledge of PPAO's existence, and birth control a cause which she had intensely petitioned for in the 1930's, she began attending the Medical Advisory Committee meetings shortly after arriving home. Her involvement with PPAO was limited to this committee until April of 1965 when she began regularly attending board meetings. Fosterling and Radow recognized that Brodie was an active member of the Oregon medical community with a great deal of "personal prestige," and believed that with her in a leadership position at PPAO she could prove to be their "connection...to respectability."61 They needed someone with credibility who could help PPAO solidify their place in the local medical community "in an organized fashion better than a group

\footnotetext{
${ }^{59}$ Minutes of Medical Advisory Committee Meeting, PPAO Office, January, 6, 1964.

${ }^{60}$ Medical Advisory Committee PPAO Minutes, May 8, 1964.

${ }^{61}$ Fosterling, OHS Interview, Line 241, 1978, Transcript 2007; Radow, OHS Interview, Line 331, 1978, Transcript 2008.
} 
of volunteers could do." ${ }^{, 2}$ As Fosterling put it, "not only was she very competent, but nobody in their right mind was gonna accuse her of being some kind of fruity freak!",63 By this glib comment, Fosterling was implying that Brodie held a certain local prominence that many of these young activists in PPAO lacked, because of her community leadership and involvement throughout her career. Brodie exemplified the respectable qualities that PPAO was looking for in a leader for their young organization, so they sought her out to fill the role of either President of the board or Executive Director, both positions that she resisted for several months before she "succumbed and decided [she] could do more as executive director" in June of $1965 .{ }^{64}$ Though initially reticent to leave retirement behind, Brodie said that she "felt honored" that Fosterling and Radow asked her to join the organization and "accepted the position willingly." 65

The issues posing challenges to and at the forefront of PPAO's agenda when Brodie was hired in 1965 were, according to her, that of the "world population explosion," "a large seasonal migrant population, adolescent pregnancies, and a poverty program in our black area. ${ }^{\prime 66}$ Additionally, the clinic was rapidly growing out of its small space in the Interfaith Counseling Center and needed to move so they could accommodate the increasing patient load. Brodie chose to address each issue individually, but her first order of business as Executive Director was to update where the clinic stood in the eyes of Oregon State law through her attorney, Clifford Zollinger. He had provided her with legal advice concerning a birth control clinic in 1933 and 1935,

\footnotetext{
${ }^{62}$ Fosterling, OHS Interview, Line 243, 1978, Transcript 2007.

${ }^{63} \mathrm{Ibid}$., Lines 244-246.

${ }^{64}$ Letter to the Zollingers, 2/5/66, JLB Papers, Box 5, "Planned Parenthood" folder.

${ }^{65}$ Brodie, Dr. Jessie, 341.

${ }^{66}$ Ibid., 341-342.
} 
and in 1965 Zollinger informed Brodie that the law for publishing "indecent" materials had been repealed and the other law, that could possibly pertain to contraceptives as “injurious to public morals," was considerably more obsolete at this juncture "because of increasing acceptance of the idea of planned parenthood."67 Essentially, in the social and political climate of 1965 Zollinger did not believe that PPAO violated any Oregon laws by operating a birth control clinic and disseminating contraceptive information.

Just before PPAO had opened in 1963 they had gotten the State Welfare department to agree to refer the patients that asked about birth control to the clinic for education on different methods of contraception and family planning. This decision helped both PPAO and the state, in that it increased patient loads and saved the government money at the time of a welfare budget shortfall. ${ }^{68}$ In July of 1965, when Brodie stepped into her role as Executive Director, the welfare commission started paying PPAO for birth control supplies and services, including pelvic exams. Fosterling stated that this development would help PPAO's "financial burden" because the clinic would receive funding for "every welfare patient that they saw," with welfare patients comprising over half of their patient load at the time. ${ }^{69}$ This decision by the State of Oregon proved significant for PPAO as they had been treating welfare patients for free during the first two years of their clinic organization.

\footnotetext{
${ }^{67}$ Letter from Zollinger, 7/6/65, JLB Papers, Box 6, “1933 Oregon Birth Control Legislation” folder. ${ }^{68}$ William Swing, "Birth Control Center Gains State Approval," Oregonian (Portland, OR), September 28, 1963, http://infoweb.newsbank.com.proxy.lib.pdx.edu/iwsearch/we/HistArchive/?p_product=EANX\&p_theme=ahnp\&p_nbid=W56C56NRMTMzMzU3ODkxOS4 2ODgxOTY6MToxMzoxMzEuMjUyLjk2LjI4\&p_action=doc\&s_lastnonissuequeryname=10\&d_viewref= search\&p_queryname=10\&p_docnum=1\&p_docref=v2:11A73E5827618330@EANX12DA6EEF799174ED@2438301-12DA6D4F9AE89FE7@0-12DA7B86E1323EC8

${ }^{69}$ Letter June 16, 1965 from Jesalee Fosterling to Dr. Janzer \& Dr. Brodie, Planned Parenthood of the Columbia Willamette, Executive Director Reports, Portland, Oregon, June 16, 1965.
} 
In response to this development Brodie publicly responded that providing these services to "medically indigent" women, or to those who were "marginal cases" making just enough to sustain their families, "was not a matter of licensing promiscuity but rather of controlling unnecessary public and private expense, as well as human heartache to children and parents alike." ${ }^{, 70}$ Here Brodie updated Sanger's earlier arguments, as well as her own from the 1930's, concerning poor women who needed resources and choices that ultimately served society's standards of efficiency, control, regulation, and economy. She believed that if these women had access and technology to do so, they would choose to limit their fertility in order to provide a life of quality, not quantity, for their children. She contended that "children by choice, not by chance" was for the "best health of the mother and the optimal welfare of the child," and that every effort should be made to provide birth control information and supplies to "all spectrums of society," but declared that "there must be freedom of choice of methods and no coercion." carry out these efforts more effectively once the welfare department extended their services to include comprehensive birth control for their recipients.

While Brodie was orienting to the position of Executive Director and attending meetings around the country, she found that this request and desire to provide birth control services to patients on welfare was not unique to Oregon. This issue was being pushed for nationally and at the Public Family Planning Clinic Conference in New York they said that "Planned Parenthood services and supplies should be available to every

\footnotetext{
${ }^{70}$ PPAO Selection of Executive Director, JLB Papers, Box 9, Scrapbook, 1965-1966. Legacy Center, Drexel University College of Medicine.

${ }^{71}$ PPAO Selection of Executive Director, JLB Papers, Box 9, Scrapbook, 1965-1966. Legacy Center, Drexel University College of Medicine; Jessie Laird Brodie, "Where Oregon is Today in Family Planning," Northwest Medicine, Vol. 66, No. 11 (November 1967): 1037.
} 
mother without regard to her financial status" and that "contraceptive advice and supplies should be part of total family care." ${ }^{72}$ She acknowledged that PPAO and Oregon were already beginning to practice these philosophies, but the organization still required more outreach, especially into the outlying counties and with the migrant population.

Providing services for migrant groups in various counties had been an ongoing issue for PPAO, even before Brodie was hired in 1965. They had seen some progress, specifically in Yamhill County where Dr. Elton Kessel had successfully established a migrant medical and contraceptive clinic in June of 1964. As he was organizing, Kessel expressed a specific need for Spanish literature to distribute to patients attending his contraceptive clinics, an idea that Brodie agreed with during her orientation and assessment of the need for contraceptive and women's healthcare services for migrant workers. $^{73}$ She suggested using Spanish films and handouts for these areas and getting the information from the offices in New York that had provided the same information to the Puerto Rican community there. ${ }^{74}$

Under Brodie PPAO continued and expanded their outreach with migrant communities throughout the state, though not without question from the community members. Brodie explained that county nurses arranged "educational meetings" for women in seasonal migrant camps and asked PPAO to present educational material and

\footnotetext{
72 "Summary of Conference on Family Planning Clinics Conference Sponsored by G.D. Searle, NYC, September, 9-10, 1965," Planned Parenthood of the Columbia Willamette, Executive Director Reports, Portland, Oregon.

73 "Minutes of the May 1964 Meeting of the Board of Directors Planned Parenthood Association or Oregon, Inc., May 21, 1964," Planned Parenthood of the Columbia Willamette, Portland, OR; "Report of the Executive Director of Planned Parenthood Association of Oregon, July 15, 1965," Planned Parenthood of the Columbia Willamette, Executive Director Reports, Portland, Oregon.

74 "Report of the Executive Director of Planned Parenthood Association of Oregon, July 15, 1965," Planned Parenthood of the Columbia Willamette, Executive Director Reports, Portland, Oregon.
} 
information about birth control. ${ }^{75}$ At these meetings Brodie said she began the proceedings in a manner that would make the women "feel at ease" by asking how many children each woman had, with most at one meeting responding no less than eight. ${ }^{76}$ When asked how many she and her PPAO colleagues had they all responded with "three" prompting one of the women to go get her daughter in law who only had one child. This action, taken by an older woman in this community, served to illustrate to the group, and to Brodie, that contraception was a desired service, but not all women had the means or ability to access it outside of their community. Brodie explained that this experience led her to come to the conclusion that "contraception cannot be retroactive" and dramatized...the fact that even in affluent America we have an educational and economic block between our middle and upper economic classes and our underprivileged and medically indigent. ${ }^{77}$

She acknowledged that class had been an issue in accessing contraception since the 1930's, but intended to change this trend through the services that PPAO provided so that even the "educationally and financially deprived" populations in Oregon could "claim their "right' to the knowledge of how to space and limit their families." migrant groups was one way of offering this "right" of birth control to a demographic of American society that fell into the "underprivileged" status of patients that Brodie and PPAO believed needed direct access to their programs.

According to Brodie the information included in PPAO's presentations to the women in seasonal migrant camps directly approached the international population

\footnotetext{
${ }^{75}$ Brodie, Dr. Jessie, 345.

${ }^{76}$ Economic, Social, and Moral Aspects of Birth Control, May 24, 1967, p.2, JLB Papers, Box 7, "Birth Control Articles" folder.

${ }^{77}$ Ibid., 3.

78 "Birth Control: How it Came to Oregon," July 10, 1966, JLB Papers, Box 7, "Birth Control Articles" folder.
} 
control debate. Her long involvement with the Pan American Women's Medical Alliance (PAMWA) had allowed Brodie a direct view of the implications that having a "population increase [that was] exceeding...economic development" had on a region and used this insight to forge a connection with the migrant communities. ${ }^{79}$ Brodie explained that in Latin America "death control," the lowering of death rates due to immunizations and effective treatments for common diseases, needed to be balanced with birth control because it was no longer necessary to "produce $10-12$ children to raise 2 or $3 .{ }^{, 80}$ Though this shift in medicine had decreased infant mortality in Latin America the birth rate had not slowed leaving women already living in poverty with more children and creating a sense of "desperation" that drove some women to "self-induced or illegal abortions often with resultant complications of infection and hemorrhage." ${ }^{" 81}$ Brodie not only wanted to see the maternal death rates from botched abortions lowered, but also sought to alleviate the "poor health" of mothers bearing children frequently, and to assist these women in reducing or eliminating the multigenerational "spiral of poverty" that these living conditions fostered. ${ }^{82}$ These views of Brodie's fit into the broader national and international context of the day, with the rhetoric espoused in both the Moynihan Report and La Vida, that there needed to be governmental action to save both the AfricanAmerican and Puerto Rican communities from the cycle of poverty by regulating their "deviant" sexuality, though she herself tended to accent rights and choice. ${ }^{83}$

\footnotetext{
${ }^{79}$ Economic, Social, and Moral Aspects of Birth Control, May 24, 1967, p.4, JLB Papers, Box 7, "Birth Control Articles" folder.

${ }^{80}$ Ibid., 5.

${ }^{81}$ Ibid, 5.

${ }^{82}$ Ibid., 6.

${ }^{83}$ Briggs, Reproducing Empire, 180-188.
} 
In the PPAO presentations that Brodie designed for the migrant "educational meetings," she "outlined briefly that when babies come too close together, both mother and child are likely to suffer" and that raising a large family had the potential for incurring great expenses. ${ }^{84}$ Once the women in the migrant camps had attended these "educational" meetings, those "who desired contraceptive services were bused to a special evening clinic" where they had the "full freedom of choice" in selecting a contraceptive method. ${ }^{85}$ Brodie iterated that the government needed to "refrain from all coercion, direct or indirect" when providing access to birth control for the medically indigent, and stated that this service fell to the responsibility of the government as it was "the right of each adult to learn all that research has developed" in order to combat the "unfreedom of ignorance" that underprivileged populations had been forced to live with for so long. ${ }^{86}$

On at least one occasion Brodie and her PPAO colleagues were confronted by a group of men who were the spouses of the women attending the meetings, who inquired as to what PPAO was "going to tell their women." ${ }^{, 87}$ Brodie maintained in her recollection that she was able to diffuse the confrontation by simply explaining the information that PPAO gave before providing contraception and that they "tried so far as possible to give the patient choice of the most effective types, depending on her physical condition. ${ }^{, 88}$ She said that the men protested, not to the contraceptive advice that she

\footnotetext{
${ }^{84}$ Brodie, Dr. Jessie, 345.

${ }^{85}$ Brodie, Dr. Jessie, 345; Economic, Social, and Moral Aspects of Birth Control, May 24, 1967, p.10, JLB Papers, Box 7, "Birth Control Articles" folder.

${ }^{86}$ Economic, Social, and Moral Aspects of Birth Control, May 24, 1967, p.10, JLB Papers, Box 7, "Birth Control Articles" folder. Underlining is original.

${ }^{87}$ Brodie, Dr. Jessie, 345.

${ }^{88}$ Ibid.
} 
was giving to their wives, but to the fact that the Spanish interpreter that PPAO planned on using was a male, and that when they found a bilingual "grandmother in the camp who had a rudimentary knowledge of anatomy" and agreed to use her as an interpreter the "questioning husbands drove off!" ${ }^{89}$ With these protesting males, from a largely patriarchal and traditionally Catholic culture, it is unlikely that this situation was as casually calmed as Brodie portrayed but it is evident that PPAO was able to create a program for women migrant workers that enabled them to easily access birth control and women's healthcare services if they so desired.

In addition to establishing birth control services for migrant groups, PPAO needed to find a new facility to house their clinic as they had long outgrown the office space at the Interfaith Counseling Center. Brodie put this at the top of her agenda shortly after she assumed the Executive Director position. In their Long Range Planning Committee meetings in the fall of 1965, they iterated that one of their goals was to provide and promote the use of family planning methods to low-income, low-education communities where there had not historically been a "good record of contraceptive practice" to promote use of family planning methods. ${ }^{90}$ By November of 1965 they had decided on a location on NE Broadway because it was affordable and significantly larger, but also, according to Jeanne Radow, the clinic director, because of its location "on the edge of the poverty area but not in it," which they thought would make their services more accessible to a wider demographic, including the "medically indigent" as well as those who could

\footnotetext{
${ }^{89}$ Ibid.

90 "Long Range Policy \& Planning Committee, First Report, September, 1965," Planned Parenthood of the Columbia Willamette, Portland, OR.
} 
afford to pay for a portion or all of their care at PPAO. ${ }^{91}$ Brodie explained that they "had chosen their location well," in regard to the accessibility it provided that the downtown location lacked, and once they were open in January of 1966, their "clinic program rapidly increased from one or two sessions weekly to several every day."92 Radow recalled that the move proved beneficial but the number of patients increased so exponentially that it was "very wild, and exciting" in the clinic. Doctors practiced what she described as "the cafeteria approach to birth control," often with patients dressing in the hallway after their exam and others waiting on the stairs to be seen by the physicians. ${ }^{93}$ Brodie attributed the rapid growth of PPAO to "gossipology" through women who had received care at the former PPAO location and communicated to the women that they knew about the family planning services that they offered. ${ }^{94}$ For Fosterling, Radow, and the rest of the PPAO Board the exponential success validated their years of hard work before Brodie joined the organization, and showed proof that hiring Brodie was an astute business decision.

By July of 1966, Brodie lamented that PPAO wished their "vision had been braver" in regard to the size of the new clinic because it was "like all adolescents" and "already pushing its arms out of the bottom of its sleeves." 95 Despite their influx of patients, PPAO was still not seeing increased numbers of minority patients, specifically

\footnotetext{
91 "Minutes of the October Meeting of the Board of Directors Planned Parenthood Association of Oregon, Inc., October 21, 1965," Planned Parenthood of the Columbia Willamette, Portland, OR; PPAO Long Range Policy \& Planning Committee, September 1965.

${ }_{92}$ Brodie, Dr. Jessie, 342.

${ }^{93}$ Radow, OHS Interview, Lines 13-22, 1978, Transcript 2008; "Public Health Birth Control Projects in Oregon Fill Need," Oregonian (Portland,OR), October 13, 1966, JLB Papers, Box 9, Scrapbook, 1965 1966. Legacy Center, Drexel University College of Medicine.

${ }^{94}$ Brodie, "Birth Control," JLB Papers, Box 7, "Birth Control Articles" folder.

${ }^{95}$ PPAO Exec. Dir. Report, July 1966, p.1, JLB Papers, Box 5, "Planned Parenthood" folder.
} 
African-Americans. Radow consistently reported very low numbers of AfricanAmerican patients, by the middle of 1965 having seen less than twenty since PPAO opened in $1963 .{ }^{96}$ As a partial solution to the problem of their burgeoning clinic, PPAO put increased effort into establishing a clinic in the Albina Community Center. This area comprised a significant "pocket of poverty" and PPAO had been trying to coordinate a clinic in the neighborhood since shortly after they opened their doors. In 1964 the board began its attempts at communication with community leaders in Albina because they thought they would be able to better reach the African-American demographic if there was a clinic that was easily accessible.

During a 1965 meeting between a PPAO Clergy Advisory member and an Albina clergyman, Chaplin Adix, the question came up as to exactly why PPAO wished to establish a clinic in their neighborhood. According to meeting minutes, he inquired as to whether or not it was to specifically limit the black population in Portland, which was a question that the PPAO clergy member could not definitively answer, highlighting PPAO's lack of awareness concerning specific racial issues. Contradictorily to Chaplin Adix, Reverend George E. Carter, who was involved in establishing the Albina Neighborhood Center, told PPAO members that the center would "love" to house a satellite clinic. ${ }^{97}$ Carter's only hesitation was that PPAO was not an agency approved by the War on Poverty Committee at that point. ${ }^{98}$ The PPAO Board reviewed and weighed

\footnotetext{
${ }^{96}$ PPAO Meeting Minutes, 1963-1965, Planned Parenthood of the Columbia Willamette, Portland, OR. There are several references to exact numbers of black patients throughout the minutes over the first two years, but after this point the racial breakdown disappears from the record.

97 “Albina Clinic Location, October 1965," in Executive Director's Reports, Planned Parenthood of the Columbia Willamette, Portland, OR.

${ }^{98}$ Ibid.
} 
this information and decided that the plan for establishing a clinic in Albina should be tabled until they could come up with a "comprehensive and understandable statement of our reasons for going into Albina." 99 It is not clear how they came to an agreement, but by February of 1966 the Albina Neighborhood Community Center, PPAO, and the Albina War on Poverty Committee all agreed on a proposal for a family planning clinic within the Albina facility, which ironically was located in an old Catholic School. ${ }^{100}$ Most likely, the community outreach to local African-American women's clubs, and the support that they offered to PPAO, probably helped them gain acceptance in a community where reluctance could have hindered PPAO's progress. ${ }^{101}$

Even though the school functioned as a neighborhood community center free of specific religious affiliation, Radow asserted that it "took a lot of surly, for us to be in a Catholic school," especially because the church still owned the building. ${ }^{102}$ The "surly" that Radow asserted represented the slight local tension that existed between PPAO and the local Catholic Church, but the fact that the clinic had the ability to operate in a Catholic owned building also illustrated the cooperation between them. When PPAO was in the process of organizing they had approached local Catholic clergy in an attempt to establish a rhythm clinic. Though the Catholic Church thought it was inappropriate to affiliate itself with PPAO, they did not specifically object to PPAO in general. After

\footnotetext{
${ }^{99}$ PPAO Board Meeting Minutes, October 21, $1965 .$.

100 "Minutes of the February Meeting of the Board of Directors Planned Parenthood Association of Oregon, Inc., February 1966," Planned Parenthood of the Columbia Willamette, Portland, OR; Radow, OHS Interview, Lines 13-22, 1978, Transcript 2008.

${ }^{101}$ Letter from Jesalee Fosterling to Mrs. Bailey, 1/6/64, Otto and Verdell Rutherford Family Collection, Special Collections, Portland State University Library; Letter on Planned Parenthood Letterhead, unknown author, 11/24/69, Otto and Verdell Rutherford Family Collection, Special Collections, Portland State University Library.

${ }^{102}$ Radow, OHS Interview, Lines 336-337, 1978, Transcript 2008.
} 
declining PPAO's offer, local Catholic physicians announced that they intended to open a rhythm clinic specifically for "Catholic parents" and manned by Catholic physicians. ${ }^{103}$ It is clear that though PPAO and the local Catholic Church did not approach birth control from the same angle, they showed each other a distinct level of professional courtesy that was not necessarily coalescent with other areas of the country where the battle between the two organizations was much more heated. ${ }^{104}$

Once the Albina clinic was approved PPAO needed to secure funding and organize staffing for their new location. Fosterling led the newly established committee responsible for application to the Office of Economic Opportunity (OEO) for a grant substantial enough to help fund the Albina clinic. Funding had been an issue for PPAO since their founding, mainly because they had such a young organization and most of the large social agencies where they could apply required that a grant recipient be incorporated for at least a year. This meant that PPAO only had private donations from individuals and businesses to rely on until they had the tax status to apply for state and federal funding, as well as grants from larger social agencies, like United Good Neighbor. Another issue that had hindered them from receiving funds from donor sources, specifically those from the federal government, was the fact that they had decided to treat unmarried women in their official policy. ${ }^{105}$ Both the board and the Medical Advisory Committee were not willing to budge on this issue so it took until July of 1966 for the

\footnotetext{
${ }^{103}$ Thomas Albright, "Catholic M.D.s Plan Rhythm Clinic," Catholic Sentinel: Baker Edition, Vol. 94, No. 40, October 3, 1963, 1.

${ }^{104}$ Tom Davis, Sacred Work: Planned Parenthood and its Clergy Alliances (New Brunswick, New Jersey, and London: Rutgers University Press, 2006), 78, 92.

${ }^{105}$ PPAO Board Meeting Minutes, October 21, 1965.
} 
OEO to approve PPAO's first substantial grant, which was specifically slated for use in establishing and staffing the Albina clinic. ${ }^{106}$

Brodie's immediate inclination toward staffing was derived directly from her previous AMWA involvement, when she suggested to the Medical Advisory Committee that they target women physicians who were either retired or temporarily out of work because of children. ${ }^{107}$ Other members of the committee suggested trying to find "Negro physicians" to cater to the "black residential area" close to where the clinic would be located, and specifically stated that "residents [physicians] not in sympathy with helping unmarried mothers need not serve" in the new clinic. ${ }^{108}$ Though they did not hire a black doctor, they were able to hire a black nurse and aide, who Brodie explained were "very helpful" in educating her and other PPAO staff "on special cultural problems."109 Brodie recalled that the nurse, Bea Gilmore, explained to her that African-American culture was "matriarchal" and that black women felt "that as they are the ones who have the children, they should have the deciding vote as to the use of contraceptives." 110 Further, Brodie recalled that Gilmore explained to her that black women were historically in control of their households, which did "nothing for the male ego," and that ministers in their communities were doing "counseling work...to help couples understand each other better" in an effort to stabilize black family life. ${ }^{111}$

\footnotetext{
106 "Minutes of the July Meeting of the Board of Directors Planned Parenthood Association of Oregon, Inc., July 21, 1966," Planned Parenthood of the Columbia Willamette, Portland, OR.

107 "Medical Advisory Committee Minutes, March 9, 1966," Planned Parenthood of the Columbia Willamette, Portland, OR.

${ }^{108}$ Ibid.

${ }^{109}$ Brodie, Dr. Jessie, 342.

${ }^{110}$ Ibid.

${ }^{111}$ Ibid., 343.
} 
In conjunction with the Albina clinic PPAO was invited to counsel unmarried women on the maternity ward at Emanuel Hospital. PPAO had been affiliated with Emanuel since mid-1964, providing educational materials to the high risk maternity program, educating their nursing students on family planning, and employing the hospital's medical residents in the clinic, but this new request augmented their already "very good connection" with the hospital. ${ }^{112}$ Initially, PPAO had looked at Emanuel for possible clinic space but the hospital did not want to be associated with them while they agreed to serve unmarried mothers, but by May of 1965 they were soliciting PPAO's expertise and service for their unmarried maternity patients. ${ }^{113}$ Radow explained that Emanuel's high risk maternity program was developed with "Kennedy money," through the Maternal and Child Health Division of the Oregon State Board of Health, and operated on two assumptions: that "mental retardation" could be prevented through better prenatal care and that if a woman had a premature baby then was pregnant again in less than eighteen months there was "a greater chance of having another premature, than...if [they] waited a little longer." ${ }^{114}$ Brodie offered further explanation of the program stating that the patients in this particular program were usually high risk because of "extreme youth, poor nutrition, [and] too many or too frequent pregnancies."115

In order to educate women on these risks and the benefits of family planning, Emanuel needed to have a birth control counseling program. According to Jeanne

\footnotetext{
${ }_{112}^{11}$ Radow, OHS Interview, Line 340, 1978, Transcript 2008.

113 "Minutes of Medical Advisory Committee Meeting, PPAO Office, January 6, 1964," Planned Parenthood of the Columbia Willamette, Portland, OR.

${ }^{114}$ Radow, OHS Interview, Lines 342-345, 1978, Transcript 2008; PPAO, Annual Report, 1967, p.2, JLB Papers, Box 5, "Brodie-Jessie, Family Planning, Planned Parenthood, Oregon" folder.

${ }_{115}$ PPAO, Annual Report, 1967, p.2, "Brodie-Jessie, Family Planning, Planned Parenthood, Oregon" folder.
} 
Radow, the Clinic Services Director, PPAO members were permitted to speak with the women who were enrolled in the high risk program, most often these were unmarried or low-income patients, but could not speak to patients with private physicians. ${ }^{116}$ She indicated that their program at Emanuel proved successful with many of the women who PPAO offered counseling to on the maternity ward actually coming to the clinic for birth control services after their hospital stay. Brodie estimated that "approximately $90 \%$ responded to this education and motivation" and that repeated home nurse visits for "drop-outs" tended to decrease the number of "repeaters, particularly among the very young unmarried mothers." ${ }^{.117}$ She and the board were proud of this success, but did note that the program was one of the "most challenging" of their interagency relationships because of the complexity and sensitivity of the program. ${ }^{118}$

Historians could argue that PPAO's involvement with the birth control counseling program at Emanuel and establishing clinics with family planning information and contraceptives, in both migrant and predominantly black communities in Oregon, came from a lingering eugenic sentiment within the state. On the surface there is truth to this argument, in that the areas where PPAO was visible were representative of high poverty and specific racial populations and substantially funded by the federal War on Poverty Committee, but statements from leaders within the organization portray a slightly different, yet carefully calculated agenda, geared toward helping low income families

\footnotetext{
${ }^{116}$ Radow, OHS Interview, Lines 345-348, 361-367. 1978, Transcript 2008.

${ }^{117}$ PPAO, Annual Report, 1967, p.2, JLB Papers, Box 5, "Brodie-Jessie, Family Planning, Planned Parenthood, Oregon" folder.

${ }^{118}$ Ibid.
} 
have "only the number of children" they wanted and could adequately provide for. ${ }^{119}$ In the immediate context of Portland, the issues of education and all-inclusive access were central to creating the spaces and legitimacy for birth control options in the health care market, especially regarding unmarried women. In regard to treating low income patients, no matter what their race or ethnicity, Brodie stated that "fertility control is the right of every family, but that there must be freedom of choice of methods and no coercion." 120 She indicated that social workers in state agencies were "directed to initiate discussion with families when they considered such advice indicated" but were only to offer a referral to an appropriate agency, leaving the decision up to the individuals. ${ }^{121}$

The aversion to any actions that were strictly eugenic in limiting reproduction is also illustrated in the board's response to an IUD inquiry from Fairview Hospital in Salem. Fairview treated mentally ill patients some of whom had weekend passes to see their families. One of the physicians at the hospital asked if PPAO would be interested in establishing an IUD clinic, specifically for the women who left on weekend passes in order to prevent pregnancy. ${ }^{122}$ The board came to the conclusion that individual physicians affiliated with PPAO were permitted to participate in an IUD clinic of this nature, but that PPAO as an organization would request that it not be involved. ${ }^{123}$ Clearly, PPAO sought to portray an anti-eugenic face to the community even though the strategic placement of their clinic locations could convincingly place their agenda within

\footnotetext{
${ }^{119}$ Brodie, "Birth Control," JLB Papers, Box 7, "Birth Control Articles” folder.

${ }^{120}$ Brodie, "Where Oregon is Today," Northwest Medicine, 1037. Emphasis in original.

121 Ibid.

122 "Minutes of the January Meeting of the Board of Directors Planned Parenthood Association of Oregon, Inc., January 20, 1966," Planned Parenthood of the Columbia Willamette, Portland, OR.

${ }^{123}$ PPAO Board Meeting Minutes, February 1966.
} 
the waning eugenic rhetoric that had defined Oregon and the country through the first half of the twentieth century.

PPAO slowly began to thrive with Brodie at the helm of the organization, mainly due to her numerous local and state medical and organizational affiliations. Within the first year of her tenure as Executive Director Brodie and the PPAO board were able to relocate the clinic to a larger location, create a strong family planning program in the migrant communities, and finally establish a clinic in the Albina neighborhood, a goal they had been aiming for since their inception. Ironically, despite all of PPAO's efforts to reach a wide and varied demographic of patients, records show that it was still white middle class paying patients who were the largest growth demographic in their case load. Under Brodie, PPAO also helped facilitate the opening of multiple county clinics that supplied their own contraceptive counseling and acted as a mentor to several counties throughout Oregon that were establishing Planned Parenthood affiliates of their own. Brodie recognized that her involvement served as benefit to PPAO during these first several years of incorporation as she had the "medical background" and "medical connections" to "call together the health officers and ask their cooperation." "124 With an increasingly improved public face, that is, from a nascent and presumably inexperienced organization to a fixture in the Portland area, and with relatively positive recognition, PPAO finally began to gain some traction in the community and throughout the state, both with their influx of patients and with their ability to get funding from different organizations. The OEO money for the Albina clinic was the first large donation that

${ }^{124}$ Dr. Jessie Laird Brodie, interview by Roberta Watts, Oregon Historical Society, February 14 and March 29, 1978, 3. 
PPAO received, but by 1969 was receiving funding from both OEO and United Good Neighbor (UGN). ${ }^{125}$ Brodie's influence during this period helped the organization expand rapidly and gave them the respect in the community and throughout the state that they had been unable to acquire prior to her appointment.

In the fall of 1966, Brodie went to a conference in San Francisco and was reacquainted with Dr. Elton Kessel who had been a health official in Yamhill County and successfully established women's healthcare services for migrant women. Kessel was the new head of the Pathfinder Fund, an organization started by Clarence Gamble in 1957 dedicated to delivering increased "access to high-quality reproductive health services" to areas around the world, and was interested in Brodie's long involvement in Latin America through PAMWA. ${ }^{126}$ Brodie followed up their San Francisco discussion with a letter that explained what PAMWA was and what they did and indicated an interest in potentially participating with Pathfinder in Latin America if the opportunity had financial incentive. ${ }^{127}$ It took Kessel nearly a year, but in the fall of 1967 he called Brodie and asked her to join Pathfinder as a "regional director" for the expansion of their program into Latin America. He explained that they needed "someone with your experience who

\footnotetext{
125 "Poverty War Aid Granted," Oregonian (Portland, OR), January 24, 1967, http://infoweb.newsbank.com.proxy.lib.pdx.edu/iwsearch/we/HistArchive/?p_product=EANX\&p_theme=ahnp\&p_nbid=M5CT5CXXMTMzMzU5MjU1OS4 4MTM2Mjk6MToxMzoxMzEuMjUyLjk2LjI4\&p_action=doc\&s_lastnonissuequeryname $=4 \& d$ _viewref $=\mathrm{s}$ earch\&p_queryname=4\&p_docnum=1\&p_docref=v2:11A73E5827618330@EANX12F419B777503E69@2439515-12F3DBF0E94E8E91@20-12F5D31877DAEB70

126 “About Us: History," Pathfinder International: A Global Leader in Reproductive Health, accessed March 17, 2012, http://www.pathfind.org/site/PageServer?pagename=About_History.

${ }^{127}$ PPAO Letterhead, Letter to Elton Kessel, MD, 11/21/66, p.2, JLB Papers, Box 7, "Biographical Material" folder.
} 
is acquainted with the doctors of Latin America" for the organizations ultimate success in the new region. ${ }^{128}$

After two years of working to secure PPAO and its services as a reputable fixture in Portland and around the state, Brodie made the decision in October of 1967 to resign from her position as Executive Director to take on this "new challenge" but with the stipulation that she desired to remain a part of PPAO in a "volunteer capacity" whenever she was available to help. ${ }^{129}$ The PPAO board was extremely supportive and accepted her resignation, expressing "appreciation for all of her involvement and regret at losing her services." ${ }^{130}$ Brodie officially stepped down in December of 1967, handing over the reins of PPAO to Jesalee Fosterling, one of the original steering committee members and active volunteer, who she thought would be "an excellent replacement" due to her continuous dedicated involvement with the local organization from its inception. ${ }^{131}$

The loss of Brodie at PPAO was publicized in the local papers and felt throughout the Planned Parenthood organization, but recognition and congratulations for her new position were extended coinciding with the regret of her departure. Alan Guttmacher, former President of PPFA and then President of the International Planned Parenthood Federation (IPPF), sent a letter to Brodie that expressed thanks for her effective

\footnotetext{
${ }^{128}$ Brodie, Dr. Jessie, 347.

${ }^{129}$ Letter of Resignation to PPAO, 10/16/67, JLB Papers, Box 9, Scrapbook, 1967-1970. Legacy Center, Drexel University College of Medicine. Brodie remained a member of the PPA Medical Advisory Committee throughout the rest of the 1960's and 1970's, attending meetings at least through 1978 and possibly longer. PPA was similar to the other organizations that she had been involved with in that she did not end her membership even when she was not able to maintain steadily active participation.

130 "Minutes of the October Meeting of the Board of Directors Planned Parenthood Association, Inc., October 19, 1967, 620 NE Broadway," Planned Parenthood of the Columbia Willamette, Portland, OR. 131 "Planned Parenthood Taps New Director," Oregonian (Portland, OR), March 4, 1968, JLB Papers, Box 9, Scrapbook, 1967-1970. Legacy Center, Drexel University College of Medicine; Letter to Jesalee Fosterling, 12/15/82, JLB Papers, Box 5, "Brodie-Jessie, Family Planning, Planned Parenthood, Oregon" folder.
} 
leadership and help during her tenure, and offering encouragement and confidence toward her new endeavor when he stated: "it is heartening to realize that what was the United States' gain will now be shared by the world," effectively highlighting the missionizing spirit typical of international relief organizations. ${ }^{132}$ A former PPAO board member and early ally in the Oregon Welfare Department, Clay Meyers, extended his commendation of Brodie's role as Executive Director and her new appointment at Pathfinder and said that the position would bring "international honor to the State of Oregon," that is, the cultural prestige associated with ambassadorship. ${ }^{133}$ With PPAO in good hands and with plenty of well-wishers Brodie set out in early 1968, once again entering the international realm, to begin her new career with the Pathfinder Fund.

Kessel sought Brodie out for Pathfinder because of her long-standing relationship with physicians throughout Latin America through her involvement with PAMWA. In the years prior to her appointment with Pathfinder, reproductive health issues were becoming more frequent at the PAMWA conferences, a circumstance that Brodie wholeheartedly supported. She explained that the movement for family planning in Latin America differed significantly from its U.S. counterpart in that "physicians and government leaders" recognized that the population in many of their countries was growing more rapidly than the economy needed to support the influx. ${ }^{134}$ The movement in the U.S. had initially organized as a grassroots movement fueled by the "wives and

\footnotetext{
${ }^{132}$ Telegrams to Radow re: Brodie at Annual Meeting, January 1968, JLB Papers, Box 9, Scrapbook, 19671970; Brodie 1991, 347.

${ }_{133}^{133}$ Ibid.

${ }^{134}$ Family Planning Programs in Latin America, 1967, p.1, JLB Papers, Box 7, “Articles and Speeches, by J.L. Brodie, M.D.” folder.
} 
mothers" who desired birth control services, mostly among the urban middle classes. ${ }^{135}$

In Latin America the birth control movement was ignited by the physician response to the substantial health problems and maternal mortality rates induced by "the mounting number of illegal and septic abortions." ${ }^{136}$ Brodie described the physicians as organizing family planning movements in Central and South America as a "weapon against their appallingly high prevalence of abortion." ${ }^{\prime 137}$ Never having supported abortion as a birth control method, she hoped to contribute to the rapidly expanding movement through her experience with Latin American medical culture and knowledge of family planning information to create a strong Pathfinder program in the countries that had the greatest need for their services.

Problems with septic abortions in Latin America had been noted by regional physicians since the late 1940 's, but it was difficult for the medical profession to gain authority to provide family planning services mainly due to the heavy Catholic influence throughout Central and South America. Brodie recalled that as late as 1962, at the PAMWA Congress in Colombia, two prominent American physicians, Dr. Mary Calderone and Dr. Adaline Pendleton Satterthwaite, were "forbidden to appear on the scientific program" because their papers "dealt with the latest medical work on contraception." ${ }^{\prime 38}$ She explained that the program for the PAMWA Congress had been

\footnotetext{
135 Ibid.

${ }^{136}$ Brodie, Dr. Jessie, 354.

${ }^{137}$ Christmas Letter, 1967, JLB Papers, Box 9, Scrapbook, 1967-1970.

${ }^{138}$ Family Planning Programs in Latin America, 1967, p. 1, JLB Papers, Box 7, “Articles and Speeches, by J.L. Brodie, M.D.” folder; Brodie, Dr. Jessie, 314. Dr. Calderone was the Medical Director of PPFA at the time of the Colombia congress and then in 1964 founded the Sexuality Information and Education Council of the United States (SIECUS) in order to provide more accurate and comprehensive information about sexuality for "both young people and adults." "History," SIECUS: Sexuality Information and Education
} 
inspected by a "committee of Catholic bishops" and due to their content had them removed from the agenda and "ordered that any printed copies of their talks...be confiscated at the port of entry." ${ }^{\prime 39}$ Fortunately for the two speakers, Brodie had smuggled in several copies of Dr. Calderone's speech and once the PAMWA planning committee appealed to the bishops, informing them that the public would not have access to this information, only the physicians that were able to treat them, they were able to hold small forums in their hotel rooms for any of the physicians who wanted contraceptive information. ${ }^{140}$ After this incident family planning papers became a fixture at PAMWA Congresses as Latin American physicians pushed to provide these services to patients in their various countries. Brodie stated that she had "never seen a comparable right-about-face as [was] apparent in the field of family planning" in Latin America. ${ }^{141}$ This was both due to the changing politics of their governments, as well as U.S. use of family planning in their foreign policy to directly address the issue of population control. $^{142}$

Brodie's "field representative" position at Pathfinder required her to travel to various countries and provide assessments of each of their family planning services to determine if Pathfinder should contribute funds to establishment of such services. The reports were shared with the U.S. State Department where they were used to determine it

Council of the United States, accessed March 18, 2012, $\mathrm{http} / /$ www.siecus.org/index.cfm?fuseaction=Page.viewPage\&pageId=493\&parentID=472;

Dr. Satterthwaite was involved with testing of oral contraceptives in Puerto Rico and then later championed the use of the IUD over the pill in Asia.

${ }_{139}$ Brodie, Dr. Jessie, 314.

${ }^{140}$ Ibid., 314-315.

${ }^{141}$ Family Planning Programs in Latin America, 1967, p.1, JLB Papers, Box 7, “Articles and Speeches, by J.L. Brodie, M.D.” folder

${ }^{142}$ Gordon, Moral Property of Women, 283. 
was necessary to pursue family planning in these various Latin American countries. The State Department's interest stemmed from the imperialistic population and birth control studies conducted in Puerto Rico. These studies served as a base for international family planning and the role that the U.S. would play in "(post)colonial poverty" and "communism" throughout the Third World in this era defined by the rhetoric of overpopulation and need for population control. ${ }^{143}$

Some of her work with family planning in the region inadvertently started in February of 1967, months before she was hired by Pathfinder, when she visited Mexico, the country where she noted the "greatest change in attitude" toward birth control services, from the 1950's to the late 1960's. ${ }^{144}$ In Mexico Brodie met Dr. Edris RiceWray who had established a family planning clinic eight years prior, after leaving the World Health Organization, because she was "tired of always working for death control" and wanted to provide birth control services so women could have "fewer but better babies."145 Rice-Wray had been the supervisor of birth control pill trials in Puerto Rico in the 1950 's, working closely with Dr. Gregory Pincus, but after growing concern about the side effects of the pill recommended that "the pill not be used further," and then shortly after stepped down from her position to work in Mexico. ${ }^{146}$

Though Rice-Wray opposed the use of the pill in some cases in Puerto Rico, she continued to work with the contraceptive in Mexico, but "treated side effects with much

\footnotetext{
${ }^{143}$ Briggs, Reproducing Empire, 110, 122-127

${ }^{144}$ Family Planning Programs in Latin America, 1967, p.1, JLB Papers, Box 7, “Articles and Speeches, by J.L. Brodie, M.D.” folder

${ }^{145}$ Brodie, Dr. Jessie, 356; "Family Planning and our Latin American Colleagues," JAMWA, June 1968, Vol. 23, No. 6 (June 1968): 559, JLB Papers, Box 7, “Credentials” folder.

${ }^{146}$ Briggs, Reproducing Empire, 139.
} 
greater seriousness" than Pincus and his staff in her continuing clinical research, and after a period of time in Mexico found that over time the "side effects and hazards" of using the pill minimized. ${ }^{147}$ She worked with missionary groups in rural areas to provide contraceptives to those in extreme poverty, but found opposition from both local midwives and the Catholic Church. ${ }^{148}$ The "granny-midwives" were opposed to RiceWray's birth control services because they made their living "producing abortions or helping at deliveries." ${ }^{149}$ In order to coerce their cooperation, Rice-Wray began paying midwives to bring patients to her clinic for contraceptives with the hope of reversing their opposition to the services she provided. Efforts to appease the Catholic Church were more difficult, but the Church did give "tacit consent to contraception in the fight against the greater sin of abortion" by overlooking the prescription of oral contraception to "postabortion" patients that presented to the clinic for care. ${ }^{150}$ A former Catholic priest also provided counseling services in local birth control clinics, promoting responsible parenthood as an extension of procreation so as to help "resolve many of the conflicts of Catholic women over the use of contraceptives and their prohibition by the Catholic Church." 151 Brodie was particularly impressed with the rapidity that Mexico changed their views toward family planning and the establishment of government birth control services for impoverished women since her experiences in the country in the 1950's.

\footnotetext{
${ }^{147}$ Briggs, Reproducing Empire, 139; Family Planning Programs in Latin America, 1967, p.4, JLB Papers, Box 7, “Articles and Speeches, by J.L. Brodie, M.D.” folder.

${ }^{148}$ Family Planning Programs in Latin America, 1967, p. 1, JLB Papers, Box 7, "Articles and Speeches, by J.L. Brodie, M.D.” folder

${ }^{149}$ Ibid., 4.

${ }^{150}$ Ibid., 2. One of the drug companies had contraceptive packaging in Mexico was labeled with the biological sign for female, a circle with a cross below, and many women asked pharmacists for the drug that the Catholic Church approved of with the "rosary and the cross."

${ }^{151}$ Brodie, Dr. Jessie, 357.
} 
Brodie's initial tour of Latin American family planning services also included El Salvador and Costa Rica, the two countries with the highest birth rates in the region in the late 1960 's. Both countries were battling poverty and population control issues but were at very different points in their progress in regard to family planning services. Brodie described El Salvador as "the most encouraging...from the family planning angle" and "probably" the country with the most need for those services. ${ }^{152}$ Without interference from the government or the Catholic Church, family planning services, including an "ambitious educational" program began taking root in El Salvador, allowing women to access birth control and serving as a training ground for other countries wanting to establish these services as well. ${ }^{153}$ When Brodie visited the first time these services were in their nascent stages, funded solely at this point by the United States Agency for International Development (USAID) with applications to IPPF and the Rockefeller Foundation, but by 1970, El Salvador was thriving and an example for other regional family planning programs.

Costa Rica's family planning program also served as a training center for other Latin American countries, and upon Brodie's evaluative visit there the existing services "impressed [her] with its well integrated program." 154 She was particularly impressed with their organization and noted the "good cooperation between the government, a strong missionary group that provided medical caravans to the distant areas, and a

\footnotetext{
${ }^{152}$ Family Planning Programs in Latin America, 1967, p.6, JLB Papers, Box 7, "Articles and Speeches, by J.L. Brodie, M.D.” folder.

${ }^{153}$ Population Planning in Latin America Today, p.6, JLB Papers, Box 7, "Birth Control Articles" folder.

${ }^{154}$ Brodie, Dr. Jessie, 359.
} 
demographic department." ${ }^{\prime 155}$ The public health clinics provided the family planning services in Costa Rica and the demographic department "had gained the cooperation of pharmacists in a countrywide distribution of oral contraceptives." ${ }^{156}$ Multiple organizations worked together throughout the country in order to provide comprehensive and consistent family planning services. Their programs included "lectures and radio skits" to appeal to all ages, as well as "weekly Caravans of Good Will to the rural areas for family planning and general healthcare." ${ }^{„ 157}$ Brodie determined that Costa Rica's established family planning program could serve as an excellent example for training purposes as Pathfinder established and organized birth control services throughout the region.

In Guatemala Brodie's survey of the family planning services found that the country needed support from Pathfinder in order to incorporate birth control into existing health programs. They had some services set up for their poverty stricken population, specifically the Guatemalan Rural Reconstruction Movement (GRRM), part of the International Institute of Rural Reconstruction (IIRR), in order to educate them on agricultural and business techniques the local people could use to organize and utilize to expand their economic base and improve the standard of living in their own communities. ${ }^{158}$ IIRR was founded in 1960 by Dr. James Yen as a response to poverty around the world, and through this Institute he sought to

${ }^{155} \mathrm{Ibid}$.

${ }^{156}$ Ibid.

${ }^{157}$ Population Planning in Latin America Today, p.11, JLB Papers, Box 7, "Birth Control Articles" folder.

158 "Report on Field Trip to Guatemala" 1968, p.1, JLB Papers, Box 7, "Guatemala" folder. 
enable communities and those who work with them to develop innovative yet practical solutions to poverty through a community-led development approach and widely share these lessons to encourage replication. ${ }^{159}$

The Institute provided funding for initial projects for three years, with the proviso that the funds be matched locally, and then if needed the country's utilizing the program could apply to have extended funding for two additional years, with the government or a local group eventually taking control of the project. ${ }^{160}$ In theory, this program sounded like a positive solution to the ongoing poverty in the country, but in reality it was difficult to organize and to fund because of the high rate of poverty in Guatemala. Dr. Yen insisted on acting as administrator in charge of the GRRM, but operated out of New York instead of having a direct, hands on approach with the community and with the people involved in the movement. This made it difficult for proper organization because he required all administrative decisions, including personnel issues, be handled by him. Brodie described Dr. Yen as "a charming gentleman" and an "idealist" but criticized his actions as an administrator for the GRRM, and worried that his influence with the group might hinder a successful family planning program in the area. ${ }^{161}$

Brodie continued her visit, seeing multiple health facilities run by the GRRM, and garnered information from the various physicians in charge of the health programs around the country. Many of the facilities not affiliated with the GRRM received funding from USAID and had some form of a family planning program, though Brodie determined that most could benefit from better supplies and support. One of the

\footnotetext{
159 "Our Mission, Vision, and Values," IIRR: International Institute of Rural Reconstruction, accessed March 20, 2012 http://www.iirr.org/index.php/aboutus/main-content/our_mission/

160 "Report on Field Trip to Guatemala" 1968, p.2, JLB Papers, Box 7, "Guatemala" folder.

${ }^{161}$ Letter to Bill, 10/4/68, p.1, JLB Papers, Box 7, "Guatemala" folder; "Report on Field Trip to Guatemala" 1968, p.2, JLB Papers, Box 7, "Guatemala" folder.
} 
programs she visited was organized by a North American man, Dr. Carroll Behrhorst, who worked with a large indigenous group where Brodie explained that he was "much better accepted than the Guatemalan doctors who tend[ed] to look down on this group."162 She further described him as an "excellent organizer and administrator" who tapped into the local population to help him with his medical practice, training women as nurses to help with IUD insertions and pelvic examinations. ${ }^{163}$ With a successful clinic, Behrhorst was attempting to get funding for a ninety bed hospital to serve the local community. He explained to Brodie that the facility would not need an extensive staff or kitchen facilities because the "indian families bring food to their sick and care for them even in the hospital." ${ }^{164}$ Brodie thought it necessary to include this important cultural note in her report to display to Pathfinder leadership how family was important to medical care within this culture and that because of this particular aspect, the hospital would not need to maintain a large medical staff as it may have elsewhere. Behrhorst's interest in Brodie's Pathfinder endeavor was due to the fact that in the new hospital he intended to run a research project focusing on birth control methods used and the "acceptance in this culture" as well as how long the women in the area would use birth control. ${ }^{165}$ Brodie approved of the proposed project and recommended to Pathfinder that they contribute some amount of funding to Behrhorst's efforts in rural Guatemala.

After visiting multiple areas around Guatemala, Brodie realized that there were enough physicians, in various regions, that were willing to take on the organization of a

\footnotetext{
162 "Report on Field Trip to Guatemala" 1968, p.7, JLB Papers, Box 7, "Guatemala" folder.

${ }^{163}$ Ibid.

${ }^{164}$ Ibid., 8.

${ }^{165}$ Ibid., 8.
} 
family planning programs through Pathfinder. She recommended granting the "entire $\$ 7000$ " to the GRRM in order to provide a salary for a full time physician and funds to organize and expand family planning services in the already existing health programs throughout the country. ${ }^{166}$

When she returned two years later, in 1970, to survey the progress of the Pathfinder grants throughout the country, Brodie found that for the most part the funds were being used effectively, but did have some reservations about some practices. Her first concern was that the "Indian Interviewers" that Behrhorst employed to speak to local women about specific birth control methods were not properly trained and did not give the women they interviewed enough information to make an informed decision about which method to choose. ${ }^{167}$ Behrhorst acknowledged this criticism of his program and was pleased to learn that Brodie was working to find an alternate individual to take control of this aspect of family planning in his local community. Brodie's other concern was with the training of Guatemalan physicians in family planning. They did not receive medical school training but after graduation could train with the Guatemalan Family Planning Association. Still, even with training she felt "uneasy about the motivation of physicians" in offering family planning services in their clinics because of the financial incentives offered by USAID for "each family planning patient they treated."168 She thought that physicians should want to contribute to the programs, not be financially coerced. Brodie asserted that there were "still problems to be removed from this

\footnotetext{
${ }^{166}$ Ibid., 5.

167 "Field Trip to Guatemala" 9/22/70, p.1, JLB Papers, Box 7, "Guatemala" folder.

${ }^{168}$ Ibid., 4.
} 
program," though overall she was impressed with the progress that had taken place since her initial visit to Guatemala in $1968 .{ }^{169}$

Brodie was satisfied with her position as a Pathfinder representative in Latin America, but she explained that she "most enjoyed working" in Haiti. ${ }^{170}$ In 1969 the U.S. State Department had mandated a survey of the status of family planning programs in the Caribbean nation and Pathfinder asked Brodie to "carry out an intensive study" over a period of four months. ${ }^{171}$ She accurately described Haiti as "the neediest country in the Western Hemisphere, sadly crippled by poverty, illiteracy, and lack of capable leadership." ${ }^{172}$ Brodie further explained, with a notably imperialistic undertone, that while she was in Haiti she "felt like the mother of a handicapped child who required extra help and understanding." 173 This notion was similar to U.S. views toward Puerto Rico that identified the population as "victimized" and in need of American protection, perpetuating a culture of imperialism within a foreign nation, while attempting to distance itself from colonialism in the media and in the eyes of other foreign nations. ${ }^{174}$

On her first visit for Pathfinder, in early 1969, she commented that she had "visited no country in which poverty [was] as evident as in Haiti" and asserted that "if any country needs a family planning program, it is this one." 175 This statement was directed toward U.S. foreign officials in her report, echoing the same colonialist agenda that was present in Puerto Rican discussions of birth control. Her survey of the country

\footnotetext{
${ }^{169}$ Ibid., 4.

${ }^{170}$ Brodie, Dr. Jessie, 363.

${ }^{171}$ Ibid.

${ }^{172}$ Ibid.

${ }^{173}$ Ibid.

${ }_{174}^{174}$ Briggs, Reproducing Empire, 2.

175 "Report of Field Trip to Haiti” 1969, p.1, JLB Papers, Box 7, "Haiti” folder.
} 
had shown that there were rudimentary efforts to provide family planning services in the country, but there was no cohesive program that could adequately reach the majority of the women who needed birth control services. Brodie iterated that "Catholicism [was] rather dormant" in Haiti, especially in regard to mission work, creating a "fertile ground for Protestantism of every kind known to man."176 The groups that were most active in Haiti's family planning belonged to the Church World Service, which consisted of over two hundred and thirty protestant groups, with the Seventh-Day Adventists, Conservative Baptists, and Episcopalians leading the push for birth control. ${ }^{177}$

Through the Church World Service Brodie found that one of the largest obstacles in getting a family planning problem off the ground in Haiti was due to the fact that "white Protestant ministers" did not understand Haitian culture in regard to marriage, and they would only provide contraception for married women. ${ }^{178}$ In Haiti marriage was expensive so common law marriages were the norm in the society, many having "six or eight children and a stable family life before accumulating the funds necessary to obtain a government license and pay the church."179 Even with these local societal norms, some of the missionaries objected to distributing birth control to unmarried couples. Brodie explained that a Baptist missionary wife was determined to have a family planning clinic, but her minister husband "objected strenuously" to treating unmarried patients. Their solution was to "build a little anteroom entrance" where they put a desk, and upon arrival

\footnotetext{
${ }^{176}$ Letter to “Extended Family,” January 1, 1970, JLB Papers, Box 7, “Haiti Corresp.” folder.

${ }^{177}$ Brodie, OHS Interview, 1978, 14.

${ }^{178}$ Brodie, Dr. Jessie, 368.

${ }^{179}$ Ibid.
} 
to the clinic the minister would marry a couple "as they passed into the clinic."180 Brodie further explained that the minister believed that this practice "was ethical as far as he was concerned." ${ }^{181}$ If they chose not to marry they were turned away, a practice neither Brodie nor the minister's wife agreed with. ${ }^{182}$ The minister's wife felt that "any sexually active woman should have this service, particularly in this culture."183 These findings led Brodie to suggest to Pathfinder that development of a family planning program in Haiti was necessary and prompted her lengthy return to the country in the fall of 1969.

During her extended stay, from September of 1969 through January of 1970, Brodie carried out the task of completing an extremely in depth survey and assessment of the logistics that would be required for establishing a successful family planning program in Haiti. In order to effectively navigate the Haitian system, Brodie found it necessary to hire an assistant to help her not only with the language, but with the customs of the culture and the government. She chose a woman physician, Nicole Garnier, who spoke French and Creole, knew the island landscape as maps were difficult to obtain, and had knowledge of government protocols. ${ }^{184}$ They travelled all around the country assessing any existing programs in family planning and maternal and child health, and the determining the need for these services which would be reported back to Pathfinder, and subsequently to the U.S. State Department, to determine how much aid should be provided to Haiti to establish family planning services.

\footnotetext{
${ }^{180}$ Brodie, OHS Interview, 1978, 16.

181 Ibid.

182 "Report of Field Trip to Haiti” 1969, p.7, JLB Papers, Box 7, "Haiti” folder.

183 Ibid.

${ }^{184}$ Letter to "Eleanor," October 18, 1969, JLB Papers, Box 7, "Haiti Corresp.” folder.
} 
As Brodie and Garnier toured Haiti's medical facilities, they observed that though many areas around the country did not have family planning programs in place, they were making efforts to improve the lives of women and children in general. In one area they were encouraging women to "raise their ground-level cooking fires up to waist high" in order to prevent children from getting frequent burns from falling into the fires. ${ }^{185}$ Another health improvement for children that Brodie observed was the tetanus vaccinations provided to pregnant women in an effort to decrease the rates of tetanus in newborns. When a child was born, midwives would use a "poultice of cow manure over the cord of the baby" which often caused an "infection of the navel and the umbilical cord" developing into tetanus, causing death. ${ }^{186}$ There was an effort to educate midwives to sterilize their scissors and to refrain from using the poultice, which helped somewhat, but the vaccination combated the situation more consistently. With the vaccination, mothers passed the immunity to their unborn babies so that they would have it "for a short time after birth" greatly decreasing the prevalence of infant tetanus deaths. ${ }^{187}$ Brodie emphasized the difficulty in organizing successful programs because of the governmental restrictions on "formal committees" under President Duvalier's ("Papa Doc") corrupt dictatorship. ${ }^{188}$ "Papa Doc" had prohibited organization of formal committees because he feared that they had the potential to become "an element that would be against him." ${ }^{189}$ Brodie and others interested in establishing reproductive health services in the country met clandestinely, often in each other's homes, calling

${ }^{185}$ Brodie, Dr. Jessie, 367.

${ }^{186}$ Brodie, OHS Interview, 1978, 17.

${ }^{187}$ Ibid.

${ }^{188}$ Brodie, Dr. Jessie, 365.

${ }^{189}$ Brodie, OHS Interview, 1978, 14. 
themselves "the non-committee committee on family planning," in an effort to devise a plan for the feasible establishment of a program. ${ }^{190}$ After operating this way for a significant portion of her visit, Brodie explained that she was "surprised and delighted" when she received permission from "Papa Doc" to "hold a one-week seminar on contraception in Port-au-Prince for the doctors stationed throughout the island and another week for the nurses and assistants."191 She coordinated with the Pan American Sanitary Bureau and Oxfam, an organization dedicated to enfranchising poor populations to ensure their livelihoods, in order to bring "French-speaking obstetricians" to Haiti for these educational meetings. ${ }^{192}$ Pathfinder sponsored "those attending the seminar," which proved to be a great success and as Brodie described, "a 'shot in the arm' for family planning education in Haiti."

The report that Brodie prepared for Pathfinder had multiple recommendations for implementing a family planning program in Haiti. She emphasized that education "at all levels," from physicians and educational institutes down to individual patients, needed to be the foundation for a family planning program in order for it to be successful. ${ }^{194}$ Her proposal included the recommendation of Dr. Garnier as the medical director and the establishment of twelve clinics throughout the country, in addition to improving the existing missionary clinics that were already offering limited family planning services. ${ }^{195}$

\footnotetext{
${ }^{190}$ Brodie, Dr. Jessie, 367.

191 Ibid.

192 Brodie, Dr. Jessie, 367; “About Us,” Oxfam International, accessed March 20, 2012 http://www.oxfam.org/en/about

${ }_{193}$ Brodie, Dr. Jessie, 367.

${ }^{194}$ First Haitian Seminar in Family Planning, September/October 1970, p.2, JLB Papers, Box 9, Scrapbook, 1967-1970. Legacy Center, Drexel University College of Medicine.

${ }^{195}$ First Haitian Seminar in Family Planning, September/October 1970, p.3, JLB Papers, Box 9, Scrapbook, 1967-1970. Legacy Center, Drexel University College of Medicine.
} 
Brodie explained that she and Garnier "meticulously suggested" to the "non-committee" that a "registered nurse be in charge of each health unit" with the medical director overseeing the entire program. ${ }^{196}$ As thorough as this study and report were, the proposal went to vote, after Brodie left Haiti, where the final decision was to "refuse the plan and grant from the Pathfinder Fund." ${ }^{197}$ Brodie was disappointed with the decision and ultimately was not clear as to reasoning behind the outcome, though she later suspected a significant governmental role, but she still believed that her efforts in Haiti had served as valuable contribution in the efforts of family planning in the country.

Brodie's experiences in Latin American and Caribbean countries with significant black populations, as well as working with the black population in the Albina clinic through PPAO, "alerted" Brodie to the "risk of prescribing the 'pill'" to women with Sickle Cell Anemia. ${ }^{198}$ She took a distinct interest in this particular disease in the 1970's, as did the U.S. government, launching a National Sickle Cell Program through the Department of Public Health in 1972, just after Congress passed the National Sickle Cell Control Act. ${ }^{199}$ Brodie wrote several papers for presentation at various conferences at a time when it was gaining increased national attention as a critical health issue specific to the African-American community. Pregnancy for patients with Sickle Cell Anemia was often not "worth the risk" with statistics showing that it accounted for "one in six maternal deaths." ${ }^{200}$ Brodie asserted that "high maternal mortality stresses the need of a

\footnotetext{
${ }^{196}$ Brodie, Dr. Jessie, 370.

${ }^{197}$ Ibid.

${ }^{198}$ Ibid., 343.

${ }^{199}$ Clarice Reid and Griffin Rodgers, "Sickle Cell Disease: Demystifying the Beginnings," in Renaissance of Sickle Cell Disease Research in the Genome Era, edited by Betty Pace (London: Imperial College Press, 2007), 2-3.

${ }^{200}$ Pathfinder, Sickle Cell Disease and the Pill, p.1, JLB Papers, Box 7, "Mexico" folder.
} 
safe and acceptable contraceptive" but that their "information to date [made] questionable the wisdom of prescribing a high estrogenic oral contraceptive."201 She explained that screening black patients was "essential to differentiate between those with sickle cell anemia and those who [were] merely carriers of the trait" but that it was a "delicate problem to advise an individual regarding genetic abnormalities that indicate limitation of reproduction," especially when the potential for abnormality was limited to a specific race of people. ${ }^{202}$ Brodie presented several papers about the disease at various venues, including PAMWA Congresses, Pathfinder Fund meetings, and conferences throughout the U.S., in an effort to bring a great deal of attention to the dangers of prescribing the birth control pill to patients with the disease, coming to the conclusion that education was the most effective way to address this particular disease. ${ }^{203}$

Brodie's interest in family planning and birth control began in the 1930's, but she had been unable to fulfill her plans of establishing birth control services in Oregon. Her participation with Planned Parenthood and the Pathfinder Fund in the 1960's and 1970's allowed her to finally achieve a life-long goal of bringing birth control to the women who needed the services the most. While working toward this goal in the 1930's her focus was on local needs, but by the time she reached the end of her career she had touched the lives of women on an international scale, by helping to provide family planning services throughout the Americas. Arguably, some of Brodie's actions could be construed as

\footnotetext{
${ }^{201}$ Pathfinder, Sickle Cell Disease and the Pill, p.1, JLB Papers, Box 7, "Mexico" folder; Brodie, Dr. Jessie, 344.

${ }^{202}$ Brodie, Dr. Jessie, 344.

${ }^{203}$ Brodie, OHS Interview, 1978, 20.
} 
eugenic or imperialistic in nature due to the national and international discourse during the time she practiced, but ultimately she wanted to see birth control brought to the masses very much in keeping with Sanger's earlier vision of empowering poor women. Her desire was not to limit specific populations per se, but to see all women, not just the affluent, with the ability to control their reproductive capacity and have children that they wanted and could provide for, just as she had been able to do in her life. The crisis of teen pregnancy in the 1950's and then the freer sexual ethos of the 1960's, combined with new policies toward population control and political openings during the War on Poverty all aided the establishment of PPAO in Oregon with delivery links to the rural migrant and African-American populations. PPAO saw long-term success because middle class women also took advantage of these services, enfolding contraception into norms of modern womanhood and sexuality, bringing a solid element of truth to Brodie's belief that birth control was finally "an idea whose time has come." 


\section{CONCLUSION}

Jessie Laird Brodie looked back at her life "with great pleasure" when she ended her autobiography in 1988. She could only recall a "few disappointments" but remarked with pride and satisfaction that her "chief concern-family planning with its educational, political, and practical suggestions - has shown a steady progress throughout the Americas." Brodie also commented that women physicians, nationally and internationally, had "received acceptance in medical schools as well as in public life."2 Indeed, statistics within the field of medicine, and among new institutions dedicated to advancing women's interest in higher education and the professions, showed that the percentages of female physicians in the United States grew throughout Brodie's life, from less than seven percent when she was in medical school, to nearly seventeen percent of the physician workforce by the time of her death in $1990 .^{3}$ She also saw her contributions to these two lifelong goals as significant to the history of birth control in Oregon widely recognized both in state and beyond. ${ }^{4}$ Her intuitiveness in her recollections of her own life prove true when looking directly at Oregon's reproductive political history, but as this thesis has shown, her contributions were far more multifaceted in their impact than Brodie projects in her autobiography and oral history. This thesis has suggested that Brodie was as good at carefully deflecting controversy as

\footnotetext{
${ }^{1}$ Jessie Laird Brodie, M.D., "Dr. Jessie”: The Odyssey of a Woman Physician (Portland: Carolina Pacific Publishing, 1991), 395.

${ }^{2}$ Brodie, Dr. Jessie, 395.

${ }^{3}$ Ellen Singer More, Restoring the Balance: Women Physicians and the Profession of Medicine, 1850-1995 (Cambridge: Harvard University Press, 1999), 5.

${ }^{4}$ Brodie, Dr. Jessie, 395.
} 
triumphing over it and has tried to elaborate how her particular style of respectability and expertise covertly enabled a significant empowerment agenda involving birth control and female sexual-choice making while stepping around some of the thorniest opponents of her lifetime: both male leaders and lawmakers, and the Catholic Church.

Brodie's life is somewhat uniquely an Oregon story, in that there were few legal barriers to women's rights or contraception when she was practicing medicine and active in the birth control movement. Because of the few and minor legal limitations derived indirectly from small-state, libertarian political traditions, Oregon's reproductive history contains many silences where in other states this history shouts with contestations. Historians of reproductive politics at the national level do not give credence to Oregon's pioneering contraceptive legislation in the 1930's because it is largely unknown in the national, and even local, historical record. Immediately following the passage of the law, Sanger's The Birth Control Review briefly mentioned the law and the positive implications it would have on birth control as other states followed Oregon's lead in regulating the manufacture and sale of contraceptives. ${ }^{5}$ This recognition remained mostly symbolic, helping to legitimize and normalize this type of this legislation, the law itself known better outside the Pacific Northwest. Overall, Brodie and her story remain as absent from the historical record as Oregon's own birth control history.

This silence is notable because into her golden years in the 1970's and 1980's Brodie was honored and publicly acknowledged with several local awards in recognition of her work as a woman physician in Oregon, as well as for her "pioneering" work in

\footnotetext{
5 "The History and Present Status of Contraception in Oregon," Draft Copy, p.2, Jessie Laird Brodie Papers, Box 6, "Oregon Contraception Law" folder, Legacy Center, Drexel University College of Medicine (hereafter JLB Papers).
} 
family planning. The Oregon Journal named Brodie as one of their "Women of Accomplishment" in 1972, where they declared that Brodie had "chopped through a forest of ignorance surrounding sex hygiene, marriage guidance and family planning." They described Brodie as having "blazed a trail" in her efforts to help not only women in Oregon, but women around the world. ${ }^{7}$ These reflections echoed the qualities of her style and approach: a "pioneer spirit" which assumed a rough equality of the sexes and an appeal to hard fact and pragmatism over ignorance and myths in the health care domain. The media's description of Brodie's life and activism is relatively accurate in regard to Oregon specifically, but elsewhere a foundation had already been laid and she was able to easily build upon it with her experience. In 1974, Brodie received an honorary doctor of laws degree from her alma mater, Reed College, for her contributions to local and international family planning. At this same ceremony Shirley Chisholm, America's first African-American Congresswoman and first African-American woman to run for President, also received an honorary doctorate after delivering the commencement speech for Reed's 1974 graduating class. ${ }^{8}$ Brodie received more local accolades when, in 1985, she was honored by Lewis and Clark College with the Aubrey R. Watzek Award for her local and international birth control efforts and encouragement of women entering the medical profession throughout her life. She received several other local awards in her

\footnotetext{
${ }^{6}$ Citation, Dr. Jessie Laird Brodie, Woman of Accomplishment, Portland 1972, p.1, JLB Papers, Box 7, "Biographical Material" folder.

${ }^{7}$ Ibid., 5.

8 "Shirley Chisholm addresses largest graduating class," Unknown publication associated w/ 1974 Honorary Doctor of Laws Degree, May 19, 1974, JLB Papers, Box 8, Scrapbook, 1974-1975. Legacy Center, Drexel University College of Medicine.
} 
later years evidencing that during her life, the local community knew the impact she had on birth control in Oregon, and credited her achievements widely.

As discussed in chapter three, when Brodie resigned from Planned Parenthood Association of Oregon (PPAO) in 1968, she moved into a volunteer and philanthropic role rather than that of an activist or political architect, while maintaining only muted authority as a medical figure within the organization. The PPAO Medical Advisory Board meeting minutes and her personal papers show that she was only intermittently involved with PPAO throughout the 1970's and attended important functions in the 1980's. Nonetheless, she remained a powerful symbol to the group. Planned Parenthood in Portland valued Brodie's contribution to their success so much that they created the Jessie Laird Brodie Award for Distinguished Community Service for the twentieth anniversary of their organization. Brodie remained a vehement supporter of birth control and Planned Parenthood until her death, but more as legitimating symbol than active collaborator with the next generation of feminists in the community.

Instead, Brodie's more active attention remained at the transnational level, as she remained active in Latin America through the Pan American Women's Medical Alliance (PAMWA) and as an emeritus member of the Pathfinder Fund into the 1980's. She was truly dedicated to promoting and supporting the careers of women physicians, both nationally and internationally, and felt rewarded by her involvement in PAMWA since its inception in 1947. Brodie was particularly pleased with the fact that after the early 1960 's it was acceptable to present information on family planning at PAMWA conferences. In 1983, at PAMWA XVIII in Mexico City, she chaired a session on family 
planning developments in Latin American countries, which was her last conference abroad. ${ }^{9}$ She valued the "extremely rich companionships" that she made through PAMWA and praised Latin American women physicians for taking the initiative in their respective countries to "improve the health and happiness of their women." 10 Through PAMWA Brodie was able to see her two major life goals, family planning and acceptance of women physicians, come to fruition and thrive. Historians can continue to question the motives behind her involvement, but in looking at her person as a whole and her local community involvement, it is relatively clear that Brodie did not necessarily seek to exploit women in Latin America, but wanted to provide opportunities for women who were less fortunate than she was in her own life. ${ }^{11}$

As a transnational, empowerment-minded female physician, with airs of latent maternalist feminist ideals permeating her involvement, Brodie's interest in internationalism reflects her coming of age in the middle decades of the $20^{\text {th }}$ century, when peace and child welfare found a strong voice on a global stage, especially in the Americas. ${ }^{12}$ Her internationalism got a boost in the heyday of the United Nations and human rights discourses of the 1950s, as PAMWA grew steadily and she increased her involvement with the Medical Women's International Association (MWIA) through her affiliation with the American Medical Women's Association (AMWA). Brodie was never one much for "protecting" young girls typical of progressive reform, rather she

\footnotetext{
${ }^{9}$ Brodie, Dr. Jessie, 383.

${ }^{10}$ Ibid., xii.

11 Ibid., xii.

${ }^{12}$ Leila Rupp, “Constructing Internationalism: The Case of Transnational Women's Organizations, 1881 1945," American Historical Review, Vol. 99, No. 5 (December 1994): 1571-1600. PAMWA is an offspring of these earlier international women's groups, but leaders recognized some of the flaws that had existed within these original international organizations and were conscious to find solutions to these mistakes as they organized in 1947, so as to avoid unnecessary conflict in the future.
} 
sought to educate and counsel them in learning how to balance a professional career with marriage and motherhood. She was neither a proponent of the hard knuckle battles over sexism of the later second wave women's movement, viewing the movement as antagonistic to and devaluing to traditional marriage and motherhood.

Jessie Laird Brodie was a well-respected woman and somewhat of a local celebrity during her life, but has been nearly forgotten as a contributor to Oregon's history. The few people who do know her name are involved with Planned Parenthood in Portland. Brodie was an iconic community figure during her life and received a significant amount of attention in the local press, but the Oregonian did not print an obituary when she passed away in July of 1990, though she did receive recognition in the Seattle Times and the Orlando Sentinel. Locally, Reed College, her alma mater, carried her obituary in their quarterly magazine, describing her as an "internationally recognized physician and early pioneer of birth-control legislation," and noted the many achievements and contributions she made toward women in medicine and family planning programs throughout her life. ${ }^{13}$

Brodie's life and experiences were essential to the growth of birth control in the state of Oregon and it is impossible to examine that history without looking at Brodie. She functioned as a voice of reason, an elite genteel professional woman, and a mother who presented birth control as a matter of hard fact and common sense not as a set of problems or confrontations over gender inequality, women's roles, or sexual autonomy per se. The legal contestations that existed elsewhere were of little issue in Oregon,

\footnotetext{
13 “Jessie Laird Brodie '20 dies,” Reed: The Quarterly Magazine of Reed College, August 1990, p.25, JLB Papers, Box 7, Envelope "Brodie-Obit" folder.
} 
making the state unique in its approach to reproductive politics, a fact that Brodie disagreed with, but did not voice, when her appeal for a birth control clinic was turned down in the 1930's. Instead, her quiet perseverance, outreach, and educational efforts over the next thirty years set a foundation that made it uncomplicated for PPAO to finally bring a birth control clinic to Oregon in 1963. In the national picture, Oregon and Brodie are left out, but this active reproductive political history, even with its comparative silences toward pivotal national upheavals, is just as important and deserves a permanent spot in the historical record. 


\section{BIBLIOGRAPHY}

\section{PRIMARY SOURCES}

Collections:

Philadelphia, PA:

Jessie Laird Brodie Papers, Legacy Center, Drexel University College of Medicine.

Portland, OR:

Oral History Collection, Oregon Historical Society

Otto and Verdell Rutherford Family Collection, Special Collections, Portland State University Library

Planned Parenthood Association of Oregon, Archived Materials, Planned Parenthood of the Columbia-Willamette

Newspapers and Periodicals:

Catholic Sentinel (Portland, OR)

Journal of the American Medical Women's Association (New York, NY)

Oregon Journal (Portland, OR)

Oregonian (Portland, OR)

Portland Reporter (Portland, OR) 
Published Primary Sources:

Articles:

Avery, Curtis. "Toward and Understanding of Sex Education in Oregon." The Coordinator 5, No. 1 (September 1956): 1-10.

Brodie, Jessie Laird. "Family Planning in 1968 - Basic Human Right.” Journal of the American Medical Women's Association 24, No. 5 (May 1969): 400-406.

--------"Medical and Social Problems of Sickle Cell Anemia: The Patient and the Bearer of the Trait." Journal of the American Medical Women's Association 30, No. 11 (November 1975): 453-455.

-------“Sickle Cell Anemia-The Disease of Challenge." Journal of the American Medical Women's Association 27, No. 8 (August 1972): 411-415.

"Where Oregon is Today in Family Planning." Northwest Medicine 66, No. 1 (November 1967): 1036-1039.

D’Antonio, W.V. “The Bishop's Statement: Birth Control and Coercion.” The Commonweal (December 2, 1966): 247-249.

Lee, Margie. "Sex in Context: The Psycho-Social Focus of E.C. Brown Trust Research, 1949-1959." The Family Life Coordinator 8, No. 2 (December 1959): 19-33. Mahn, Erna H. "Septicotoxemia Cause by Bacillus Perfringens: Report of 75 Cases Secondary to Septic Abortions (1948-1952)." Journal of the American Medical Women's Association 9, No. 1 (January 1954): 2-6.

Riemer, John J. “An Interview with Lester A. Kirkendall.” Alternative Lifestyles 2, No. 1 (February 1979): 101-119. 
Womble, Dale L. “The E.C. Brown Foundation: A Pioneering Enterprise in Family Life and Sex Education." Family Relations 32, No. 2 (April 1983): 173-178.

Urofsky, Melvin and Paul Finkelman, Eds. Documents of American Constitutional and Legal History, Volume II: From the Age of Industrialization to the Present. New York and Oxford: Oxford University Press, 2002.

Books:

Barnett, Ruth. They Weep on My Doorstep. Beaverton, OR: Halo Publishers, 1969.

Brodie, Jessie Laird. "Dr. Jessie”: The Odyssey of a Woman Physician. Portland:

Carolina Pacific Publishing, 1991.

Cline, David P. Creating Choice: A Community Responds to the need for Abortion and Birth Control, 1961-1975. New York: Palgrave MacMillan, 2006.

Katz, Esther, Ed., Cathy Moran Hajo and Peter C. Engelman, Asst. Eds. The Selected Papers of Margaret Sanger, Volume 1: The Woman Rebel, 1900-1928. Urbana and Chicago: University of Illinois Press, 2003.

\section{SECONDARY SOURCES}

Articles:

Guy, Donna. "The Politics of Pan-American Cooperation: Maternalist Feminism and the Child Rights Movement, 1913-1960," in White Slavery and Mothers Alive and Dead: The Troubled Meeting of Sex, Gender, Public Health, and Progress in Latin America. Lincoln and London: University of Nebraska Press, 2000, 54-71. 
Jensen, Kimberly. "Revolutions in the Machinery: Oregon Women and Citizenship in Sesquicentennial Perspective." Oregon Historical Quarterly Fall 2009: 336. Academic OneFile. Accessed April 7, 2012.

http://go.galegroup.com.proxy.lib.pdx.edu/ps/i.do?id=GALE\%7CA208131432\&v $=2.1 \& u=s 1185784 \& \mathrm{it}=\mathrm{r} \& \mathrm{p}=\mathrm{AONE} \& \mathrm{sw}=\mathrm{w}$

Ladd-Taylor, Molly. "Eugenics, Sterilisation and Modern Marriage in the USA: The Strange Career of Paul Popenoe." Gender \& History 13, No. 2 (August 2001): 289-327.

------- "Toward Defining Maternalism in U.S. History." Journal of Women's History 5, No. 2 (Fall 1993): 100-113.

Largent, Mark A. “'The Greatest Curse of the Race': Eugenic Sterilization in Oregon, 1909-1983.” Oregon Historical Quarterly 103, No. 2 (2002): 188-209.

Reid, Clarice and Griffin Rodgers. "Sickle Cell Disease: Demystifying the Beginnings," in Renaissance of Sickle Cell Disease Research in the Genome Era, edited by Betty Pace. London: Imperial College Press, 2007, 1-12.

Rupp, Leila J. “Constructing Internationalism: The Case of Transnational Women's Organizations, 1888-1945.” The American Historical Review 99, No. 5 (December 1994): 1571-1600.

\section{Books:}

Briggs, Laura. Reproducing Empire: Race, Sex, Science, and U.S. Imperialism in Puerto Rico. Berkeley, Los Angeles, London: University of California Press, 2002. 
Chesler, Ellen. Woman of Valor: Margaret Sanger and the Birth Control Movement in America. New York: Anchor Books, 1992.

Choy, Catherine Ceniza. Empire of Care: Nursing and Migration in Filipino American History. Durham and London: Duke University Press, 2003.

Davis, Tom. Sacred Work: Planned Parenthood and its Clergy Alliances. New Brunswick, New Jersey, and London: Rutgers University Press, 2006.

Donaldson, Peter J. Nature Against Us: The United States and the World Population Crisis, 1965-1980. Chapel Hill and London: The University of North Carolina Press, 1990.

Dowbiggin, Ian. The Sterilization Movement and Global Fertility in the Twentieth Century. New York: Oxford University Press, 2008.

Gordly, Avel Louise with Patricia A. Schechter. Remembering the Power of Words: The Life of an Oregon Activist, Legislator, and Community Leader. Corvallis: Oregon State University Press, 2011.

Gordon, Linda. The Moral Property of Women: A History of Birth Control Politics in America. Urbana and Chicago: University of Illinois Press, 2002.

Hajo, Cathy Moran. Birth Control on Main Street: Organizing Clinics in the United States, 1916-1939. Urbana, Chicago, and Springfield: University of Chicago Press, 2010.

Jensen, Kimberly and Erika Kuhlman, Eds. Women and Transnational Activism in Historical Perspective. Dordrecht: Republic of Letters, 2010. 
Johnson, John W. Griswold v. Connecticut: Birth Control and the Constitutional Right of Privacy. Lawrence, KS: University Press of Kansas, 2005.

Kline, Wendy. Building a Better Race: Gender, Sexuality, and Eugenics from the Turn of the Century to the Baby Boom. Berkeley, Los Angeles, London: University of California Press, 2001.

Ladd-Taylor, Molly. Mother-Work: Women, Child Welfare, and the State, 1890-1930. Urbana and Chicago: University of Illinois Press, 1994.

Largent, Mark A. Breeding Contempt: The History of Coerced Sterilization in the United States. New Brunswick, NJ and London: Rutgers University Press, 2008. Leavitt, Judith Walzer. Women and Health in America: Historical Readings, Second Edition. Madison: University of Wisconsin Press, 1999.

McDonagh, Eileen. The Motherless State: Women's Political Leadership and American Democracy. Chicago and London: The University of Chicago Press, 2009. More, Ellen Singer. Restoring the Balance: Women Physicians and the Profession of Medicine, 1850-1995. Cambridge: Harvard University Press, 1999.

Pascoe, Peggy. What Comes Naturally: Miscegenation Law and the Making of Race in America. New York: Oxford University Press, 2009.

Reagan, Leslie J. When Abortion was a Crime: Women, Medicine, and Law in the United States, 1867-1973. Berkeley and Los Angeles: University of California Press, 1997.

Roberts, Betty with Gail Wells. With Grit and By Grace: Breaking Trails in Politics and Law, A Memoir. Corvallis: Oregon State University Press, 2008. 
Rosen, Christine. Preaching Eugenics: Religious Leaders and the American Eugenics Movement. New York: Oxford University Press, 2004.

Schoen, Johanna. Choice \& Coercion: Birth Control, Sterilization, and Abortion in Public Health and Welfare. Chapel Hill and London: University of North Carolina Press, 2005.

Solinger, Rickie. The Abortionist: A Woman Against the Law. Berkeley and Los Angeles: University of California Press, 1994.

-----Pregnancy and Power: A Short History of Reproductive Politics in America. New York and London: New York University Press, 2005.

-----Wake Up Little Susie: Single Pregnancy and Race Before Roe v. Wade. New York and London: Routledge, 1992.

Stepan, Nancy Leys. "The Hour of Eugenics": Race, Gender, and Nation in Latin America. Ithaca and London: Cornell University Press, 1991.

Tone, Andrea. Devices and Desires: A History of Contraceptives in America. New York: Hill and Wang, 2001.

Websites:

"What is Humanism: Definitions of Humanism." American Humanist Association: Good Without a God. Accessed August 25, 2011. http://www.americanhumanist.org/AHA/Frequently_Asked_Questions 
"About AMWA." AMWA-American Medical Women's Association: The Vision and Voice of Women in Medicine Since 1915. Accessed February 7, 2012. http://www.amwa-doc.org/page3-3/AboutUs

"About CARE." CARE: Defending Dignity. Fighting Poverty. Accessed February 15, 2012. http://www.care.org/about/index.asp

"Our Mission, Vision, and Values." IIRR: International Institute of Rural Reconstruction. Accessed March 20, 2012. http://www.iirr.org/index.php/aboutus/main-content/our_mission/

“About Us.” Oxfam International. Accessed March 20, 2012. http://www.oxfam.org/en/about

"Eisenstadt v. Baird." The Oyez Project at IIT Chicago-Kent College of Law. Accessed August 25, 2011. http://www.oyez.org/cases/1970-1979/1971/1971_70_17

"Griswold v. Connecticut." The Oyez Project at IIT Chicago-Kent College of Law. Accessed March 15, 2012. http://www.oyez.org/cases/1960-1969/1964/1964_496 "Roe v. Wade." The Oyez Project at IIT Chicago-Kent College of Law. Accessed March 29, 2012. http://www.oyez.org/cases/1970-1979/1971/1971_70_18

"About Us: History." Pathfinder International: A Global Leader in Reproductive Health. Accessed March 17, 2012. http://www.pathfind.org/site/PageServer?pagename=About_History “The Real History of Your Right to Birth Control.” Pro Choice League, 2006-2009. Accessed August 25, 2011. http://prochoiceleague.org/history.html 
"Who We Are." Hôpital Albert Schweitzer Haiti: Saving Lives, Changing Lives For More Than 50 Years. Accessed March 17, 2012. http://www.hashaiti.org/History "History." SIECUS: Sexuality Information and Education Council of the United States. Accessed March 18, 2012. http://www.siecus.org/index.cfm?fuseaction=Page.viewPage\&pageId=493\&paren $\mathrm{tID}=472$

"Soroptimist of Portland OR." soroptimistpdx.org. Accessed February 19, 2012. http://www.soroptimistpdx.org/index.

"Human Growth (1947)." The U of O Channel, University of Oregon, 2010. Accessed April 8, 2012, http://media.uoregon.edu/channel/2012/04/03/human-growth-1947/ 